\title{
Valanginian to Barremian benthic foraminifera from ODP Site 766 (Leg 123, Indian Ocean)
}

\author{
Ann E. L. Holbourn and Michael A. Kaminski \\ Research School of Geological and Geophysical Sciences Birkbeck College and University College London, \\ Gower Street, London WCIE 6BT, U.K.
}

\begin{abstract}
A Valanginian to Barremian bathyal foraminiferal assemblage (118 taxa belonging to 51 genera) is documented from ODP Site 766, drilled near the foot of the Exmouth Plateau off northwest Australia. The majority of taxa are cosmopolitan species previously described from the boreal assemblages of northern Europe and the northern margins of the Tethys, but 32 taxa could not be assigned to previously described species and are left in open nomenclature. The chronostratigraphy of this section is based upon nannofossils, palynomorphs, and radiolarians. The foraminiferal succession is divided into four assemblages based on the first and last occurrences of characteristic benthic foraminifera: 1) An upper Valanginian Lenticulina ouachensis - Textularia bettenstaedti assemblage with Ammodiscus tenuissimus, Bulbobaculites sp., and Aaptotoichus clavellatus. The last occurrences of these taxa are observed near the transition between the Valanginian and Hauterivian. 2) A lower Hauterivian assemblage is characterized by Lenticulina heiermanni and Saracenaria forticosta. 3) An upper Hauterivian assemblage contains Planularia crepidularis, Patellina subcretacea, and Reinholdella hofkeri. A major faunal discontinuity is observed at the top of this assemblage between Cores 766A-32R and 766A-30R, probably associated with a depositional gap between the late Hauterivian and the Barremian. 4) The overlying Barremian assemblage is characterized by Gavelinella barremiana, Glomospira spp., and Pseudogaudryinella sp. This record enables long-distance comparisons of the stratigraphic ranges of benthic foraminiferal species in the austral bioprovince with their reported ranges in the North Atlantic region and the northern Tethys. Although the assemblages at Site 766 consist of ca. 74\% cosmopolitan species, they differ from Tethyan assemblages in the rarity or absence of index taxa such as Praedorothia spp., Lenticulina nodosa and $L$. eichenbergi, as well as ornamented, palmate morphotypes such as Citharina spp., Flabellina spp., and Frondicularia spp. They differ from the typical boreal assemblages by the lack of diverse agglutinated taxa. As a result, benthic foraminiferal zonations established for the Lower Cretaceous of the northern Tethys and Tethyan DSDP sites could not be applied at Site 766. Taxonomic and biostratigraphic differences at Site 766 support the existence of a taxonomically distinct Early Cretaceous austral bioprovince.
\end{abstract}

\section{INTRODUCTION}

The biogeographic distribution of various marine organisms in Lower Cretaceous sequences has enabled paleontologists to recognize the existence of two main bioprovinces during Early Cretaceous time: a boreal bioprovince in high northern latitudes and a Tethyan bioprovince in low tropical latitudes. The presence of a third main bioprovince in the southern hemisphere - the austral bioprovince, which was the southern hemisphere equivalent to the cool boreal bioprovince - is, however, rarely mentioned in the literature as research has traditionally focused on boreal and tropical assemblages. For a long time, the Cretaceous foraminiferal microfaunas from Australia and New Zealand were viewed as unusual and endemic. Even now, relatively little is known about the microfaunas from the austral bioprovince and about their relationship to those of the other two bioprovinces during the Early Cretaceous.

The recovery of Lower Cretaceous sedimentary sequences from ODP sites in the Indian Ocean has, fortunately, provided new material for studying the distribution of foraminifera in the high southern latitudes. At ODP Site 766 diverse, well-preserved, bathyal assemblages have been recovered from sediments as old as Valanginian, in contrast to the predominantly marginal assemblages previously described from epeiric basins in Australia and the Indian Ocean. The foraminifera from ODP Site 766, therefore, offer a unique insight into the composition of deep-water benthic assemblages during the Early Cretaceous. These assemblages also provide the opportunity to retrace the evolution of one of the oldest continental margins in the world from its early rifting phase early in the Cretaceous, when the supercontinent Gondwana fragmented and the Indian Ocean started to open, to its mature position in the Albian at the edge of a vast ocean.

The main objective of this work is to conduct a detailed taxonomic and biostratigraphic survey of the lesser-known Valanginian to Barremian benthic foraminifera at Site 766 and to compare them with better-documented assemblages from the Tethyan and boreal bioprovinces. Benthic foraminifera are particularly useful for stratigraphy during this interval because planktonic species are absent. They are also important for paleogeographic and paleoceanographic reconstructions and for worldwide stratigraphic correlations (e.g. Bartenstein 1979).

\section{PREVIOUS WORK}

Taxonomy and distribution of southern hemisphere benthic foraminifera

A detailed study of Aptian-Albian benthic foraminifera at ODP Site 766 was carried out by Haig (1992). The Valanginian-Barremian assemblages at this site were examined on board ship: eight species were mentioned in the ODP Site 766 Site report (Ludden and Gradstein et al. 1990). No further work has followed these initial investigations.

The taxonomy and paleoecology of Lower Cretaceous benthic assemblages from high southern latitudes have been studied by several authors, mainly over the past 30 years. Crespin $(1944,1953$, 1963) described the Aptian-Albian assemblages from epicontinental seas of mainland Australia. Espitalié and Sigal (1963) compiled 
a detailed taxonomic and stratigraphic study of foraminifera from Upper Jurassic and Lower Cretaceous deposits of the Majunga Basin (Madagascar) that recognized 189 species, 54 of them new. Ludbrook (1966) documented the foraminiferal assemblages from the Great Artesian Basin. Global distribution patterns were investigated by Sigal et al. (1970), who showed similarities between foraminifera from Upper Jurassic and Lower Cretaceous Gondwana continental margin deposits of Madagascar, India and Chile.

In a series of papers, Scheibnerová (1971a, 1971b, 1972, 1974a, 1974b, 1976, 1977) described Lower Cretaceous assemblages from the Great Artesian Basin and from DSDP Sites in the Indian Ocean. Scheibnerová recognized the existence of an austral biogeoprovince in the southern hemisphere. According to Scheibnerová, austral assemblages (in common with cool boreal assemblages) typically lacked planktonic species and were dominated by agglutinated foraminifera and small simply ornamented calcareous forms. Scheibnerová $(1973,1978)$ proposed that the austral biogeoprovince, that included Australia, the epicontinental seas of Gondwana and the Cretaceous southern oceans, supported a distinctive cool-water microfauna and that episodic south-north migrations caused similarities between austral and boreal faunas. Lambert and Scheibnerová (1974) compared Albian foraminifera from Zululand (South Africa) and the Great Artesian Basin (Australia) and concluded that they represented a typical, cool-water, austral fauna from shallow environments. Scheibnerová (1974b) described the Aptian-Albian benthic foraminifera from DSDP Sites 259, 260 and 263 and compared them with coeval assemblages from India, Australia and South Africa. Kuznetsova (1974) interpreted the predominantly agglutinated assemblage from the Upper Jurassic and Lower Cretaceous of ODP Site 261 in the eastern Indian Ocean as of deep-water origin, while Scheibnerová (1977) ascribed to the same assemblage a shallow-water origin in a cool, stagnant basin, despite its location on Oxfordian oceanic crust.

Bartenstein (1974a, 1977, 1978, 1979) investigated the stratigraphic range and distribution of Lenticulina nodosa (and subspecies) and other index species in Lower Cretaceous sediments worldwide, and Aubert and Bartenstein (1976) extended the range and distribution of $L$. nodosa and related species throughout the north and south temperate realms and the Tethyan realm. Bartenstein (1974b) also documented the "primitive" agglutinated assemblages from Upper Jurassic and Lower Cretaceous deposits at ODP Sites 259 and 261 in the eastern Indian Ocean.

Haig (1979) distinguished three main benthic associations, differentially distributed in tropical and cool-temperate climatic belts from the Barremian to the Cenomanian: 1) the neritic Ammobaculites Association dominated by organically cemented forms was extensively developed in epicontinental seas of cool-temperate belts; 2) the predominantly bathyal Marssonella Association dominated by calcareous forms lacked "larger" foraminifera and was characteristic of continental slope environments above the CCD (carbonate compensation depth); and 3) the Recurvoides Association which was found in abyssal areas beneath the CCD showed no change in tropical and cool-temperate belts. Haig (1980, 1982) described 54 textulariine species and 143 milioline and rotaliine species from the Aptian-Albian of Queensland and assigned the foraminifera to the Ammobaculites and Marssonella Associations. Haig (1981) also recorded diverse textulariine-rotaliine assemblages with many cosmopolitan forms from the Aptian-Albian of Papua New Guinea, which he attributed to the Marssonella Association. Moullade and Guérin (1982) showed that provincialism was much less marked than previously thought in southern latitudes and that foraminiferal evidence from DSDP Sites and
Tethyan locations supported the existence of relatively deep connections between the south and central Atlantic Oceans in the middle Albian. Haig and Lynch (1993) related changes in foraminiferal biofacies during the late early Albian (from low diversity agglutinated assemblages to high diversity calcareous assemblages) to a transgressive pulse over northeastern Australia.

Riccardi (1988) listed Lower Cretaceous foraminifera recovered from the Austral Basin of southern Patagonia and from the Andean Basin. These assemblages were dominated by benthic species that showed varying degrees of endemism. Riegraf (1989) studied Valanginian-Hauterivian benthic assemblages at ODP Site 249 in the Indian Ocean, southwest of Madagascar; the 42 recorded species comprised mainly nodosariids, typical of shelf environments which showed a strong cosmopolitan influence. Riegraf and Luterbacher (1989a) presented a biostratigraphical, taxonomical and paleoecological overview of Lower Cretaceous foraminifera from DSDP Sites in the Atlantic, Indian and Pacific Oceans (Legs 1-80). Kaminski et al. (1992) and Kaminski and Geroch (1992) studied deep-water benthic assemblages from the Tithonian to Aptian at ODP Sites 765 and 261 on the Argo Abyssal Plain in the Indian Ocean. These authors found that the predominantly agglutinated assemblages included many cosmopolitan species known from other sub-CCD environments (Carpathians, North Atlantic) but were taxonomically more diverse than any previously described deep-water assemblages.

\section{Review of zonal schemes for the Lower Cretaceous}

The biostratigraphy of Lower Cretaceous benthic foraminifera has been studied by a number of authors. The work of Bartenstein and co-workers on the benthic foraminifera of the Saxony Basin has led to a local biostratigraphic scheme for NW Germany (Bartenstein and Bettenstaedt 1962). This zonation was based on the stratigraphic succession of 75 foraminifera and 12 ostracod species in the middle Valanginian to lowermost Cenomanian of Saxony. The stratigraphic ranges of benthic foraminifera were calibrated to the standard ammonite zones. The zonation of NW Germany has been later refined in numerous publications by Bartenstein and co-workers, and formed the basis of a proposal for a general biostratigraphic zonation for the worldwide Lower Cretaceous using cosmopolitan species (Bartenstein 1979). This worldwide zonation was based on comparing the stratigraphic ranges of species on both sides of the North Atlantic. Bartenstein used the study of Ascoli (1976) as a standard reference for the Canadian offshore wells. In this zonal scheme, Bartenstein extended the stratigraphic ranges of some of the NW German species to older (Berriasian or Tithonian) horizons, but the first occurrences of many forms were still recorded with a question mark. The upper limits of the stratigraphic ranges remain largely unchanged from the earlier study.

The stratigraphic ranges of 152 boreal, shallow water Cretaceous foraminifera from southeast England were reported by Hart et al. (1989). Data for the Berriasian to Barremian are based mainly on studies of the section at Speeton, NE England. Hart et al. did not erect a formal zonation for the Lower Cretaceous, but provided a range chart. This work on the Lower Cretaceous benthic foraminiferal zonations can be extended by including the deeper boreal assemblages of the Viking and Central Grabens of the North Sea (King et al. 1989).

Moullade (1984) reviewed the importance of small, cosmopolitan, benthic foraminifera from the Oxfordian to the Cenomanian for stratigraphy, paleoecology and paleogeography and proposed a formal zonation for the Upper Jurassic-Lower Cretaceous based on benthic foraminifera. This was the first formal zonation of the 


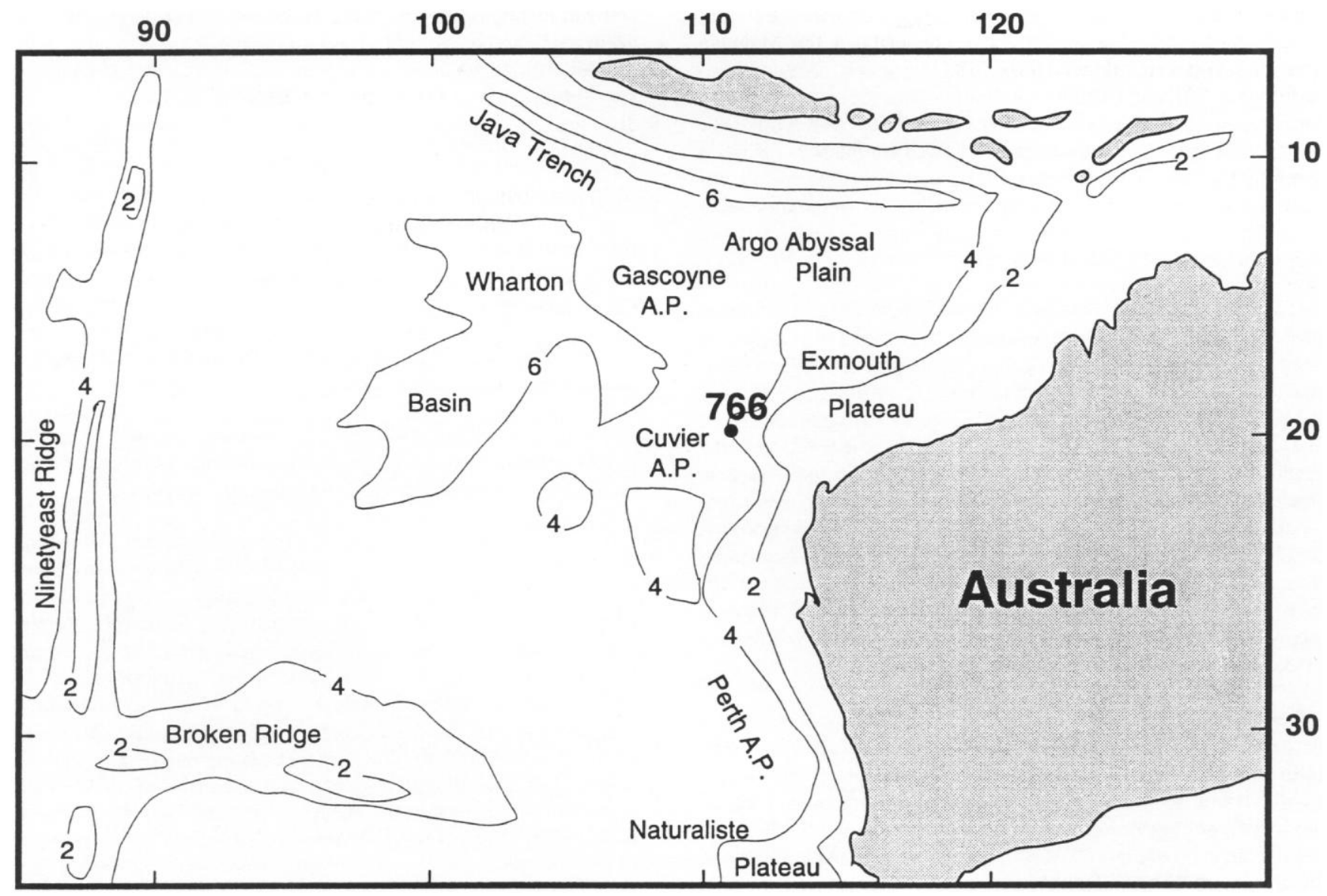

TEXT-FIGURE 1

Location of Site 766 on the lower Exmouth Plateau (redrawn after Ludden, Gradstein et al. 1990). Countours in thousands of meters

northern Tethyan margin, and was based to a large extent on comparison of North Atlantic low-latitude DSDP sites with the Vocontian Trough. Moullade (1974) had previously developed a Lower Cretaceous zonal scheme for the pelagic facies of the Mediterranean Province based on the Vocontian Basin and several other stratoypes and had also proposed (1979) a zonation for the Valanginian in southeastern France based on benthic foraminifera which was correlated with ammonites. A zonal scheme for the Tithonian to Cenomanian of the northern Tethyan margin, published by Weidich (1990), was based on the occurrence of over 400 foraminiferal species from the Northern Calcareous Alps in Bavaria and Austria. This monograph provides the most complete taxonomic data set for the northern Tethys. Weidich's biostratigraphic scheme subdivided the Lower Cretaceous into 10 zones based on first occurrences or acmes of primarily calcareous benthic foraminifera. For the interval of interest for this study, Weidich recognised only three zones, in contrast to the 10 zones defined by Moullade. However, Weidich's zonal scheme is only tentatively correlated to the standard chronostratigraphy (therefore zonal boundaries are indicated by dashed lines), and further calibration of Weidich's samples by means of planktonic microfossils is needed to refine the age of his zones.

Riegraf and Luterbacher (1989a) studied 22 low latitude sites situated in the northern hemisphere, but three sites from higher southern latitudes were also investigated: Sites 249 and 261 in the Indian Ocean and Site 330 in the Atlantic Ocean. These authors devised a Lower Cretaceous benthic foraminiferal zonation that subdivided the Berriasian to Cenomanian into six zones, based on the first occurrences of certain taxa. The authors also reported the stratigraphic ranges of 31 cosmopolitan deep-sea species in both deep sea and continental margin sequences. They extended the known stratigraphic range of several other deep-sea taxa into older levels. Among them is the species Gavelinella barremiana, which was reported from the base of Hauterivian and is the nominate taxon for their Hauterivian zone. Moullade (pers. comm., 1994) has suggested, however, that the form reported by Riegraf and Luterbacher may be a precursor of $G$. barremiana, which is known to have ancestors with FO at the Hauterivian-Barremian boundary (cf. G. aff. barremiana Moullade 1966, p. 73).

\section{LOCATION AND GEOLOGICAL SETTING}

ODP Leg 123, Site 766 was drilled at latitude $19^{\circ} 55.92^{\prime} \mathrm{S}$ and longitude $110^{\circ} 27.24^{\prime} \mathrm{E}$ at the foot of the Exmouth Plateau, off northwestern Australia (text-fig. 1). This site is located on an ancient continental margin; it formed part of an extensive continental rift zone during the Early Cretaceous when the supercontinent Gondwana fragmented and the Indian Ocean started to open. Approximately $300 \mathrm{~m}$ of Valanginian to Albian sediments were recovered at Site 766 . The chronostratigraphy based on magnetostratigraphy, palynomorphs, radiolarians and benthic foraminifera was compiled by Kaminski et al. (1992). The Lower Cretaceous chronostratigraphy of Hole $766 \mathrm{~A}$ is shown in text-figure 2 . The 
Valanginian to Barremian interval (Sections 123-766A-26R-1 to 123-766A-49R-4) consists of approximately $250 \mathrm{~m}$ dark greenish gray siliciclastics, which have been divided into two main lithological subunits (IIIA and IIIB). A prominent seismic reflector marks the boundary between subunits IIIA and IIIB where the lithology changes from claystones (above) to sandstones and siltstones (below). This unconformable surface, located at $307 \mathrm{~m}$ below the sea floor, is characterized by onlap above and erosional truncation below and represents a major unconformity between the two subunits (Ludden, Gradstein et al. 1990).

The oldest subunit IIIB (Sections 123-766A-32R, CC to 123-766A49R-4) thickens to the southwest and is dominated by redeposited sandstones and siltstones with a few intercalated ash layers. It has been interpreted as a prograding syn-rift sedimentary wedge, composed mainly of volcanic and shallow marine grains derived from the outer Exmouth Plateau which had become elevated to the southwest due to thermal uplift of the rifting margin (Ludden, Gradstein et al. 1990). This sedimentary sequence has no equivalent on the Exmouth Plateau where it coincides with an unconformity. Buffler et al. (1992) proposed that it was deposited when the Cuvier Ocean basin opened and "Greater India" drifted past Site 766 in the Valanginian-Hauterivian. High TOC values to about $1.6 \mathrm{wt} \%$ were recorded for subunit IIIB and Rock-Eval pyrolysis indicated a terrestrial origin for the organic matter.

Subunit IIIA (Sections 123-766A-26R-1 to 123-766A-32R, CC) is characterized by bioturbated claystones with abundant glauconitic grains and radiolarians, which suggest a lower depositional energy, possibly in a deeper and/or more stable environment. Thermal subsidence of the margin coupled with a sea-level rise and a major ridge jump probably cut off the supply of coarse clastics and led to the abandonment of the prograding wedge system (subunit IIIB) and to the deposition of a more hemipelagic sequence (Subunit IIIA) during the Barremian (Buffler et al. 1992). The characteristic TOC values, which are near $1 \mathrm{wt} \%$ for the claystones, are lower than in the basal subunit IIIB.

From backtracking, sedimentation appears to have started at depths of about $800 \mathrm{~m}$ and the site probably remained near or above CCD level throughout the Early Cretaceous; the calculated sedimentation rates of $60 \mathrm{~m} / \mathrm{my}$ are high for subunit IIIB, but decrease to $10 \mathrm{~m} / \mathrm{m}$.y. for subunit IIIA (Ludden, Gradstein et al. 1990).

\section{METHODS}

Fifty-three samples $(20 \mathrm{cc})$ from Cores $49 \mathrm{R}-04$ to $26 \mathrm{R}-01$ were processed by repeated drying and washing in $1 \%$ Calgon solution. The washed residues were randomly divided into fractions with the help of a sample splitter; the fractions were then sieved $(>250 \mathrm{~mm}$, $>125 \mathrm{~mm}$ and $>63 \mathrm{~mm}$ ) and each picked for microfossils. When fossil abundance allowed, a minimum of 300 foraminifera were picked per sample as well as other microfossils. The picked specimens were then sorted on cardboard slides for identification. These are housed in the Micropaleontology collections of University College London.

Taxonomic comparisons were made with paratypes and holotypes from Early Cretaceous foraminiferal collections at the Senckenberg Museum in Frankfurt (Bartenstein and Brand 1951; Bartenstein and Kaever 1973) and at the Institute for Palaeontology and Historical Geology in Munich (Weidich 1990). Site 766 assemblages were also compared with coeval, Tethyan and boreal assemblages from Atlantic ODP Sites and continental Europe and with high latitude, southern assemblage from Indian Ocean ODP Sites. Scanning electron micrographs were made on a Zeiss-DSM-940 SEM at the Micropaleontology Unit of University College London.

\section{RESULTS}

Calcareous foraminifera dominate the assemblages at Site 766 , but significant numbers of agglutinated forms are present at the lower and upper portions of the sequence (core sections 766A-49R-03 to $-43 R-05$ and core sections $766 \mathrm{~A}-30 \mathrm{R}-02$ to $-26 \mathrm{R}-01$ ). The microfossil assemblages in the basal part of the succession (core sections 766A-49R-03 to -48R-06) are numerically dominated by radiolarians. In general, preservation is moderate to good in most samples, except for a few diagenetically altered intervals. The benthic foraminiferal data are given in table 1 . The stratigraphic ranges of selected benthic foraminifera are given in text-figure 3 .

The foraminiferal succession can be subdivided into four assemblages based on changes in the composition of dominant taxa and on occurrences of stratigraphically important species.

1) Lenticulina ouachensis - Textularia bettenstaedti assemblage (core sections 766A-49R-03 to -43R-05): This upper Valanginianlower Hauterivian mixed calcareous/agglutinated assemblage is characterized by Lenticulina ouachensis, Textularia bettenstaedti, Bulbobaculites sp. 1, Ammodiscus tenuissimus, Aaptotoichus clavellatus, Rhizammina spp. and Haplophragmoides spp. Diversity is relatively high with up to 49 species per sample. Foraminiferal abundances are low only at the base of the succession (Cores 766A-49R-03 to -48R-06). Fluctuating numbers of coarsely agglutinated Bulbobaculites sp. 1 and Ammobaculites sp. 1 are noted between core sections $766 \mathrm{~A}-47 \mathrm{R}-01$ and $-44 \mathrm{R}-01$ and point to the coarse clastic origin of lithologic subunit IIIB. The upper part of this assemblage is marked by the disappearance of agglutinated taxa, probably indicating a change to more open oceanic conditions.

2) Lenticulina heiermanni - Saracenaria forticosta assemblage (core sections 766A-43R-04 to -40R-03): This is andiagnostic lower Hauterivian interval assemblage dominated by nodosariids. This typically bathyal assemblage is characterized by Lenticulina heiermanni, Saracenaria forticosta, Globulina spp., Oolina spp. and diverse nodosariids. Both diversity (maximum number of species is 28) and abundance decrease compared with the previous assemblage, and samples in core sections $766 \mathrm{~A}-42 \mathrm{R}$ and $-41 \mathrm{R}$ are barren.

3) Planularia crepidularis - Patellina subcretacea assemblage (core sections 766A-40R-02 to -32R-02): The base of this upper Hauterivian assemblage is marked by the FO of Saracenaria valanginiana and Reinholdella hofkeri and by a massive influx of Patellina subcretacea. The foraminiferal abundances increase at the base of the interval then fluctuate markedly from core section 766A-37R-03 to the top. Diversities remain moderate (with up to 28 species per sample). Agglutinated foraminifera are also absent from this assemblage. At four levels (core sections 766A-40R-02, $-38 \mathrm{R}-02$ to $-37 \mathrm{R}-03,-35 \mathrm{R}-01$, and $-32 \mathrm{R}-05$ ), the assemblages become strongly dominated by Patellina subcretacea and to a lesser extent by Reinholdella hofkeri. Highly fluctuating numbers of Patellina subcretacea are found in lithologic subunit IIIB from core sections 766A-45R-05 to 766A-32R-05.

4) Gavelinella barremiana - Pseudogaudryinella sp. 1 assemblage (core sections 766A-30R-04 to- 26R-02): The base of this Barremian assemblage is marked by a faunal turnover corresponding to a major lithological change above an unconformity. The base of the assemblage is characterized by the LO of Patellina subcretacea and the FOs of Saracenaria spinosa, Lenticulina 


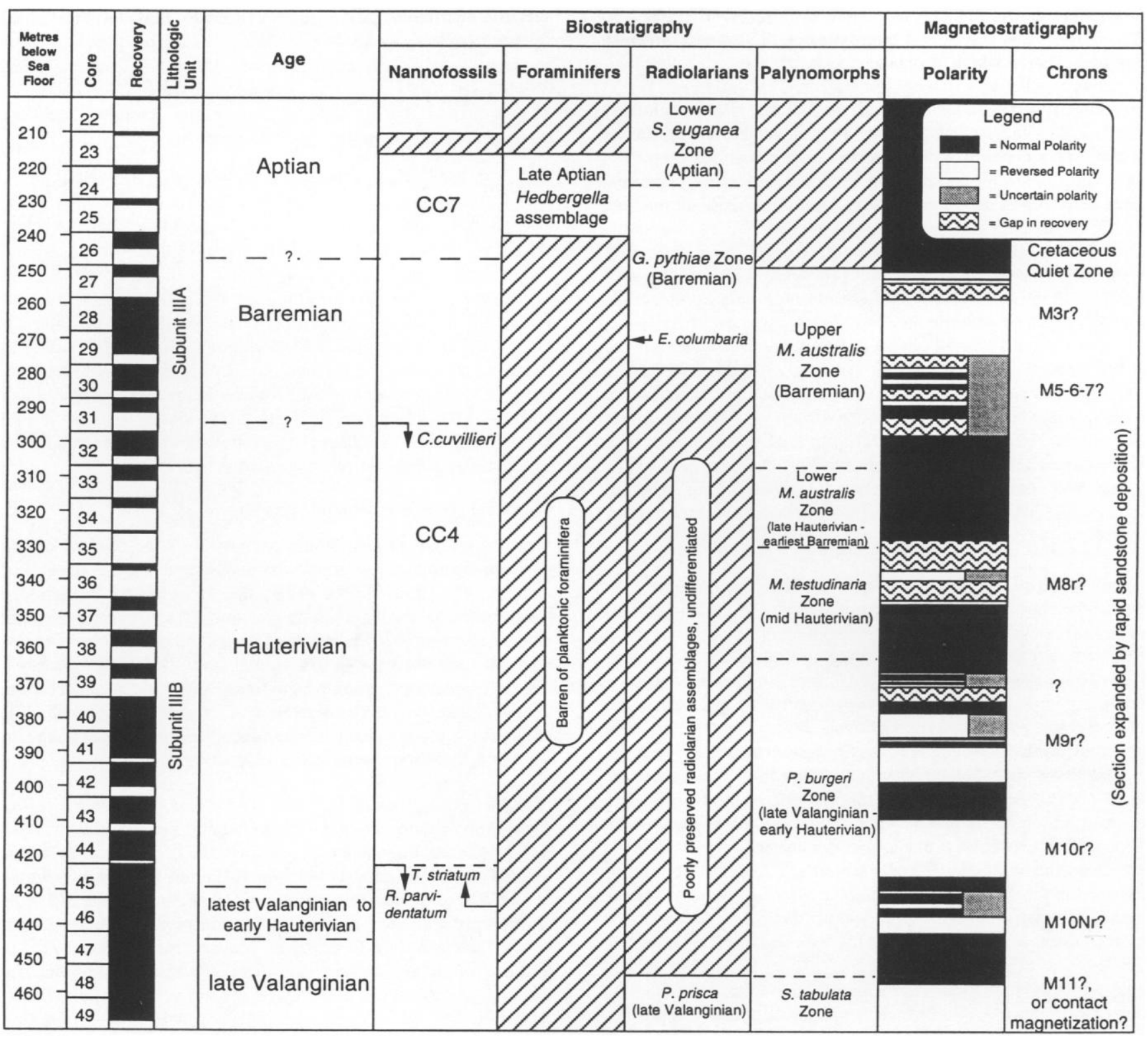

\section{TEXT-FIGURE 2}

Chronostratigraphy of the Lower Cretaceous of ODP Hole 766, based on calcareous nannofossil, planktonic foraminiferal, radiolarian and palynological biostratigraphy and magnetostratigraphy. Nannofossil zones follow the zonation of Sissingh (1977). Modified from the Leg 123 magnetobiostratigraphic synthesis Kaminski et al. (1992).

macrodisca, Lingulina sp. 1, Glomospirella gaultina and Glomospira spp. The FOs of Gavelinella barremiana and Pseudogaudryinella sp. 1 were observed in Sample 766A-29R-03, $54-55 \mathrm{~cm}$. Diversity is very high in this interval (with up to 55 species per sample), except at the very top of the section (Cores 766A-27-03 to 26R-01) where the samples examined were virtually barren of foraminifera. Large numbers of Glomospira spp. and Pseudogaudryinella spp. are also found in the samples from this interval, indicative of a deeper water setting compared to the assemblage below.

The stratigraphic ranges of selected benthic foraminifera are shown in text-figure 3. A marked faunal change is observed at the lithostratigraphic boundary between Cores 766A-32R and $-30 \mathrm{R}$ : the calcareous species Saracenaria spinosa, and Lenticulina macrodisca make their first appearance in Core 766A-30R along with some calcareous agglutinated forms such as Pseudogaudryinella sp. 1 and Dorothia sp. 1 in Core 766A-29R. Two useful markers for the latest Hauterivian and Barremian in other parts of the world are also found in Cores 766A-30R and -29R (Gavelinella sigmoicosta and Gavelinella barremiana). This faunal change probably reflects a depositional hiatus between the late Hauterivian and Barremian represented by a major discontinuity at the boundary between lithological subunits IIIA and IIIB.

\section{DISCUSSION}

\section{Biostratigraphy}

To test whether cosmopolitan Lower Cretaceous benthic foraminifera can be used for long-distance stratigraphic correlation, we 
compared the ranges of selected commonly occurring taxa at Site 766 with their reported ranges in the published Tethyan and boreal zonations. These species are listed in table 2.

The zonal scheme of the lower Saxony Basin (Bartenstein and Bettenstaedt 1962) was based mainly on benthic foraminiferal species that are known from shallow marine sediments, such as Citharina, Epistomina and ornamented Lenticulina. Unfortunately these forms are absent or very rare at Site 766. Only 19 of the NW German index species were encountered in this study. Among these taxa, 11 occur commonly at Site 766 and may be useful for stratigraphic correlation. The worldwide zonation proposed by Bartenstein (1979) was based on comparing the stratigraphic ranges of species on both sides of the North Atlantic. Bartenstein listed 17 species in his zonation which also occur in the studied interval at Site 766 (table 2). In general, the stratigraphic ranges of species found at Site 766 coincide with their ranges reported from the northern hemisphere zonations of Bartenstein and co-workers. However, two stratigraphically important taxa (Saracenaria spinosa and Saracenaria forticosta) appear earlier at Site 766. Other forms, such as Reinholdella hofkeri and Saracenaria valanginiana, have an expanded younger stratigraphic range in comparison with NW Europe.

A total of 13 of the 37 Valanginian to Barremian benthic taxa reported by Hart et al. (1989) were found at Site 766. There are two discrepancies in the range of two species: Gavelinella barremiana which is recorded by Hart et al. in the lower Aptian, was observed at Site 766 in the Barremian, which is more in accordance with its known range. A more striking disagreement was observed in the range of Saracenaria valanginiana which according to Hart et al. is confined to the Valanginian in SE England in agreement with the original Berriasian-Valanginian range defined by Bartenstein and Brand (1951). At Site 766 it is only present in the Hauterivian. However, in the Arctic Saracenaria valanginiana is reported by Tappan (1962) to have a much later occurrence (Aptian-Albian) than its normal range in the lower latitudes. Ludbrook (1966) also described the new species Saracenaria warella from the AptianAlbian of the Great Artesian Basin, which shows resemblance to $S$. valanginiana.

Moullade (1984) subdivided the Valanginian to Barremian into nine zones. Unfortunately, this Tethyan zonation could not be applied at Site 766 because of the absence of six of the nine zonal markers. In addition Gavelinella sigmoicosta, the nominate taxon of Moullade's uppermost Hauterivian to lowermost Barremian zone, was very rare at Site 766 . Only Gavelinella barremiana was found in the proper numbers and stratigraphic position to allow correlation with Moullade's zonal scheme. A total of 63 of the species recorded by Weidich in his range charts also occur at Site 766 , which emphasizes their cosmopolitan distribution. However, most of these are stratigraphically long-ranging forms. Weidich (1990) recognised only three zones in the Valanginian-Barremian. Several of the index taxa in Weidich's zonation are also found in a similar sequence at Site 766 . We list 13 species in common that have meaningful FOs and LOs. However, there are discrepancies beween the occurrences of some taxa at Site 766 and their reported stratigraphic ranges in the Bavarian Alps. The FO of Lenticulina heiermanni was correlated with the Valanginian/Hauterivian boundary by Weidich and was used to define the base of his Hauterivian Zone 4 while Marginulinopsis bettenstaedti was reported from the Barremian to Aptian. At Site 766, these two species range upwards from the base of the recovered sediment column (upper Valanginian). The range of Saracenaria forticosta was reported by Weidich as Barremian to Aptian, but at Site 766 it occurs in the upper Valanginian to mid-Hauterivian. Additional species that occur earlier at Site 766 are Globulina prisca, Tristix excavata and Saracenaria spinosa. The LOs of Lenticulina ouachensis and Textularia bettenstaedti were observed in the Aptian of the Bavarian Alps, whereas at Site 766 their ranges are truncated, occurring in the lower Hauterivian.

Although Riegraf and Luterbacher (1989a) included observations based on Indian Ocean DSDP sites, we found that their zonal scheme and biochronology were not applicable at Site 766. Only five of the 22 Valanginian to Barremian taxa listed in Riegraf and Luterbacher's range chart were found at Site 766. These are Dentalina debilis, Marginulinopsis bettenstaedti, Lenticulina nodosa, Lenticulina quenstedti $[=L$. ouachensis according to our taxonomy] and Gavelinella barremiana. There are differences in the reported stratigraphic ranges; for example the earliest occurrence of $G$. barremiana at Site 766 is within the lower Barremian and the last occurrence of Lenticulina ouachensis is in the Hauterivian (Table 2). These observations question the validity of this zonation for the austral bioprovince.

\section{Paleoecology and Paleobiogeography}

Some of the faunal distribution patterns observed at Site 766 are useful indicators of environmental and sedimentary changes. For example, the large number of organically cemented agglutinated foraminifera at the base of the section reflects clastic substrate and/or semi-restricted basinal conditions. The occurrence of exclusively calcareous assemblages above Core 766A-44R suggests a change to more open marine conditions as the young Indian Ocean widened. The faunal changes above Cores 766A-41R and $-33 R$ most likely record changes in sedimentation patterns linked to sea-floor spreading and/or sea-level changes.

Comparison with ODP Site 249: The assemblages from Site 766 show strong similarities to the shallow shelf calcareous faunas from Site 249 in the Indian Ocean, southwest of Madagascar to which Riegraf (1989) assigned a Valanginian-Hauterivian age. In contrast to Site 766, preservation remains good throughout at Site 249, tests are strongly sculptured and agglutinated forms are virtually absent. A slight endemic bias from nearby Madagascar is also detected at Site 249 by Riegraf (1989), which is not evident at Site 766 . The assemblage differences probably reflect different depositional settings: Site 766 was located on a rapidly subsiding margin during the Early Cretaceous, whereas Site 249 remained a shallow, shelf close to the Majunga Basin and farther away from the main rifting center.

Comparison with ODP Sites 259 and 261: The assemblages from Site 766 differ from the flysch-type assemblages recovered at ODP Sites 259 and 261 in the Indian Ocean by the scarcity of agglutinated foraminifera. Scheibnerová (1977) suggested that the flyschtype assemblages at Sites 259 and 261 were a result of a combination of shallow depth, low temperature and reducing conditions after burial, leading to test dissolution, and that the assemblages did not necessarily reflect abyssal deposition, as proposed by Kuznetsova (1974) and Gradstein (1983). Scheibnerová (1977) argued that deep environments had not developed in the nascent Indian Ocean. The marked differences in the agglutinated component at ODP Sites 259 and 261 and at ODP Site 766 may indicate a steep bathymetric gradient along the rapidly collapsing margin of the ocean.

Comparison with Tethyan and boreal assemblages: A high proportion (about 74\%) of calcareous foraminifera at Site 766 are cosmopolitan species. The assemblages from Site 766 differ, 


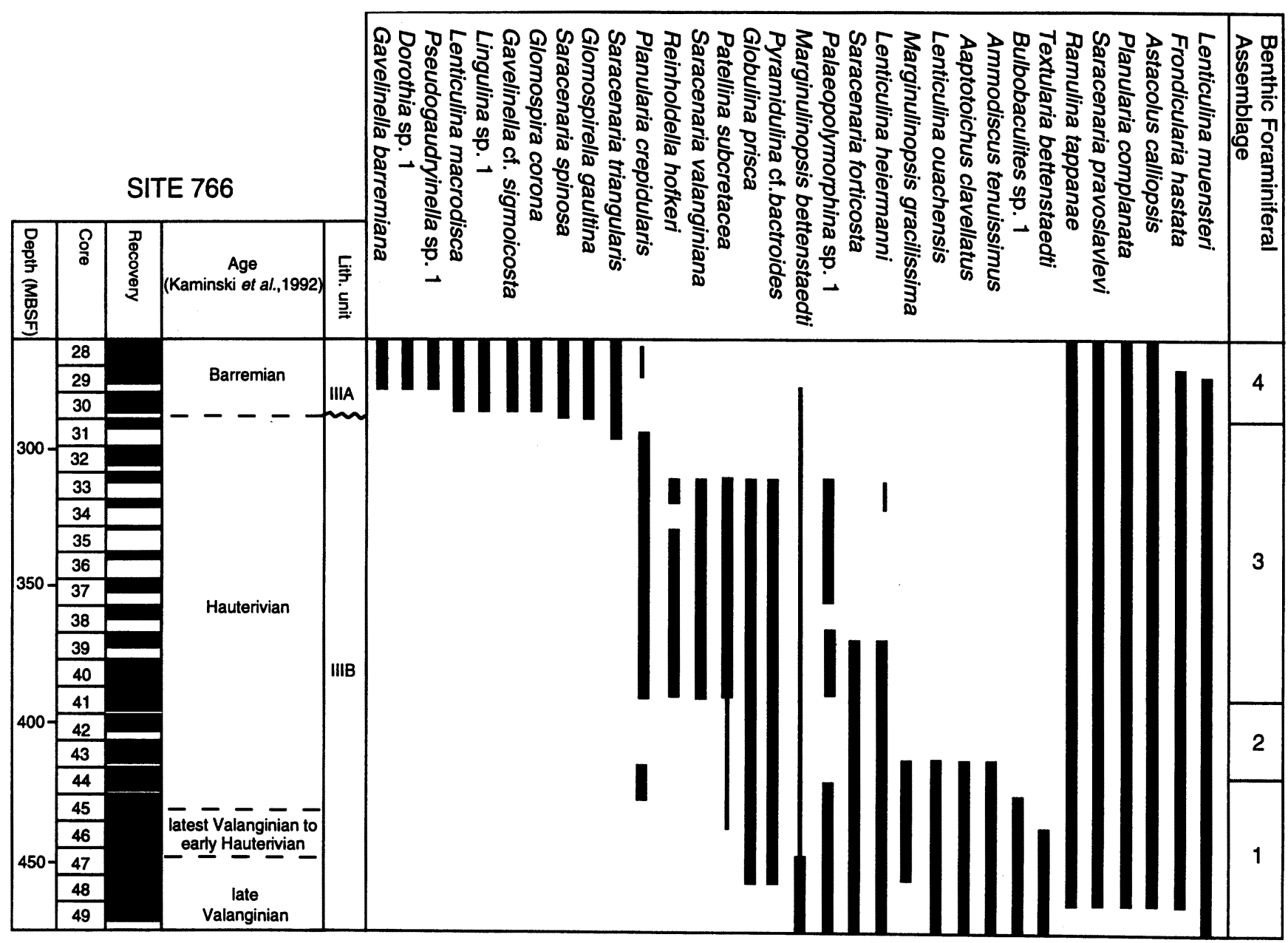

TEXT-FIGURE 3

Stratigraphic ranges of selected benthic foraminifera at Site 766.

however, from typical low latitude Tethyan assemblages by the rarity or absence of characteristic Tethyan species such as Epistomina spp., L. nodosa nodosa Reuss and $L$. eichenbergi Bartenstein and Brand and by the scarcity of large, ornamented, palmate morphotypes such as Citharina spp., Flabellina spp. and Frondicularia spp. The assemblages from Site 766 still show considerable diversity and are very different from the typical Cretaceous cold-water associations dominated by agglutinated forms known from Alaska, the Russian Platform and Canada (Tappan 1962; Azbel and Grigalis 1991; Fowler and Braun 1993). The assemblages at Site 766, in fact, most closely resemble bathyal assemblages from the northern margin of Tethys described by Weidich (1990), which he considered to be cool-water associations.

The paleolatitude of Site 766 during the Valanginian-Barremian was between 50 to $60^{\circ} \mathrm{S}$ (Baumgartner et al. 1992) and although latitudinal temperature gradients were lower in the Lower Cretaceous oceans, significantly cooler temperatures would have occurred at these high latitudes (Frakes and Francis 1988; Frakes et al. 1992). These lower temperatures may explain the absence or rarity of Tethyan species. The paleogeography would also have favored the influx of colder southern water rather than warmer Tethyan water (Baumgartner et al. 1992, Powell et al. 1988). Scheibnerová $(1971 a, 1977,1978)$ proposed the existence during the Early Cretaceous of a cool austral bioprovince at high southern latitudes that was the equivalent of the boreal bioprovince and that comprised Australia, India, South Africa and South America. Its existence is supported by the distinctive composition of assemblages at Site 766, which lack some of the common Tethyan taxa (instead, the various forms of Saracenaria and Lenticulina lineages are particularly well developed). It should be stressed, however, that although cool temperature may have strongly influenced the composition of shallow-water benthic foraminiferal assemblages at high latitudes, deep-water benthic foraminifera are affected by many additional factors, such as nutrient flux, substrate composition, and oxygen levels of the deep-water masses. The cosmopolitan character of the fauna at Site 766 and its relatively high diversity point to the existence of open connections with major world oceans (accentuated by the Valanginian-Barremian first order eustatic sea-level rise, Frakes et al. 1992), which allowed the dispersal of many taxa during the Early Cretaceous. Diachrony in the stratigraphic positions of some taxa suggests migration from the Tethyan to the high latitudes and vice-versa. Moullade and Guérin (1982) demonstrated that the common distribution of benthic foraminifera in numerous DSDP Sites and Tethyan outcrops indicated the presence of open marine connections between the south and central Atlantic Ocean in mid Albian time. Open connections between the austral, Tethyan and boreal realms must have been established since the Valanginian to account for the cosmopolitan nature of the microfauna. 
TABLE 1

Foraminiferal census data from ODP Hole 766A.

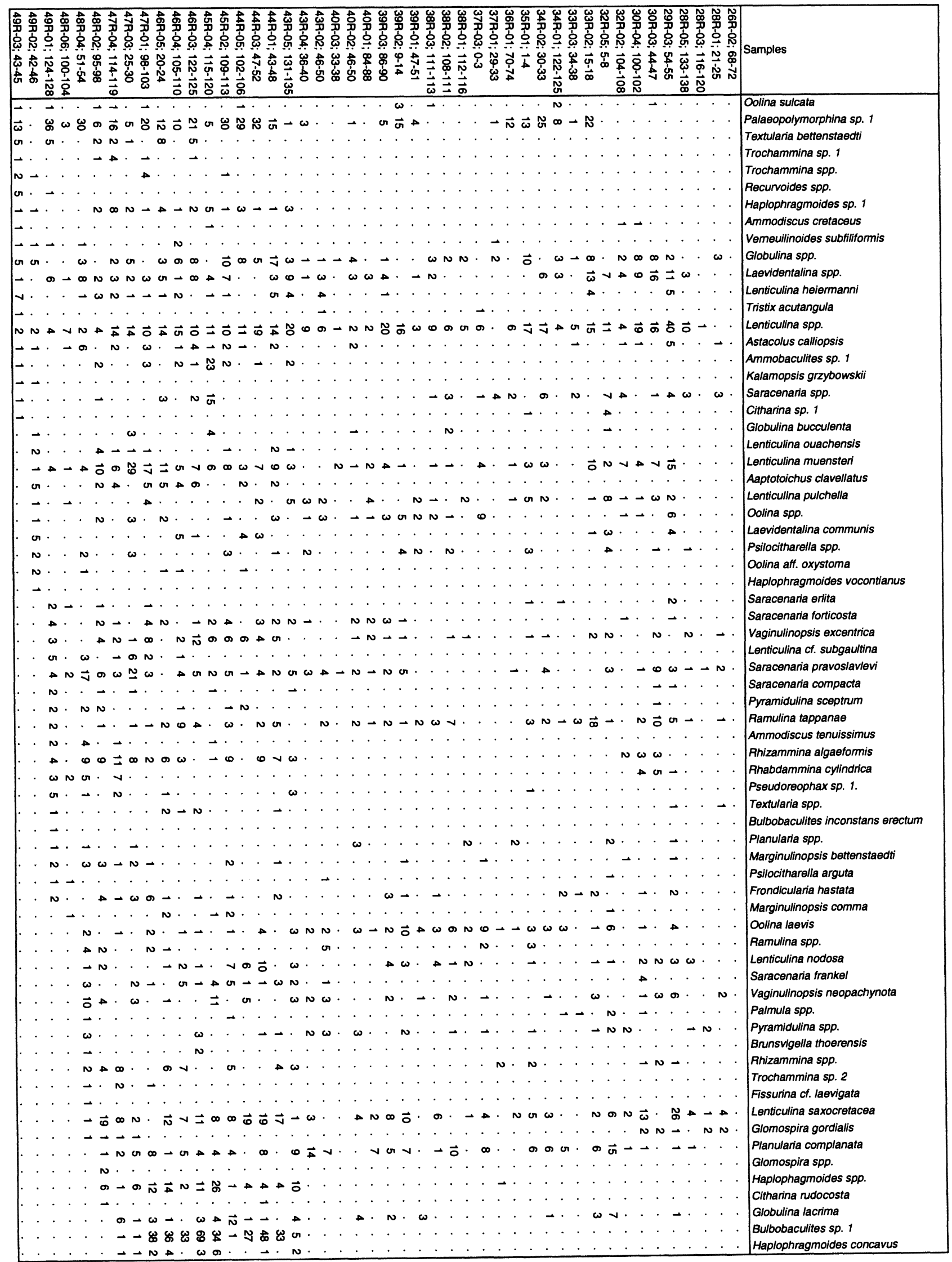


TABLE 1

(continued)

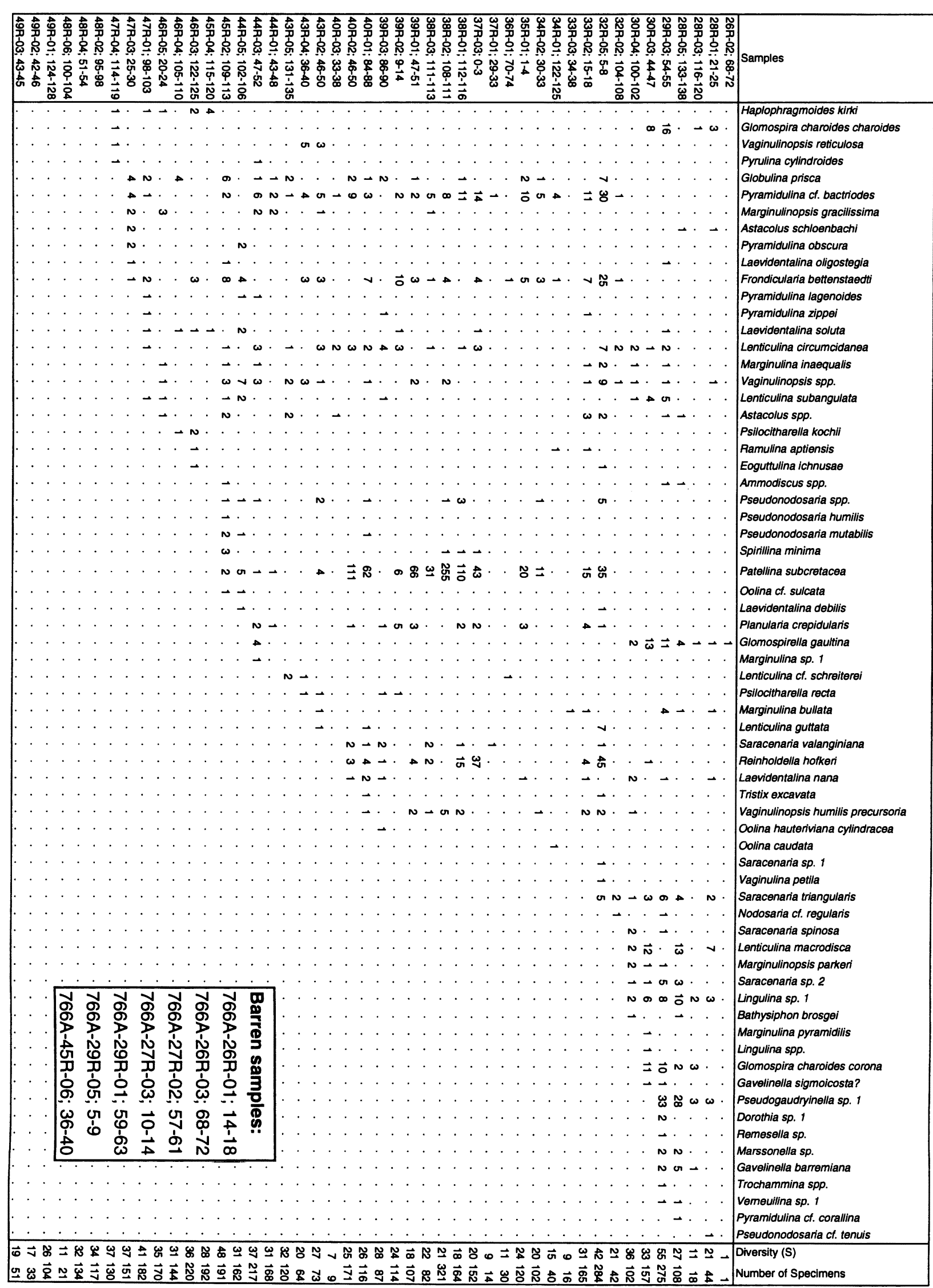




\section{CONCLUSION}

The taxonomic study of Valanginian-Barremian samples from ODP Site 766 provides a unique insight into the composition of bathyal foraminiferal assemblages at high southern latitudes during the Early Cretaceous. One hundred eighteen species of benthic foraminifera have been recorded, 88 of them calcareous and 30 agglutinated. Thirty-two taxa that did not closely match published taxonomic descriptions have been described in open nomenclature.

Benthic foraminifera can be used to subdivide the Valanginian-Barremian interval at ODP Site 766 into four assemblages: 1) An upper Valanginian-lower Hauterivian Lenticulina ouachensis - Textularia bettenstaedti assemblage characterized by Lenticulina ouachensis, Textularia bettenstaedti, Bulbobaculites sp. 1, Ammodiscus tenuissimus, Aaptotoichus clavellatus, Rhizammina spp.and Haplophragmoides spp. 2) A lower Hauterivian Lenticulina heiermanni - Saracenaria forticosta assemblage characterized by Lenticulina heiermanni, Saracenaria forticosta, Globulina spp., Oolina spp. and diverse nodosariids. 3) An upper Hauterivian Planularia crepidularis - Patellina subcretacea assemblage characterized by Planularia crepidularis, Patellina subcretacea, Saracenaria valanginiana and Reinholdella hofkeri. 4) A Barremian Gavelinella barremiana - Pseudogaudryinella sp. 1 assemblage characterized by Gavelinella barremiana, Pseudogaudryinella sp. 1, Saracenaria spinosa, Lenticulina macrodisca, Lingulina sp. 1, Glomospirella gaultina and Glomospira spp. The assemblages are important indicators of environmental and sedimentary changes, linked either to regional events or to eustatic sea-level changes and plate tectonics developments on a global scale.

A comparison of the occurrences of biostratigraphically important taxa from Site 766 with their ranges in the published boreal and Tethyan zonations points to the cosmopolitan distribution of many bathyal taxa in the Lower Cretaceous. The assemblages at Site 766 bear closest resemblance to the bathyal faunas from the northern margin of the Tethys described by Weidich (1990), suggesting deep water connections with the world oceans. However, detailed comparisons of their ranges in the northern and southern hemispheres revealed some important discrepancies: some species that are stratigraphical index taxa in both Tethyan and boreal zonations are missing at Site 766 (in particular, Epistomina and Marssonella lineages), a number of species occur earlier at Site 766 than previously recorded (e.g. L. heiermanni, S. forticosta and S. spinosa) and others have truncated stratigraphical ranges. The distinctive composition and stratigraphic ranges of the fauna support the existence of an austral bioprovince during the Early Cretaceous.

Finally, we point out some problems of foraminiferal systematics, especially among the nodosariids, which show great variability. The taxonomic criteria which are used are often highly subjective, leading to arbitrary classification. Such difficulties are compounded by inaccessibility of type specimens and a lack of coordinated effort to reevaluate earlier classifications. There is an urgent need for taxonomic reappraisal to assure the validity of stratigraphic correlations and paleoenvironmental analyses. Further research at other Indian Ocean DSDP and ODP Sites will lead to a better understanding of cosmopolitan faunal distribution and paleocirculation in the austral realm and help unravel the early evolution of the Indian Ocean during the Early Cretaceous.

\section{SYSTEMATIC TAXONOMY}

The microfauna recovered from Site 766 consists predominantly of calcareous foraminifera with a rich nodosariid component and variable numbers of agglutinated foraminifera, ostracods, radiolarians, fish teeth and echinoderm fragments. Preservation is generally moderate to good, except for several intervals where fragile calcareous tests are partially dissolved.

The foraminiferal classification follows the classification proposed by Loeblich and Tappan (1987). Open nomenclature has been used for taxa that do not closely match published descriptions. The following abbreviations have been used:

cf. for taxa similar to a known species but different in some detail. aff. for taxa showing close affinity to a well-defined taxonomic group.

sp. $1,2 \ldots$ for species that do not match published descriptions.

sp. for taxa not determinable at the specific level.

It should be noted that the suprageneric classification within the Family Nodosariacea is still controversial as their phylogeny remains uncertain. There is also some taxonomic confusion at the specific and generic levels because nodosariids show considerable variability. Many transitional forms transgress boundaries between species making taxonomic criteria difficult to apply and leading to subjective, arbitrary classifications. Another problem is that many studies have been carried out by researchers working in isolation and the taxonomic schemes used often reflect their own brand of "provincialism."

\section{Phylum PROTOZOA \\ Class SARCODINA \\ Order FORAMINIFERIDA Eichwald 1830 \\ Suborder TEXTULARIINA Delage and Hérouard 1896 \\ Superfamily ASTRORHIZACEA Brady 1881 \\ Family BATHYSIPHONIDAE Avnimelech 1952 \\ Genus Bathysiphon Sars 1872}

Bathysiphon brosgei Tappan 1957

Plate 1, figures 1a, 1b

Bathysiphon brosgei TAPPAN 1957, pl. 65, figs. 1-5. - TAPPAN 1962, pl. 29, figs. 1-5. - WEIDICH 1990, pl. 1, fig. 8; pl. 33, figs. 13-14.

Description: Straight, slender, cylindrical test with well cemented, finely agglutinated wall.

Range and Occurrence: A cosmopolitan Cretaceous species found mostly in flysch facies (Weidich 1990).

Family RHABDAMMININAE Brady 1884

Subfamily RHABDAMMININAE Brady 1884

Genus Rhabdammina Sars 1869

Rhabdammina cylindrica Glaessner 1937

Plate 1, figures 3-4

Rhabdammina cylindrica GLAESSNER 1937; pl. 1, fig. 1. - WEIDICH 1990 , pl. 1, fig. 2; pl. 33, figs. 2-3.

Description: Slender, tubular, straight test, very coarsely agglutinated.

Remarks: Specimens in Site 766 are somewhat flattened.

Range and Occurrence: A cosmopolitan Cretaceous to Paleogene species (Weidich 1990).

Genus Rhizammina Brady 1879

Rhizammina algaeformis Brady 1879

Plate 1, figure 5 
TABLE 2

A comparison of stratigraphic ranges of index taxa from (1) Bartenstein and Bettenstaedt 1962; (2) Bartenstein 1979; (3) Hart et al. 1989; (4) Weidich 1990; (5) Riegraf and Luterbacher 1989a.

\section{Species name \\ Astacolus schloenbachi \\ Bulbobaculites inconstans \\ Laevidentalina debilis \\ Frondicularia hastata \\ Gavelinella barremiana \\ Gavelinella sigmoicosta \\ Bar. \\ Globulina prisca \\ Lagena hauteriviana \\ Lenticulina guttata \\ Lenticulina heiermanni \\ Lenticulina muensteri \\ Lenticulina nodosa and subspecies upper Val. - Bar. \\ Range at Site 766 \\ upper Val. - Bar. \\ upper Val. - Haut. \\ Bar. \\ upper Val. - Haut. \\ Haut. \\ upper Val. - lower Haut.}

Lenticulina ouachensis

Lenticulina reticulosa

Lenticulina schreiterei

Marginulinopsis bettenstaedti

Marginulinopsis gracilissima

Patellina subcretacea

Planularia crepidularis

Reinholdella hofkeri

Saracenaria forticosta

Saracenaria frankei

Saracenaria spinosa

Saracenaria valanginiana

Textularia bettenstaedti

Tristix excavata

Psilocitharella arguta

Psilocitharella kochii

Psilocitharella recta

Vaginulinopsis humilis precursoria

Vaginulinopsis neopachynota upper Val. - lower Haut.

Haut.

upper Val. - Bar.

upper Val. - lower Haut. Berr.-lower Apt. (3)

Haut.

upper Val. - lower Haut. Berr. to Apt. (4)

Haut. upper Val. - Bar.
Range in Literature

Val.-lower Apt. (3)

Val. to Haut. (1)

Haut. Berr. to Alb. (5)

upper Val. - Bar.Val.-lower Bar. (3)

Berr. to Bar. (4)

mid Bar. to lower Apt. (max. mid Bar.) (1)

mid Bar.-lower Apt. (2)

lower Apt. (3)

Bar. to Apt. (4)

Haut. to Albian (5)

upper Haut. to lower Bar. (max. u. Haut.) (1)

upper Haut.-Bar. (2)

upper Haut.-lower Bar. (3)

lower Bar. (4)

upper Alb. to Cenom. (4)

Haut. Berr.-lower Bar. (3)

Berr.-lower Bar. (2)

Haut.-lower Bar. (3)

Haut. to Bar. (4)

upper Val. - Bar.Berr.-Bar. (3)

upper Val. to lower Haut. (1)

Berr.-Bar., Apt.? (2)

mid-Val. to mid-Barr. (5)

upper Hauteriv. to lower Apt. (max. u.-m. Bar.) (1)

Val.-lower Apt. (2)

upper Val.-Haut. (3)

Berr. to Apt. (4)

lower Val. to lower Apt. (5)

upper Val. - lower Haut.Val.-lower Apt. (2)

Haut. Val.-Alb. (2)

upper Val.-Haut., lower Apt. (3)

Berr. to Apt. (4)

(max. upper Val.)lower Haut. to mid Bar. (max. Haut.) (1)

mid-Val. to mid-Bar. (5)

mid Val. to lower Apt. (max. u. Haut - m. Bar.) (1)

Haut. Berr. to lower Apt. (4)

upper Val. to mid Bar. (max. u. Haut.) (1)

Tith.-lower Apt. (2)

upper Val.- lower Apt. (3)

Haut. Berr.-Val. (2)

upper Val. - Haut.lower Bar. to lower Apt. (max. mid Bar.) (1)

mid Bar.-lower Apt. (2)

Bar. to Apt. (4)

upper Val. - Haut.upper Val.-lower Apt. (2)

Bar. lower Apt. to lower Alb. (max. u. Apt.) (1)

Apt.-lower Alb. (2)

upper Apt. (4)

Berr.-Val. (2)

Val. (3)

upper Haut. to lower Alb. (max. u. Apt - 1. Alb.) (1)

upper Alb. to Cenom. (4)

upper Val. - Haut. upper Val.-Cenom. (2)

upper Val.-lower Bar. (3)

lower Haut.upper Val.-lower Apt. (2)

Bar. to Apt. (4)

Haut. mid Bar.-lower Cenom. (2)

upper Haut. Val.-lower Apt. (3)

Haut.-Bar. (2) 
Rhizammina algaeformis BRADY 1879, pl. 4, figs. 16-17. - WEIDICH 1990, pl. 33, figs. 7-8.

Description: Slender, tubular test, quite coarsely agglutinated, flattened in cross-section and markedly bent.

Range and Occurrence: Cosmopolitan Cretaceous species, typical of turbid and cold environment in deep basins (Weidich 1990).

Superfamily AMMODISCACEA Reuss 1862

Family AMMODISCIDAE REUSS 1862

Subfamily AMMOVERTELLININAE Saidova 1981

Genus Glomospira Rzehak 1885

Finely agglutinated, tubular test with aperture at open end of tube, streptospirally enrolled at least in its early part. Classified into subgroups by Weidich (1990) according to the regularity of coiling.

Glomospira charoides charoides (Jones and Parker 1860)

Plate 1, figure 13

Trochammina squamata var. charoides JONES and PARKER 1860, p.304. Glomospira charoides charoides (Jones and Parker) - WEIDICH 1990, pl. 34, fig. 7, 11.

Glomospira charoides (Jones and Parker) - BERGGREN and KAMINSKI 1990, pl. 1, fig. 2.

Description: Irregularly coiled about an axis.

Remarks: Berggren and Kaminski (1990) designated a lectotype from the W.K. Parker collection at the B.M.N.H.

Range and Occurrence: Cosmopolitan throughout the Early Cretaceous.

Glomospira charoides corona Cushman and Jarvis 1928

Plate 2, figures 1a, 1b, 3a, 3b.

Glomospira charoides var. corona CUSHMAN and JARVIS 1928, pl. 12, figs. 9-11.

Glomospira corona Cushman and Jarvis. - TAPPAN 1962, pl. 29, fig. 13-16.

Glomospira charoides corona Cushman and Jarvis. — WEIDICH 1990, pl. 34 , fig. 8-9.

Description: Distinctive crown-shaped coiling. May be a growth stage of Glomospira charoides.

Range and Occurrence: Cosmopolitan species appearing in the Barremian.

Glomospira gordialis (Jones and Parker 1860)

Trochammina squamata var. gordialis JONES and PARKER 1860, p. 304. Glomospira gordialis (Jones and Parker). - BARTENSTEIN and BRAND 1951, pl. 1, figs. 15-16. - BERGGREN and KAMINSKI 1990, pl. 1, fig. 1.

Description: Test remains irregularly coiled.

Remarks: Berggren and Kaminski (1990) designated a lectotype from the W.K. Parker collection at the B.M.N.H.

Range and Occurrence: Cosmopolitan throughout the Early Cretaceous.

Genus Glomospirella Plummer 1945

Glomospirella gaultina (Berthelin 1880)

Plate 1, figures 10-12

Ammodiscus gaultinus BERTHELIN 1880, pl. 1, fig. 3.
Glomospirella gaultina (Berthelin). - RIEGRAF and LUTERBACHER 1989a, pl. 1, figs. 16-17.

Description: Tubular test, glomospiral initially, becomes planispiral. Aperture at open end of tube.

Range and Occurrence: Cosmopolitan in the Early Cretaceous.

Subfamily AMMOVOLUMMINAE Chernykh 1967

Genus Ammodiscus Reuss 1862

Ammodiscus cretaceus (Reuss 1845)

Plate 1, figures 7-8

Operculina cretacea REUSS 1845, pl. 13, figs. 64-65.

Ammodiscus cretaceus (Reuss). - TAPPAN 1962, pl. 30, figs. 1-2. WEIDICH 1990, pl. 1, fig. 15.

Description: Finely agglutinated, tubular test with globular proloculus and planispirally coiled second chamber increasing gradually in diameter. The whorls of the coil are slightly overlapping and the test may be occasionally constricted. Aperture at end of open tube.

Range and Occurrence: Cosmopolitan throughout the Cretaceous.

Ammodiscus tenuissimus (Gümbel 1862)

Plate 1, figure 6a, 6b

Spirillina tenuissimus GÜMBEL 1862, pl. 4, fig. 12a, b.

Ammodiscus tenuissimus (Gümbel). - BARTENSTEIN and BRAND

1951, pl. 1, fig. 14. - NEAGU 1975, pl. 1, figs. 1-4, 7-13, 25; pl. 2, figs.

1-14, 16, 21, 30. - KAMINSKI et al. 1992, pl. 2, fig. 3.

Description: Subcircular, tubular test with small, globular proloculus and thin, planispiral second chamber increasing in size very gradually. Test composed of fine agglutinated particles cemented in a fine siliceous matrix, giving the test a slightly rough appearance. Aperture at end of open tube.

Range and Occurrence: Late Valanginian in northwestern Germany (Bartenstein and Brand 1951), Hauterivian in Rumania (Neagu 1975) and earliest Cretaceous at ODP Site 765 (Kaminski et al. 1992).

Superfamily HORMOSINACEA Haeckel 1894 Family ASCHEMOCELLIDAE Vyalov 1966 Genus Kalamopsis de Folin 1883

Kalamopsis grzybowskii (Dylazanka 1923)

Hyperammina grzybowskii DYLAZANKA 1923, p. 65-66.

Kalamopsis grzybowski (Dylazanka). - KAMINSKI and GEROCH 1993, pl. 17, figs. 5a-8.

Description: A narrow tube with constrictions.

Range and occurrence: A single specimen. Reported from the Lower Cretaceous of Site 765 (Kaminski et al. 1992).

Superfamily LITUOLACEA de Blainville 1827

Family HAPLOPHRAGMOIDIDAE Maync 1952

Genus Haplophragmoides Cushman 1910

Haplophragmoides concavus (Chapman 1892)

Plate 2, figures 5, 7

Trochammina concava CHAPMAN 1892, pl. 6, fig. 14a, b.

Haplophragmoides concavus (Chapman). - NEAGU 1975, pl. 12, figs.

3-15. - WEIDICH 1990, pl. 7, figs. 2, 11, 19; pl. 36, figs. 5-6. 
Description: Biumbilicate, planispiral test, slightly evolute, usually with five or six chambers in last whorl. Straight, depressed sutures, deep umbilicus and finely agglutinated wall. The apertural slit at the base of the last chamber is rarely visible.

Remarks: Specimens at Site 766 show appreciable variability in size, number of chambers and degree of diagenetic compression.

Range and Occurrence: Cosmopolitan species in the Early Cretaceous (Weidich 1990).

Haplophragmoides cf. vocontianus Moullade 1966 Plate 2, figure 4

Haplophragmoides vocontianus MOULLADE 1966, pl. 1, figs. 1-2.

Description: Biumbilicate, involute, planispiral test, very compressed with eight quadrate chambers in last whorl. Apertural slit at base of last chamber, wall finely agglutinated.

Remarks: The number of chambers in the last whorl does not usually reach 9-11 as described by Moullade (1966).

Haplophragmoides kirki Wickenden 1932

Plate 2, figure 2

Haplophragmoides kirki WICKENDEN 1932, pl. 1, fig. 1. - KAMINSKI et al. 1992, pl. 4, figs. 1a-2.

Description: Planispiral, involute test with four or five moderately inflated chambers in last whorl.

Remarks: Rare in Site 766; aperture not visible.

Range and Occurrence: Originally described from Upper Cretaceous of Alberta. Also reported from the Upper Jurassic-Lower Cretaceous at Site 765 (Kaminski et al. 1992).

Haplophragmoides sp. 1

Plate 2, figure 6

Description: Biumbilicate, planispiral test, markedly evolute with six chambers in the last whorl. Periphery lobulate, chambers somewhat flattened with straight, depressed sutures. Aperture an elongate slit at the base of the apertural face, wall finely agglutinated.

Remarks: Many tests are distorted by diagenetic compaction.

\section{Haplophragmoides sp.}

Description: Biumbilicate, planispiral, involute test with six inflated chambers in last whorl. Periphery rounded, deep, narrow umbilicus and depressed, straight sutures. Aperture not visible.

Family LITUOLIDAE de Blainville 1827

Subfamily AMMOMARGINULININAE Podobina 1978

Genus Ammobaculites Cushman 1910

\section{Ammobaculites sp. 1}

Plate 2, figure $8 \mathrm{a}, 8 \mathrm{~b}$

Description: Large, robust, very coarsely agglutinated test with large planispiral coil and indistinct sutures.

Remarks: Specimens in Site 766 are mostly closely enrolled without a distinct uncoiled portion. They appear at marked horizons in the sedimentary sequence, probably reflecting the cyclic influx of coarse clasts.
Family AMMOBACULINIDAE Saidova 1981

Genus Bulbobaculites Maync 1952

Bulbobaculites sp. 1

Plate 2, figure 9

Description: Elongated test with small, streptospiral, early stage and very coarsely agglutinated wall. Sutures and number of chambers indistinct due to very large agglutinated particles.

Remarks: Found mostly in association with Ammobaculites sp.1, also a very coarsely agglutinated species. The occurrence of these two species at specific levels reflects sedimentary pulses of coarser particles.

Bulbobaculites inconstans erectum (Bartenstein and Brand 1951) Plate 2, figure 10

Haplophragmium inconstans erectum BARTENSTEIN and BRAND 1951, pl. 3, figs. 50-55. — MICHAEL 1974, pl. 1, fig. 7.

Description: Elongated test, cylindrical in cross-section with small streptospiral early stage becoming uniserial. Chambers broader than high and separated by deep sutures, last chamber markedly pointed towards terminal aperture. Wall firmly cemented, with some coarse particles.

Range and Occurrence: Originally described from Valanginian of northwestern Germany by Bartenstein and Brand (1951).

Superfamily HAPLOPHRAGMIACEA Eimer and Fickert 1899

Family AMMOSPHAEROIDININAE Cushman 1927

Subfamily RECURVOIDINAE Alekseychik-Mitskevich 1973

Genus Recurvoides Earland 1934

Recurvoides sp.

Description: Small, trochospirally enrolled test.

Remarks: Rare in Site 766. Specimens are often compressed and apertures rarely visible.

Superfamily SPIROPLECTAMMINACEA Cushman 1927 Family TEXTULARIOPSIDAE Loeblich and Tappan 1982 Genus Aaptotoichus Loeblich and Tappan 1982

Aaptotoichus clavellatus (Bartenstein and Brand 1951)

Plate 3, figure 2a, 2b

Bigenerina clavellata BARTENSTEIN and BRAND 1951, pl. 4, figs. 75-76.

Aaptotoichus clavellatus (Bartenstein and Brand). - LOEBLICH and TAPPAN 1988, pl. 122, figs. 1-4.

Description: Small, finely agglutinated, compressed test, biserial at first, becoming uniserial and flaring, Last chamber flattened and rounded, small, terminal aperture rarely visible.

Range and Occurrence: Found in upper Valanginian deposits of northwestern Germany (Bartenstein and Brand 1951), upper Valanginian-lower Hauterivian of Rumania (Neagu 1975), Barremian alpine sediments (Weidich 1990) and Lower Cretaceous of Trinidad and Texas (Loeblich and Tappan 1988). 
Superfamily TROCHAMMINACEA Schwager 1877

Family TROCHAMMINADAE Schwager 1877

Subfamily TROCHAMMININAE Schwager 1877

Genus Trochammina Parker and Jones 1859

Trochammina sp. 1

Plate 3, fig. 3a, 3b.

Description: Trochospiral, planoconvex, flattened test with five chambers in last whorl and lobate periphery.

Remarks: Few, poorly preserved specimens recovered.

Trochammina sp. 2

Plate 3, figure $4 a, 4 b$

Description: Trochospiral, spiroconvex test with two and a half whorls of five chambers and lobate periphery. Chambers inflated, increasing quite rapidly in size; sutures radial and umbilicus markedly depressed.

Remarks: Rare at Site 766.

Superfamily VERNEUILINACEA Cushman 1911

Family VERNEUILINIDAE Cushman 1911

Subfamily VERNEUILINOIDINAE Suleymanov 1973

Genus Pseudoreophax Geroch 1961

Pseudoreophax sp. 1

Plate 3, figure 5a, 5b

Description: Slender, elongated, finely agglutinated test with circular cross-section. Trochospiral in early stage becoming uniserial along a twisted axis; aperture terminal, usually indistinct.

Remarks: Only few specimens present. Differs from Pseudoreophax cisovnicensis Geroch in possessing more numerous chambers and a more tapered initial part.

Genus Verneuilinoides Loeblich and Tappan 1949

Verneuilinoides subfiliformis Bartenstein 1952

Plate 3, figure $6 a, 6 b$

Verneuilinoides subfiliformis BARTENSTEIN 1952, pl. 12a, figs. 1-11. BARTENSTEIN and BOLLI 1986, pl. 2, figs. 23-25. - WEIDICH 1990; pl. 32, fig. 9.

Description: Elongated, triserial test, subrounded in cross-section with numerous chambers (usually ten or more), separated by distinct sutures. Wall finely agglutinated, interiomarginal arched aperture.

Remarks: Bartenstein and Bolli (1986) suggested that this species evolved from $V$. neocomiensis Mjatliuk and is a precursor to Dorothia filiformis Berthelin.

Range and Occurrence: A cosmopolitan species from the Hauterivian to early Albian.

Subfamily VERNEUILININAE Cushman 1911

Genus Pseudogaudryinella Cushman 1911

Pseudogaudryinella sp. 1

Plate 3, figure 10

Description: Elongate test, initially triserial, then becoming biserial to uniserial. Aperture interiomarginal in biserial stage or terminal in uniserial stage.
Remarks: Specimens from Site 766 usually lack a uniserial stage. Common in Cores 766A-30R-28R.

Genus Verneuilina d'Orbigny 1839

Verneuilina sp. 1

Plate 3, figure 8

Description: Elongate, triangular test with chambers triserially arranged and interiomarginal apertural arch.

Remarks: Present in Cores 766A-30R-28R.

Superfamily ATAXOPHRAGMIACEA Schwager 1877

Family GLOBOTEXTULARIIDAE Cushman 1927

Subfamily LIEBUSELLINAE Saidova 1981

Genus Remesella Vasicek 1947

Remesella sp.

Plate 3, figure 7

Description: Elongate, subconical test with chambers trochospirally enrolled initially, then becoming biserial. Well-cemented wall and interiomarginal apertural arch.

Remarks: Present in Cores 766A-30R-28R.

Superfamily TEXTULARIACEA Ehrenberg 1838

Family EGGERELLIDAE Cushman 1932

Subfamily DOROTHINAE Balakhmatova 1972

Genus Dorothia Plummer 1931

Dorothia sp. 1

Plate 3, figure 11

Description: Elongated, finely agglutinated test, subcircular in cross-section, with moderately inflated chambers and nearly parallel sides. Trochospiral in early stage, later biserial, with an interiomarginal apertural slit on the last chamber.

Remarks: Common in Cores 766A-30R-28R.

Genus Marssonella Cushman 1933

Marssonella sp.

Description: Conical, subcylindrical test with trochospiral early stage, becoming triserial, then biserial. Wall finely agglutinated, aperture interiomarginal.

Remarks: Few, poorly preserved specimens.

Family TEXTULARIDAE Ehrenberg 1838

Subfamily TEXTULARIINAE Ehrenberg 1838

Genus Textularia Defrance 1824

Textularia bettenstaedti Bartenstein and Oertli 1977

Plate 3, figure 9

Textularia bettenstaedti BARTENSTEIN and OERTLI 1977, figs. 3, 4. BARTENSTEIN and KOVATCHEVA 1982, pl. 1, figs. 24-25.

Description: Long, narrow, biserial test with 12 alternating chambers separated by depressed sutures. Agglutinated wall with characteristic "coal dust" grains, especially along the sutures; apertural slit on the inner side of the last chamber,

Range and Occurrence: Cosmopolitan species in temperate and Tethyan facies (Bartenstein and Kovatcheva 1982). Rare in the 
Valanginian-middle Barremian and early Aptian, common in the late Aptian-early Barremian (Bartenstein and Oertli 1977). Reported from the upper Hauterivian to lower Albian in the boreal fauna of the Central North Sea (King et al. 1989). Characterizes the basal assemblage (late Valanginian) at Site 766.

Suborder SPIRILLININA Hoenegger and Piller 1975

Family PATELLINIDAE Rhumbler 1906

Subfamily PATELLININAE Rhumbler 1906

Genus Patellina Williamson 1858

Patellina subcretacea Cushman and Alexander 1930

Plate 14, figures $7 \mathrm{a}, 7 \mathrm{~b}$ and $8 \mathrm{a}, 8 \mathrm{~b}$.

Patellina subcretacea CUSHMAN and ALEXANDER 1930, pl. 3, fig. 1a, b. - BARTENSTEIN and BRAND 1951, pl. 11, fig. 319. - NEAGU 1975, pl. 82, figs. 1-16; pl. 85, figs. 26-29.

Description: Conical test, evolute on spiral side and involute on ventral side. Two chambers per whorl, narrower at the ends and separated by weakly carinate spiral sutures. Scroll-like median septum, radiating grooves and nodes distinct on ventral side of well preserved specimens. Pores are present on outer wall of chambers.

Range and Occurrence: Recorded from the middle and upper Valanginian in northwestern Germany (Bartenstein and Brand 1951), from the Hauterivian, Barremian and lower Aptian in Rumania (Neagu 1975) and in Berriasian-lower Aptian sediments of the Bavarian Alps (Weidich 1990).

Family SPIRILLINIDAE Reuss and Fritsch 1861

Genus Spirillina Ehrenberg 1843

Spirillina minima Schacko 1892

Plate 14, figure 9a, 9b

Spirillina minima SCHACKO 1892; pl. 1, fig. 4. - BARTENSTEIN and KOVATCHEVA 1982, pl. 4, figs. 38, 39; pl. 5, figs. 43-44. - WEIDICH 1990, pl. 44, fig. 28.

Description: Discoidal test with small proloculus and gradually increasing tubular second chamber, initially trochospiral, becoming planispiral. Aperture at end of open tube. Numerous pores on test surface.

Range and Occurrence: Widely recorded in the Lower Cretaceous.

Suborder LAGENINA Delage and Hérouard 1896

Superfamily NODOSARIACEA Ehrenberg 1836

Family NODOSARIIDAE Ehrenberg 1838

Subfamily NODOSARIINAE Ehrenberg 1838

Genus Laevidentalina Loeblich and Tappan 1986

Laevidentalina communis (d'Orbigny 1826)

Plate 4, figures 1a-3c

Nodosaria communis d'ORBIGNY 1826 p. 254.

Dentalina communis (d'Orbigny). - BARTENSTEIN and BRAND 1951 , pl. 9, figs. 228-231. - BARTENSTEIN and BOLLI 1986; pl. 2, figs. 36-37.

Description: Elongated, uniserial test with a slightly curved axis. Variable number of chambers, increasing slowly in size and separated by inclined, slightly depressed sutures.

Range and Occurrence: A cosmopolitan species commonly recorded in the Lower Cretaceous.
Laevidentalina debilis (Berthelin 1880)

Marginulina debilis BERTHELIN 1880, pl. 3, fig. 28.

Dentalina debilis (Berthelin). - BARTENSTEIN and BRAND 1951, pl. 10, fig. 239-240a.

Lenticulina (Vaginulina) debilis (Berthelin). - MOULLADE 1984, pl. 3, fig. 13.

Description: Elongated, uniserial, thin test with sharp dorsal edge and rounded ventral side. Chambers inflated ventrally and separated by strongly depressed, inclined sutures.

Remarks: Only found as fragments.

Range and Occurrence: Cosmopolitan in the Lower Cretaceous (Bartenstein and Brand 1951).

Laevidentalina nana (Reuss 1863)

Plate 4, figure $4 a, 4 b$

Dentalina nana REUSS 1863, pl. 2, figs. 10, 18. - FUCHS and STRADNER 1967, pl. 7, fig. 5. - MOULLADE 1984, pl. 2, fig. 15. - MEYN and VESPERMANN 1994, pl. 7, figs. 8-16; pl. 8, figs. 1-3.

Description: Uniserial, elongated, straight to slightly curved test, subcylindrical in cross-section with very wide chambers (five or more), becoming slightly elongated and inflated. The last chamber tapers towards a terminal, dorsal aperture while the first chamber is markedly rounded. Sutures are oblique and slightly depressed.

Range and Occurrence: Albian in the Netherlands (Fuchs and Stradner 1967) and in Atlantic and Tethys (Moullade 1984). Barremian-Cenomanian in the northern Alps (Weidich 1990).

Laevidentalina oligostegia (Reuss 1845)

Plate 4, figure 5a, 5b

Nodosaria oligostegia REUSS 1845, pl. 13, figs. 19-20.

Dentalina oligostegia (Reuss) MOULLADE 1984, pl. 2, fig. 16. WEIDICH 1990, pl. 25, fig. 10; pl. 40, fig. 8.

Description: Uniserial, elongated test consisting of two ovate chambers, separated by distinctly depressed sutures. Last chamber elongated towards terminal radiate aperture on dorsal side.

Range and Occurrence: Albian in the Atlantic and Tethys (Moullade 1984). Aptian-Albian in the northern Alps (Weidich 1990).

Laevidentalina soluta (Reuss 1851)

Plate 4, figure 6a, 6b

Dentalina soluta REUSS 1851, pl. 3, fig. 4a, b.

Dentalina soluta (Reuss). - BARTENSTEIN and BRAND 1951, pl. 9, fig. 237. - WEIDICH 1990, pl. 39, figs. 11-12; pl. 40, fig. 7.

Description: Uniserial, elongated test with spherical chambers strongly strangulated by very depressed, wide sutures.

Remarks: Mostly found as fragments, broken off at sutures.

Range and Occurrence: Mid to late Valanginian in northwestern Germany (Bartenstein and Brand 1951). Hauterivian-Cenomanian in the northern Alps (Weidich 1990).

Genus Nodosaria Lamarck 1812

Nodosaria cf. regularis Terquem 1862

Plate 4, figure 12

Nodosaria regularis TERQUEM 1862, pl. 5, fig. 12.

Nodosaria cf. regularis Terquem. - BARTENSTEIN and BRAND 1951, pl. 10, figs. 244-245. 
Description: Uniserial, rectilinear test, usually consisting of only two chambers strongly strangulated by a deep suture. The first chamber is more spherical and distinctly pointed at the base, the second is elongated towards a terminal central aperture.

Range and Occurrence: Late Valanginian-early Hauterivian in northwestern Germany (Bartenstein and Brand 1951).

Genus Pyramidulina Fornasini 1894

Pyramidulina cf. bactriodes (Reuss 1863)

Plate 4, figures 8-9

Nodosaria bactriodes REUSS 1863, pl. 2, fig. 5. - NEAGU 1975, pl. 71, figs. 11-14.

Description: Short, costate test with large, inflated first chamber followed by two or three smaller chambers, gradually decreasing in size and tapering towards central apertural neck. Basal disc may originally have surrounded a spine. Sutures slightly depressed, a variable number of prominent costae ornament the test.

Remarks: Closest to specimen illustrated by Neagu (1975) in pl. 71, fig. 11. Differs from $P$. bactriodes Reuss in the smaller number of chambers, shorter test and variable number of costae. Also close to the Jurassic species $P$. dispar Franke, illustrated by Exton (1979) in pl. 2, fig. 1. This Jurassic species is very variable leading to taxonomic confusion. Bach et al. (1959) established the synonymy between $P$. dispar Franke, $P$. hortensis Terquem, $P$. variabilis Terquem and Berthelin, $P$. fontinensis Terquem and $P$. mutabilis Terquem, renamed $P$. reiseckei Hagenmeyer. Exton (1979), however, retained them as distinct species. The specimens from Site 766 most closely resemble $P$. dispar Franke, described by Exton (1979), although they are slightly more inflated. The two and three chambered specimens of $P$. reineckei described by Hagenmeyer in Bach et al. (1959) are considered to be juvenile stages. The predominance of short tests in Site 766 suggests, however, that they are adult individuals.

Range and Occurrence: Early Hauterivian in Rumania (Neagu 1975).

\section{Pyramidulina cf. corallina (Gümbel 1862)}

Plate 4, figure 10

Nodosaria corallina GÜMBEL 1862, pl. 3, fig. 10a, b. - RIEGRAF and LUTERBACHER 1989b, pl. 3, figs. 4-5. - WEIDICH 1990, pl. 24, fig. 6.

Description: Uniserial, elongated test with near spherical chambers increasing slowly in size. The chambers are ornamented by longitudinal ribs and separated by deep, straight sutures.

Remarks: The number of ribs (12 in younger chambers) is higher than on the specimen illustrated by Gümbel. Very rare, may not be in situ.

Range and Occurrence: Callovian-Kimmeridgian in the North Atlantic, Germany and in the eastern Indian Ocean (Riegraf and Luterbacher 1989b).

Pyramidulina lagenoides (Wisniowski 1890)

Plate 4, figure 11

Nodosaria lagenoides WISNIOWSKI 1890, pl. 8, fig. 25. — KUZNETSOVA 1974, pl. 2, fig. 22.

Description: Ovate test with prominently inflated, costate first chamber and very reduced second and third chambers, barely visible below apertural neck.
Range and Occurrence: Late Jurassic species, very rare in Site 766, perhaps reworked.

Pyramidulina obscura (Reuss 1845)

Plate 4, figure 13a, 13b

Nodosaria obscura REUSS 1845, pl. 13, figs. 7-9. - BARTENSTEIN and BRAND 1951, pl. 10, figs. 247-248. - WEIDICH 1990, pl. 25, fig. 1; pl. 39, figs. 7-8.

Description: Small, uniserial, cylindrical test with five or six sub-spherical chambers, the first one being slightly pointed. The chambers are ornamented by 12 fine longitudinal ribs and separated by faintly depressed sutures.

Range and Occurrence: Widely recorded in Lower and Upper Cretaceous sediments (Bartenstein and Brand 1951).

Pyramidulina sceptrum (Reuss 1863)

Nodosaria sceptrum REUSS 1863, pl. 2, fig. 3. - NEAGU 1975, pl. 70, figs. 3-5, 7. - HAIG 1982, pl. 2, figs. 29-32.

Description: Elongate test with chambers broader at base and straight, depressed sutures. Test increases slowly in size and is ornamented by fine, longitudinal costae. Simple, terminal aperture.

Remarks: Occurs mostly as fragments.

Range and Occurrence: Barremian in Rumania (Neagu 1975). Aptian-Albian in Queensland (Haig 1982).

Pyramidulina zippei (Reuss 1845)

Plate 4, figure $14 \mathrm{a}, 14 \mathrm{~b}, 14 \mathrm{c}$

Nodosaria zippei REUSS 1845, pl. 8, figs 1-3. - MICHAEL 1974, pl. 2, fig. 12. - KUZNETSOVA 1974, pl. 2, fig. 13. - WEIDICH 1990, pl. 39, fig. 6.

Nodosaria cf. zippei (Reuss). - BARTENSTEIN and BRAND 1951, pl. 10, fig. 249.

Description: Uniserial, rectilinear test with five chambers becoming slightly wider towards the top. The first chamber is spherical and slightly pointed, the last one is flattened with a small apertural neck. Nine prominent, longitudinal costae ornament the test.

Remarks: This species differs somewhat from the original description of Reuss in the number and shape of chambers. It is very similar to Lower Cretaceous specimens illustrated by Bartenstein and Brand (1951), Michael (1974), Kuznetsova (1974) and Weidich (1990).

Range and Occurrence: Late Valanginian-early Hauterivian in northwestern Germany (Bartenstein and Brand 1951), Late Jurassic-Early Cretaceous in the eastern Indian Ocean (Kuznetsova 1974) and Barremian to Aptian in the northern Alps (Weidich 1990). According to Weidich (1990) this is a typical Upper Cretaceous taxon that first appeared in the Early Cretaceous.

\section{Pyramidulina sp.}

Plate 5, figures 1-2

Description: Subglobular test with a compressed basal disc (early chamber?), followed by a single, very large chamber. Aperture terminal at the end of a thin short neck. Prominently raised, longitudinal costae, may be broken into knots.

Remarks: Test may be flattened diagenetically (see pl. 5, figs. 1-2) and costae vary in width and regularity. 
Genus Pseudonodosaria Boomgaart 1949

Pseudonodosaria humilis (Roemer 1841)

Plate 5, figure 3a, 3b

Nodosaria humilis ROEMER 1841, pl. 15, fig. 6.

Pseudoglandulina humilis (Roemer). - BARTENSTEIN and BRAND 1951, pl. 10, figs. 266-271. - NEAGU 1975, pl. 74, figs. 12-13, 15-16, 18-32; pl. 75, figs. 1-4.

Description: Rectilinear test with chambers increasing gradually in size. Straight, flush sutures become depressed in the younger part of test.

Range and Occurrence: Cosmopolitan in the Early Cretaceous (Neagu 1975).

Pseudonodosaria mutabilis (Reuss 1863)

Plate 5, figure 4a, 4b

Glandulina mutabilis REUSS 1863, pl. 5, figs. 7-11.

Pseudonodosaria mutabilis (Reuss). - NEAGU 1975, pl. 73, figs. 32-45; pl. 74, figs. 1-11, 14-15.

Description: Very variable, rectilinear test with inflated chambers of unequal size. Straight sutures flush in the early portion, becoming depressed. Terminal, radiate aperture.

Range and Occurrence: Cosmopolitan in the Early Cretaceous (Neagu 1975).

Pseudonodosaria cf. tenuis (Bornemann 1854)

Glandulina tenuis BORNEMANN 1854, pl. 2, fig. 3a, b.

Pseudoglandulina tenuis (Bornemann). - BARTENSTEIN and BRAND 1951, pl. 13, fig. 249. - NEAGU 1975, pl. 110, figs. 1-5.

Pseudonodosaria cf. tenuis (Bornemann). - WEIDICH 1990, pl. 26, fig. 23.

Description: Elongated, rectilinear test with inflated chambers increasing progressively in size. Flush sutures in early part of test become depressed.

Remarks: Only one well preserved specimen, closest to the form illustrated by Bartenstein and Brand (1951). Species recorded from upper Hauterivian deposits in Rumania (Neagu 1975), from upper Valanginian deposits in northwestern Germany (Bartenstein and Brand 1951), from Albian alpine sediments and from upper Jurassic and Lower Cretaceous deposits in Europe (Weidich 1990).

Subfamily LINGULININAE Loeblich and Tappan 1961

Genus Lingulina d' Orbigny 1826

Lingulina sp. 1

Plate 5, figures $7-8 b$

Lingulina sp. 3, BARTENSTEIN and BRAND 1951, pl. 8, fig. 193. Lingulina sp. SLITER 1980, pl. 13, fig. 16.

Description: Uniserial, slightly compressed elongated test with small initial chambers increasing very rapidly in size and becoming very broad. The last chamber is quite inflated and has a terminal apertural slit.

Remarks: Very similar to the form illustrated by Bartenstein and Brand (1951) but with a more extended apertural slit and a more inflated last chamber. This species has only been rarely recorded in Valanginian deposits by Bartenstein and Brand (1951).

Subfamily FRONDICULARIINAE Reuss 1860

Genus Frondicularia Defrance 1826
Frondicularia hastata Roemer 1842

Plate 5, figures $10 \mathrm{a}-12 \mathrm{~b}$

Frondicularia hastata ROEMER 1842, pl. 7B, fig. 5. - BARTENSTEIN and BRAND 1951, pl. 8, figs. 207-208. - WEIDICH 1990, pl. 25, fig. 21.

Description: Large, narrow, flattened, finely tapered test with very elongated, equitant chambers. Proloculus inflated and rounded with a median carina. Sutures weakly curved and depressed, last chamber strongly tapered towards a terminal, central aperture.

Remarks: Large specimens, often found in fragments.

Range and Occurrence: In northwestern Germany from midValanginian to late Hauterivian (Bartenstein and Brand 1951), in the northern Alps from Berriasian to Barremian (Weidich 1990).

Frondicularia bettenstaedti Zedler 1961

Plate 5, fig. 13; plate 6, figure $1 \mathrm{a}, 1 \mathrm{~b}$

Frondicularia bettenstaedti ZEDLER 1961, pl. 8, figs. 21-22.

Description: Very compressed, lanceolate test with 6-10 low chambers, gradually increasing in width but not changing markedly in height. Small rounded proloculus, distinctly arched, depressed sutures and terminal, slit-like aperture.

Remarks: Very close to $F$. simplicissima Ten Dam 1946. Compared to the specimens of Bartenstein and Kaever (1973), F. bettenstaedti Zedler differs by its more regular outline, smaller proloculus, less angled sutures and more numerous chambers. Zedler (1961) argued that $F$. bettenstaedti is not simply the microspheric generation of $F$ simplicissima Ten Dam and separated the two species on account of their different distribution and stratigraphic ranges. This species also closely resembles Lingulina lamellata Tappan 1940, illustrated by Haig (1982, pl. 3, figs. 25-29).

Range and Occurrence: Used by Zedler (1961) as an index species for the upper Hauterivian in northwestern Germany.

Genus Tristix Macfayden 1941.

Tristix acutangula (Reuss 1863)

Plate 6, figure $2 a, 2 b$

Rhabdogonium acutangulatum REUSS 1863, pl. 4, fig. 14a, b.

Tristix acutangulum (Reuss). - NEAGU 1975, pl. 75, figs. 40-49; pl. 76, figs. 7-11, 13-16.

Tristix acutangula (Reuss). - WEIDICH 1990, pl. 44, figs. 11-12.

Description: Elongated, uniserial, rectilinear test, triangular in cross-section with slightly concave lateral faces. Chambers low, separated by very arched, depressed sutures. Last chamber elongated towards terminal circular aperture.

Remarks: Rare at Site 766, the specimens recovered differ from the Aptian form illustrated by Weidich (1990) in having a more elongated last chamber. The specimens from Site 766 only have five or six chambers, unlike the very elongated variations illustrated by Neagu (1975).

Range and Occurrence: Cosmopolitan throughout the Early Cretaceous (Bartenstein and Bolli 1986).

Tristix excavata (Reuss 1863)

Plate 6, figure 3a, 3b

Rhabdogonium excavatum REUSS 1863, pl. 12, fig. 8a-c.

Tribrachia australiana (Reuss). - SCHEIBNEROVÁ 1974b, pl. 2, fig. 16; pl. 10, fig. 6. - SCHEIBNEROVÁ 1976, pl. 37, fig. 1. 
Tristix excavata (Reuss). - HAIG 1982, pl. 7, figs. 16-17.

Description: Elongated, uniserial, tapering test, triangular in crosssection with distinctly concave lateral faces. Eight low chambers are separated by strongly arched, depressed sutures which are steeply inclined downwards. Last chamber rounded with simple aperture.

Remarks: The specimens from Site 766 closely resemble $T$. excavata Reuss, illustrated by Haig (1982) and Tribrachia australiana Ludbrook illustrated by Scheibnerová (1976). The specimens are also very similar to Tricarinella excavata originally described by Reuss (1863) and illustrated by Sliter (1980), Moullade (1984) and Weidich (1990) but are generally narrower, more tapered and lack a drawn-out aperture.

Riegraf and Luterbacher (1989b) did not taxonomically differentiate Tristix tunassica Shokhina 1960 and its synonym Tristix lanceola Sliter 1980 from the very variable species T. excavata Reuss 1863. Tristix excavata Reuss 1863 , however, clearly possesses a triangular cross-section with three nearly equal sides, while both T. tunassica Shokhina 1960 and T. lanceola Sliter 1980 are unevenly quadrate (test wider than thick) as illustrated by Weidich (1990). The photograph of T. tunassica Shokhina 1960 in Riegraf and Luterbacher (1989b) is, unfortunately, too vague to clarify the matter.

Range and Occurrence: Tristix excavata Reuss has been recorded in the Valanginian-Barremian of the southwestern Atlantic (Sliter 1977), from the mid Albian in the northern Alps (Weidich 1990), in the late Albian-Cenomanian of Papua New Guinea (Haig 1981) and in the late Albian of Queensland (Haig 1982). Scheibnerová also found Tribrachia australiana Ludbrook in Aptian-Albian sediments at ODP sites in the eastern Indian Ocean (1974b) and in Albian sediments of the Great Australian Basin (1976).

Family VAGINULINIDAE Ehrenberg 1838

Subfamily LENTICULININAE Chapman, Parr and Collins 1934 Genus Lenticulina Lamarck 1804

\section{Lenticulina circumcidanea (Berthelin 1880)}

Plate 6, figure 4

Cristellaria circumcidanea BERTHELIN 1880, pl. 3, fig. 1.

Lenticulina circumcidanea (Berthelin). - JENDRYKA-FUGLEWICZ 1975, pl. 13, figs. 5-7.

Description: Involute test, subcircular in outline with 7-8 chambers in the last whorl. Periphery acute with a narrow keel, sutures curved, flush in the early part becoming faintly depressed. Aperture radiate at peripheral angle and small, depressed umbilicus.

Remarks: Keel development varies in specimens from Site 766.

Range and Occurrence: Found in the Valanginian-Hauterivian of Poland and in the Albian of France (Jendryka-Fuglewicz 1975), also in the Albian of the northern Alps (Weidich 1990).

\section{Lenticulina guttata (Ten Dam 1946)}

Plate 13, figures $7-8 \mathrm{c}$

Lenticulina guttata TEN DAM 1946, pl. 88, fig. 2. - NEAGU 1975, pl. 50 , figs. 1-2; pl. 51, figs. 2-6, 12, 14, 18-19, 23-25.

Lenticulina guttata guttata (Ten Dam). - BARTENSTEIN and BRAND 1951, pl. 5, fig. 116.

Description: Flattened, carinate test with a tendency to become evolute. Sutures are marked by prominent carinae or nodulose rows. Very ornamented forms may be tricarinate with additional longitudinal ornamentation on the chamber walls. Elaborate, phyaline, radiate aperture at end of a narrow protuding neck.

Remarks: Closely resembles more ornamented forms illustrated by Neagu (1975) but generally more flattened with a more elaborate aperture. Less involute and more flattened than specimens illustrated by Bartenstein and Brand (1951).

Range and Occurrence: Late Valanginian-early Hauterivian in northwestern Germany (Bartenstein and Brand 1951). Hauterivian in Rumania (Neagu 1975). Late Valanginian-early Barremian in Tethyan and transitional boreal facies of northern Europe (Bartenstein 1977). Characterizes the upper Hauterivian assemblage at Site 766.

Lenticulina heiermanni Bettenstaedt 1952

Plate 6, figures 5a-8b

Lenticulina heiermanni BETTENSTAEDT 1952, pl. 1, fig. 9-10. BARTENSTEIN and BETTENSTAEDT 1962, tab. 18, pl. 39, fig. 1. WEIDICH 1990, pl. 20, figs. 15-16.

Description: Thick, involute test with numerous chambers (usually 10 or more). Sutures are curved, strongly raised and form a thick, irregular umbilical callus. Radiate aperture at the peripheral angle.

Remarks: Number of chambers, prominence of sutures and size of the callus vary significantly.

Range and Occurrence: Cosmopolitan species, widely recorded from the Hauterivian to lower Aptian in the Tethyan and temperate realms (Bartenstein and Kovatcheva 1982).

Lenticulina macrodisca (Reuss 1863)

Plate 6, figures 9-10b

Cristellaria macrodisca REUSS 1863 pl. 9, fig. 5a, b.

Lenticulina macrodisca (Reuss). - NEAGU 1975, pl. 45, figs. 1-16, 20; pl. 47, figs. 25-26. - WEIDICH 1990, pl. 21, figs. 1-2.

Description: Involute, strongly convex, lenticuline test with extremely large, dark, projecting umbilical disc. Sutures are curved backwards and the periphery is very sharp with a narrow keel. Aperture radiate at peripheral angle.

Remarks: Shows considerable variability (see L. muensteri Roemer).

Range and Occurrence: A cosmopolitan species, widely distributed in the Early Cretaceous (Weidich 1990)

Lenticulina muensteri (Roemer 1839)

Plate 6, figure 11a, 11b

Robulina muensteri ROEMER 1839, pl. 20, fig. 29a, b.

Lenticulina muensteri (Roemer). - JENDRYKA-FUGLEWICZ 1975, pls. 8, 9, 10, 11, figs. 1-6, pl. 19, pl. 20, figs. 1-2. - BARTENSTEIN and BOLLI 1986, pl. 4, figs. 25-26.

Description: Smooth, involute, convex, lenticuline test with 7-12 chambers in the last whorl. Flush, markedly curved sutures coalesce into a large, dark, slightly projecting umbonal disc. Sharp periphery, radiate aperture at peripheral angle.

Remarks: This very long ranging, cosmopolitan species shows considerable variability. Jendryka-Fuglewicz (1975) has distinguished six morphotypes with stratigraphic significance from the Jurassic to the Albian in Poland. Transitional forms lead to a wide overlap and stratigraphic resolution depends on morphometric analysis. Bartenstein and Bolli (1986) have also emphasized the difficulty in dividing $L$. muensteri Roemer, L. cultrata Montfort, 
L. rotulata Lamarck, $L$. macrodisca Reuss, $L$. roemeri Reuss and $L$. subalata Reuss into valid morphological and stratigraphical groups because so many transitional forms exist. Meyn and Vespermann (1994) treat $L$. ehrenbergi, L. crassa, L. impressa and $L$. macrodisca as synonyms. At Site 766 extreme members of the $L$. muensteri and L. macrodisca plexus are distinguishable, and more refined morphological and stratigraphical resolution might be achieved with the application of morphometrics.

Range and Occurrence: A cosmopolitan species in the JurassicCretaceous (Jendryka-Fuglewicz 1975).

Lenticulina nodosa (Reuss 1863)

Plate 7 , figure $2 a, 2 b$

Robulina nodosa REUSS 1863, pl. 9, fig. 6a, b.

Lenticulina nodosa nodosa (Reuss). - BARTENSTEIN 1974b, pl. 1, figs. 3-17; pl. 2, figs. 5-6, 9-12, 16-17.

Lenticulina nodosa (Reuss). - JENDRYKA-FUGLEWICZ 1975, pl. 12, figs. 4-12.

Description: Small, involute, test with 7-10 chambers in last whorl separated by thick, curved, raised sutures. Peripheral knot-like thickenings give the test a distinctive polygonal appearance. Radiate aperture at peripheral angle.

Remarks: Uncommon at Site 766 , most tests only have weak sculpture and faint thickenings at the periphery in comparison with the plesiotypes of Bartenstein and Brand (1951) and Bartenstein and Kaever (1973). The variability of the species and its tendency to uncoil has led to considerable taxonomic confusion. Bartenstein (1974b) and Aubert and Bartenstein (1976) have identified within the $L$. nodosa Reuss plexus several subspecies and closely related species of stratigraphic and/or biogeographic relevance. Some evolute specimens are present at Site 766. Their small number and poor preservation, however, prevent subspecific identification.

Range and Occurrence: Widely distributed, but with very variable stratigraphic occurrence. This species probably embraces several iterative forms that evolved in geographic isolation from a longranging common ancestor such as Lenticulina muensteri Roemer (Michael 1967, Bartenstein 1974b, Aubert and Bartenstein 1976, Weidich 1990). Occurs from the late Jurassic to the late Aptian in Tethys, generally restricted to the Valanginian and Hauterivian in north and south temperate realms (Bartenstein 1974b, King et al. 1989).

\section{Lenticulina ouachensis (Sigal 1952)}

Plate 7, figures 10-12

Lenticulina ouachensis SIGAL 1952, Abb. 10.

Lenticulina ouachensis ouachensis (Sigal). - BARTENSTEIN and BETTENSTAEDT 1962, pl. 38, fig. 11. - WEIDICH 1990, pl. 19, fig. 17-21; pl. 42 , fig. 6 .

Description: Involute test with 8-10 moderately inflated chambers in last whorl. Carinate periphery; slightly arched, carinate sutures, attenuated near the periphery and joining in the center to form a periumbilical ring. Radiate aperture at peripheral angle.

Remarks: Partial dissolution has obliterated the sculpture on many tests from Site 766. Lenticulina ouachensis Sigal was placed in synonymy with $L$. quenstedti Gümbel by Riegraf and Luterbacher (1989b), who believe that the two species cannot be differentiated taxonomically but differ only in their stratigraphic ranges. They also pointed out that this species has been described under many different names (see synonymy list in Riegraf and Luterbacher 1989b).
Range and Occurrence: Lenticulina ouachensis Sigal is a cosmopolitan species with a range from Berriasian to Aptian (Riegraf and Luterbacher 1989a, Weidich 1990). Lenticulina quenstedti Gümbel extends from the Bajocian to the late Tithonian.

Lenticulina pulchella (Reuss 1863)

Plate 7, figures $4 a-5 b$

Cristellaria pulchella REUSS 1863, pl. 8, fig. 1.

Lenticulina pulchella (Reuss). - JENDRYKA-FUGLEWICZ 1975, pl. 13, figs. 5-7.

Description: Involute test tending to uncoil, usually, with eight chambers increasing rapidly in size in last whorl. Fine, curved sutures, flush and indistinct in early part, becoming depressed. Last chamber pointed towards terminal, radiate aperture. Small, depressed umbilicus, acute periphery and oval to polygonal outline.

Range and Occurrence: Occurs in the Valanginian-Hauterivian of Poland and in the Albian of Germany and Rumania (JendrykaFuglewicz 1975).

\section{Lenticulina saxocretacea Bartenstein 1954}

Plate 7, figure 3

Lenticulina saxocretacea BARTENSTEIN 1954, p. 45-46.

Cristellaria subalata REUSS 1863, pl. 8, fig. 10; pl. 9, fig. 1.

Lenticulina saxocretacea Bartenstein. - BARTENSTEIN and BOLLI 1986, pl. 4, figs. 32-34. - WEIDICH 1990, pl. 21, fig. 7, pl. 41, figs. 23-26; pl. 42 , figs. 1, 7-8, 11.

Description: Robust involute to slightly evolute test with 7-10 chambers in last whorl and a sharp, carinate periphery. Sutures limbate, raised and curved. Umbilical disc flush and poorly defined. Radiate aperture near dorsal margin.

Remarks: The Early Cretaceous form of L. subalata Reuss 1863 was renamed $L$. saxocretacea by Bartenstein (1954) to differentiate it from the Late Cretaceous homonym L. subalata Reuss 1854. Lenticulina subalata Reuss 1854 differs from L. saxocretacea Bartenstein mainly in having a larger, better defined, rounded callus and a more convex profile and narrower keel (see also L. muensteri Roemer). Lenticulina saxocretacea Bartenstein and L. subalata Reuss were both illustrated by Weidich (1990).

Range and Occurrence: Lenticulina saxocretacea Bartenstein ranges from Barremian to Albian in boreal and Tethyan realms (Bartenstein and Bolli 1986). Lenticulina subalata Reuss 1854 ranges from the Berriasian to the Late Cretaceous (Weidich 1990).

Lenticulina cf. schreiterei (Eichenberg 1935)

Elphidium schreiterei EICHENBERG 1935, pl. 13, fig. 11.

Lenticulina d'Orbigny schreiterei (Eichenberg). - BARTENSTEIN and BRAND 1951, pl. 4, figs. 104-105.

Lenticulina schreiterei (Eichenberg). - BARTENSTEIN and KAEVER 1973, pl. 2, fig. 31.

Description: Involute, relatively flattened test tending to uncoil with prominent, irregular, longitudinal ribs. Sutures indistinct, periphery sharply carinate, aperture at peripheral angle.

Remarks: Very rare at Site 766. Bartenstein and Brand (1951) defined L. schreiterei Eichenberg as a subspecies of the Jurassic species $L$. d'Orbigny Roemer, recently redefined by Brand and Ohmert (1992). Lenticulina schreiterei Eichenberg is often confused in the literature with the very variable species $V$. reticulosa Ten Dam, the taxonomic parameters separating these two species being rather obscure. Specimens in Site 766 differ from L. schreiterei Eichenberg by their heavier, irregular ornamentation and less 
inflated chambers; the identification of these specimens as $L$. schreiterei Eichenberg remains tentative as a taxonomic and stratigraphic reappraisal of $L$. schreiterei Eichenberg and V. reticulosa Ten Dam is needed to clarify the confusion between these two species.

Range and Occurrence: Late Valanginian-early Hauterivian in northwestern Germany (Bartenstein and Brand 1951).

Lenticulina subangulata (Reuss 1863)

Plate 8, figure 1a, $1 \mathrm{~b}$

Cristellaria subangulata Reuss 1863; pl. 8, fig. 7.

Lenticulina subangulata (Reuss). - BARTENSTEIN and BRAND 1951, pl. 5, fig. 111. - JENDRYKA-FUGLEWICZ 1975, pl. 13, figs. 8-9. MOULLADE 1984, pl. 3, fig. 3.

Description: Large, robust, involute, lenticuline test with an acute periphery (no keel). Sutures are fine, inclined backwards and faintly raised. The last two chambers become elongated and sharply angled, giving the test its distinctive angular outline. Radiate aperture at peripheral margin.

Range and Occurrence: Common in the Valanginian-Hauterivian of Europe (Jendryka-Fuglewicz 1975).

Lenticulina cf. subgaultina Bartenstein 1962

Plate 8, figure $4 a, 4 b$

Lenticulina cf. subgaultina BARTENSTEIN 1962, pl. 15, figs. 1-2.

Lenticulina subgaultina Bartenstein. - BARTENSTEIN, BETTENSTAEDT and BOLLI 1966, pl. 2, figs. 128-129. - NEAGU 1975, pl. 49 , figs. 3-17, 19, 21-22, 24, 27-28, 32; pl. 50, fig. 20.

Description: Involute test tending to uncoil with an elongated last chamber. Sutures flush or depressed, distinct umbilical disc and sharp periphery with or without carina.

Remarks: Taxonomic descriptions vary significantly. Specimens from Site 766 are poorly preserved and have only been tentatively identified.

Genus Marginulinopsis A. Silvestri 1904

Marginulinopsis bettenstaedti Bartenstein and Brand 1951 Plate 8, figures 7-9

Marginulinopsis bettenstaedti BARTENSTEIN and BRAND 1951, pl. 6, figs. 144-147. - RIEGRAF 1989, pl. 1, fig. 27.

Description: Elongated test with small, planispirally coiled stage becoming evolute. Uncoiled stage consists typically of three chambers. Chambers increase markedly in size, becoming very inflated ventrally. Sutures are depressed and straight. Aperture terminal. Periphery carinate. Surface of test ornamented by prominent longitudinal costae (usually eight per side), often becoming offset at sutures.

Range and Occurrence: First described from Valanginian deposits of northwestern Germany (Bartenstein and Brand 1951), this species is widely recorded in the Early Cretaceous: from Kimmeridgian to Albian in California, the North Atlantic, the Paris Basin, northern Germany, Sardinia, Madagascar and from the Kimmeridgian to Hauterivian in western Indian Ocean (Riegraf 1989).

Marginulinopsis comma (Roemer 1841)

Plate 8 , figure $5 \mathrm{a}, 5 \mathrm{~b}$

Marginulina comma ROEMER 1841, pl. 15, fig. 15.
Marginulinopsis comma (Roemer). - BARTENSTEIN and BRAND 1951, pl. 6, fig. 135. - FUCHS and STRADNER 1967, pl. 11, fig. 7.

Description: Elongated test with clearly defined planispiral early portion and evolute stage, usually consisting of four broad chambers becoming more elongated and inflated distally. The last chamber is drawn out towards a terminal, dorsal aperture. Sutures are deeply depressed, dorsal and ventral margins rounded without keels.

Range and Occurrence: Reported from the middle and upper Valanginian of northwestern Germany by Bartenstein and Brand (1951) and from the Hauterivian of Germany by Roemer (1841).

Marginulinopsis gracilissima (Reuss 1863)

Plate 8, figures 11-13

Cristellaria gracilissima REUSS 1863, pl. 6, figs. 9-10.

Marginulinopsis gracilissima (Reuss). - BARTENSTEIN and BRAND 1951, pl. 6, fig. 139. - FOWLER and BRAUN 1993, pl. 7, figs. 36-39.

Description: Elongated hispid test with curved axis and well defined planispiral early stage. Three chambers in the evolute portion become elongated and inflated, the last one tapering towards an apertural neck on the dorsal side. Sutures are distinctly depressed and periphery round.

Remarks: Closely resemble specimens illustrated by Fowler and Braun (1993).

Range and Occurrence: Widely recorded in the Lower Cretaceous deposits of Europe and the Hauterivian-Barremian of the Mount Goodenough Formation in Canada (Fowler and Braun 1993).

Marginulinopsis parkeri (Reuss 1863)

Marginulina parkeri REUSS 1863 pl. 5, fig. 14.

Marginulinopsis parkeri (Reuss). - BARTENSTEIN and BRAND 1951, pl. 6, figs. 136-137. - NEAGU 1975, pl. 60, figs. 12, 14.

Description: Elongated test, oval in cross-section with planispiral early stage, becoming evolute and rectilinear. Chambers inflated, becoming more elongated with sutures depressed and inclined, periphery rounded without keel, radiate aperture at peripheral angle.

Remarks: Very similar to specimens illustrated by Neagu (1975).

Range and Occurrence: Late Valanginian-early Hauterivian in northwestern Germany (Bartenstein and Brand 1951) and in Rumania (Neagu 1975).

Genus Saracenaria Defrance 1824

Saracenaria compacta Espitalié and Sigal 1963

Plate 8, figures 6a, 6b, 10a, 10b.

Saracenaria compacta ESPITALIÉ and SIGAL 1963, pl. 24, figs. 4-5. SLITER 1980, pl. 12, fig. 4. - KUZNETSOVA and SEIBOLD 1977, pl. 7, fig. 12.

Description: Thick, massive, triangular test with few chambers separated by prominent raised, curved sutures. The ventral and dorsal margins are carinate and the oral face forms an angle of approximately $90^{\circ}$ with the ventral face. Radiate aperture at peripheral angle.

Remarks: Espitalié and Sigal (1977) suggested that $S$. compacta evolved from forms of $S$. pravoslavlevi Fursenko and Polenova, or $S$. tsaramandrosoensis Espitalié and Sigal. Transitional forms 
from Saracenaria pravoslavlevi Fursenko and Polenova are observed at Site 766. Saracenaria compacta differs from $S$. forticosta Bettenstaedt mainly by the very marked angle between the oral and ventral faces. One of the $S$. forticosta paratypes from the middle Barremian of northwestern Germany (Bettenstaedt 1952) resembles $S$. compacta Espitalié and Sigal very closely and is probably a representative of that species (Espitalié and Sigal 1963).

Range and Occurrence: First described from the Berriasian-Barremian in the Majunga Basin of Madagascar by Espitalié and Sigal (1963). Also recorded in the eastern North Atlantic (Sliter 1980).

Saracenaria erlita Ludbrook 1966

Plate 9, figure $8 \mathrm{a}, 8 \mathrm{~b}$

Saracenaria erlita LUDBROOK 1966, pl. 8, fig. 10. - SCHEIBNEROVÁ 1974b, pl. 2, figs, 25-26. - SCHEIBNEROVÁ 1976, text-figs. 84-85.

Description: Triangular test with rounded ventral edges and sharper dorsal edge (no keel). Six or seven chambers planispirally coiled, except for the last one which becomes strongly inflated ventrally. Sutures curved and slightly depressed, radiate aperture at peripheral angle

Remarks: This species is close to $S$. bronnii Roemer but lacks its longer evolute portion.

Range and Occurrence: Recorded from the Aptian in South Australia and the eastern Indian Ocean (Scheibnerová 1974; 1976).

Saracenaria forticosta Bettenstaedt 1952

Plate 9, figures 1-7

Saracenaria forticosta BETTENSTAEDT 1952, pl. 1, fig. 12; pl. 2, fig. 13. Saracenaria italica Defrance var. crassicosta EICHENBERG 1933, pl. 5, fig. 2a-c.

Saracenaria crassicosta Eichenberg. - RIEGRAF 1989, pl. 1, fig. 18.

Description: Large, broad, triangular test with straight or slightly curved axis and numerous chambers (nine or more). It has a small planispiral stage and a well-developed evolute portion. Low and broad chambers are separated by curved, strongly raised sutures. The dorsal edge is carinate and the ventral edges sharply angled. Last chamber very triangular, slightly inflated ventrally and drawn out towards terminal radiating aperture.

Remarks: This species may be confused with $S$. pravoslavlevi Fursenko and Polenova. Although Bartenstein $(1977,1979)$ has queried the separation of these two species, their different stratigraphic ranges and morphologies suggest that they should be treated separately. Saracenaria forticosta Bettenstaedt may have evolved from $S$. pravoslavlevi Fursenko and Polenova, rather than from $S$. frankei Ten Dam as suggested by Bartenstein (1978).

Range and Occurrence: First described from the middle Barremian of northwestern Germany (Bettenstaedt 1952), it has been widely recorded from Berriasian to Albian in California, the North Atlantic, Europe, Madagascar and the eastern and western Indian Ocean (Riegraf 1989).

\section{Saracenaria frankei Ten Dam 1946}

Plate 9, figures 9-10b

Saracenaria frankei TEN DAM 1946, pl. 8, fig. 1a, b. - BARTENSTEIN and BOLLI 1977, pl. 2, figs. 9-10. - SLITER 1980, pl. 12, figs. 8-9. WEIDICH 1990, pl. 24, fig. 6.

Description: Elongated, triangular test with small, enrolled, early portion and well developed evolute stage. Ventral and dorsal edges of test markedly angular; numerous, low, broad chambers separated by distinct curved sutures; last chamber elongated towards radiating aperture at peripheral angle.

Remarks: Also close to $S$. lutanata Ludbrook recorded from Valanginian to Albian in eastern and western Indian Ocean (Riegraf 1989).

Range and Occurrence: A cosmopolitan species common in Tethyan and temperate facies deposits from the Valanginian to Aptian (Bartenstein 1977), in the eastern North Atlantic (Sliter 1980) and in northern alpine sediments from the Hauterivian to Barremian (Weidich 1990).

Saracenaria pravoslavlevi Fursenko and Polenova 1950 Plate 9, figures 11a-13

Saracenaria pravoslavlevi FURSENKO and POLENOVA 1950, pl. 4, figs. 13-15. - ESPITALIÉ and SIGAL 1963, pl. 23, figs. 4-7; pl. 24, fig. 1. FOWLER AND BRAUN 1993, pl. 8, figs. 13-15.

Description: Triangular test with very prominent carinae along dorsal and ventral margins. Broad, raised, thickened sutures on dorsal side becoming narrower and slightly depressed on ventral side, aperture radiate at peripheral angle. Tests exhibit considerable variation in length, degree of curvature and spine development. Differences in ornamentation are also observed as keels may be acute and jagged and sutures vary in regularity and convexity.

Remarks: S. pravoslavlevi Fursenko and Polenova has many variants and transitional forms to other Saracenaria species are found.

Range and Occurrence: First described from lower Volgian deposits of the Emba region in the former U.S.S.R. by Fursenko and Polenova, this is a cosmopolitan species found in Lower Cretaceous deposits of the Majunga Basin, Madagascar (Espitalié and Sigal 1963) and the Mount Goodenough Formation, Aklavik Range, North America (Fowler and Braun 1993).

Saracenaria spinosa (Eichenberg 1935)

Plate 10 , figure $2 \mathrm{a}, 2 \mathrm{~b}$

Lenticulina spinosa EICHENBERG 1935, pl. 4, fig. 5a-d.

Saracenaria spinosa (Eichenberg). - TAPPAN 1962, pl. 41, figs. 18-19. - BARTENSTEIN and KAEVER 1973, pl. 6, fig. 94. - WEIDICH 1990, pl. 42, figs. 14-15.

Description: Triangular test, composed of few low chambers (usually six or seven), strongly involute except for the last two chambers. Last chamber inflated and flaring markedly towards a radiate aperture; sutures slightly depressed. Periphery acute with a thin keel along the dorsal margin in the early chambers. Chambers are characteristically extended by needle-shaped spines along the ventral edges of the last two chambers.

Remarks: The specimen illustrated by Bartenstein and Kaever (1973, pl. 6, fig. 94) was found to differ markedly from the specimens from Site 766 in its straighter, longer evolute portion and a reduced planispiral stage. It is also generally less inflated and lacks sharp spines (instead of true spines, it has rounded projections along the ventral edges of the evolute chambers). The specimen illustrated by Weidich (1990) is also more evolute and its spines are not well defined. Moullade (pers. comm., 1994) also found this specimen to differ from the typical Aptian-Albian Tethyan forms.

Range and Occurrence: First described from Aptian deposits in north Germany, this is a cosmopolitan species recorded from the upper Aptian of the northern Alps (Weidich 1990), the upper Aptian-lower Albian of the Vocontian Trough (Moullade 1966) and 
in many parts of the world from the Aptian to lower Albian (Bartenstein and Kaever 1973; Bartenstein 1979).

Saracenaria triangularis (d'Orbigny 1840)

Plate 10 , figure $1 \mathrm{a}, 1 \mathrm{~b}$

Saracenaria triangularis d'ORBIGNY 1840, pl. 2, figs. 21-22. - FUCHS and STRADNER 1967, pl. 12, fig. 3. - MOULLADE 1984, pl. 3, fig. 1.

Description: Involute triangular test with thin dorsal keel and sharp ventral edges. Six or seven chambers, low and wide becoming very inflated, last chamber flaring to pointed radiate aperture, oblique sutures strongly curved and slightly depressed.

Remarks: Also bears some resemblance to $S$. brookei Fowler and Braun from Hauterivian-Barremian of Mount Goodenough Formation of Canada.

Range and Occurrence: A cosmopolitan species recorded from Albian deposits of the Atlantic and Tethys (Moullade 1984) and in Holland (Fuchs and Stradner 1967).

Saracenaria valanginiana Bartenstein and Brand 1951

Plate 10, figures $4 a-6$.

Saracenaria valanginiana BARTENSTEIN and BRAND 1951, pl. 13, figs. 364-365. - TAPPAN 1962, pl. 42, figs. 7-8.

Description: Triangular test, elongated, with a small planispiral stage. Chambers broader than high, separated by thin, slightly depressed, curved sutures. Characteristic ornamentation consisting of thin, irregular, longitudinal striations on ventral and dorsal sides of test; striations usually reach the base of the last chamber but their number and prominence may vary considerably.

Remarks: Some forms from Site 766 are shorter and squatter with a larger involute stage and stronger costae than the holotype of Bartenstein and Brand (1951, pl. 10, fig. 6) and with a very prominent central parting on the ventral side. The form illustrated by Tappan (1962) from the Albian appears to have much finer ornamentation and may not be similar to the Valanginian form. Ludbrook (1966) also described the new species Saracenaria warella from the Aptian-Albian of the Great Australian Basin which resembles Saracenaria valanginiana.

Range and Occurrence: First described from Valanginian deposits of northwestern Germany, this is a cosmopolitan species widely recorded in Berriasian to Valanginian Tethyan and temperate facies deposits (Bartenstein 1979) and in Berriasian-Valanginian sediments along the Atlantic margin of North America (Ascoli 1988). In the Arctic it was found by Tappan (1962) in the Albian.

\section{Saracenaria sp.1,}

Plate 10, figure 10a, $10 \mathrm{~b}$.

Description: Very elongated, slender, triangular test with numerous chambers (more than 12) arranged along a slightly curved axis; enrolled portion very reduced. Distinct, curved sutures on dorsal side, slightly depressed on ventral side, sharp keels along dorsal and ventral edges. Last chamber tapering towards radiate terminal aperture.

Remarks: Only one complete test found plus fragments. The test appears very fragile. Reminiscent of Saracenaria yalanya Ludbrook (cf. Ludbrook 1966; pl. 8, fig. 15) but the test of our specimen remains very narrow and has more chambers in its uncoiled portion.

\section{Saracenaria sp. 2,}

Plate 10, fig. 11

Description: Elongated, narrow test without a distinct coil and without ornamentation, becoming rectilinear and triangular in cross-section. Chambers low, separated by distinct, strongly oblique sutures. Last chamber tapering towards radiating aperture at dorsal angle.

Remarks: Rare at Site 766. Reminiscent of Saracenaria cf. grandstandensis Tappan (cf. Tappan 1962; pl. 41, figs. 3-5).

Saracenaria sp.

Plate 10, figures 7-9

\section{PLATE 1}

la,b Bathysiphon brosgei Tappan, $(\times 85, \times 80)$, Sample 766A30R-04; 100-102cm.

2 Rhizammina sp., (×65), Sample 766A-48R-04; 51$54 \mathrm{~cm}$.

3 Rhabdammina cylindrica Glaessner, $(\times 80)$, Sample 766A-48R-04; 51-54cm.

4 Rhabdammina cylindrica Glaessner, $(\times 100)$, Sample 766A-48R-04; 51-54cm.

5 Rhizammina algaeformis Brady, $(\times 50)$, Sample 766A46R-03; $122-125 \mathrm{~cm}$.

6a,b Ammodiscus tenuissimus (Gümbel), $(\times 180, \times 180)$, Sample 766A-48R-04; 51-54cm.

7 Ammodiscus cretaceus (Reuss), $(\times 130)$, Sample 766A28R-03; 116-120cm.
8 Ammodiscus cretaceus (Reuss), $(\times 100)$, Sample 766A30R-04; 100-102cm.

9 Ammodiscus sp., (×130), Sample 766A-28R-05; 133$138 \mathrm{~cm}$.

10 Glomospirella gaultina (Berthelin), $(\times 100)$, Sample 766A-30R-04; 100-102cm.

11 Glomospirella gaultina (Berthelin), $(\times 90)$, Sample 766A-47R-04; 114-119cm.

12 Glomospirella gaultina (Berthelin), $(\times 55)$, Sample 766A-28R-01; 21-25cm.

13 Glomospira charoides charoides (Jones and Parker), (×120), Sample 766A-28R-01; 21-25cm. 


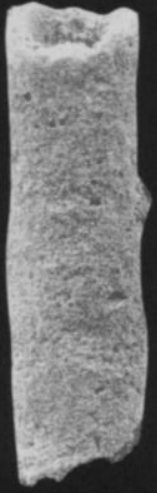

1 a

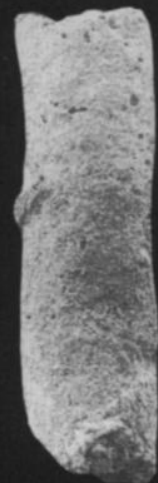

$1 \mathrm{~b}$

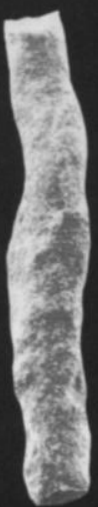

2

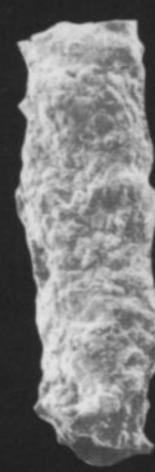

3

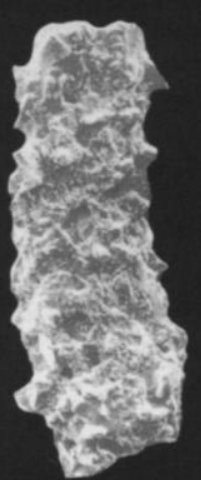

4

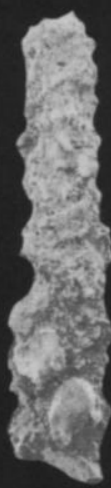

5
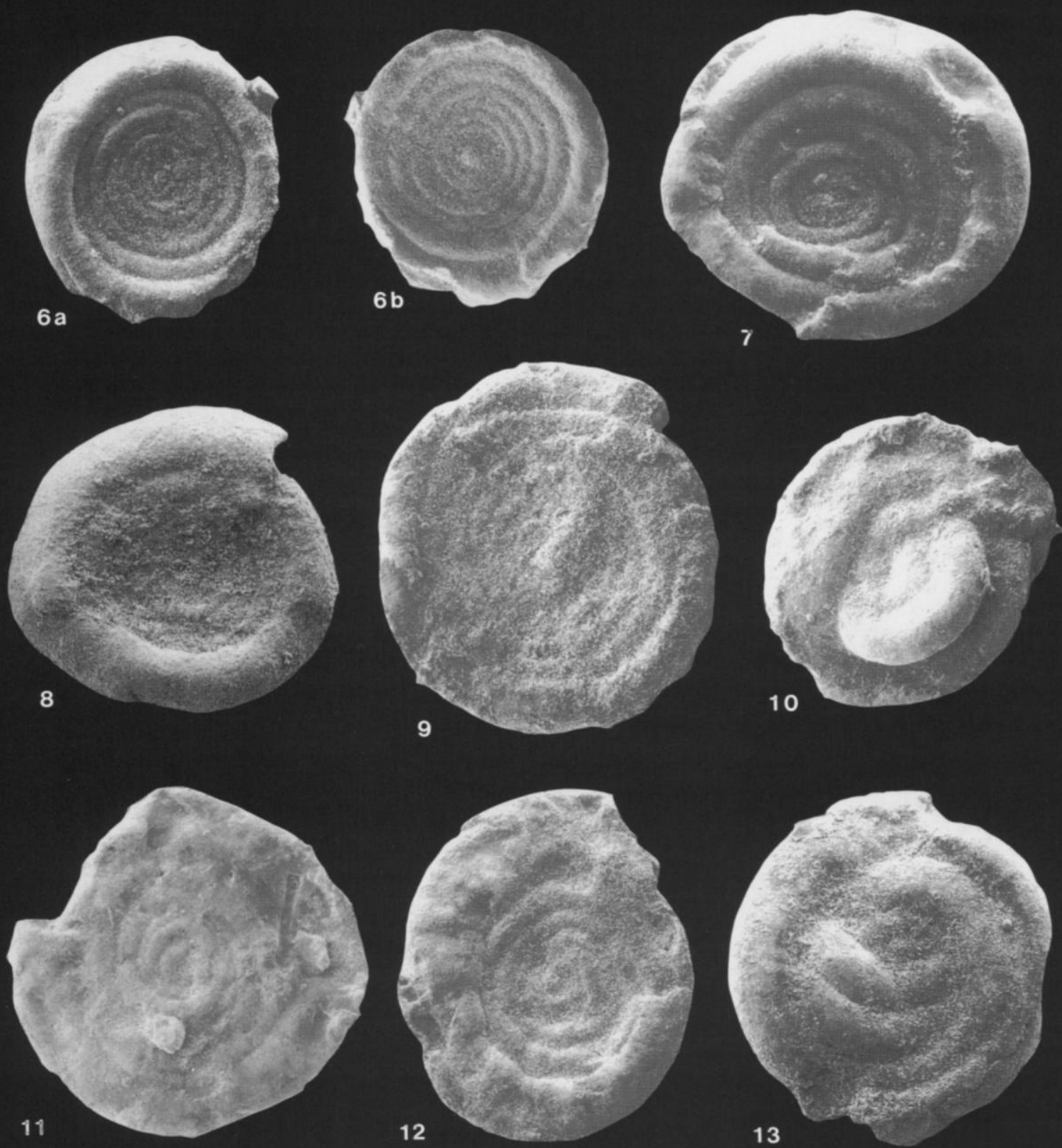
Description: Elongated, smooth, tapering test but with broader chambers than Saracenaria sp. 1. May be a transitional form.

Subfamily PALMULINAE Saidova 1981

Genus Palmula Lea 1883

Palmula sp. 1

Plate 11, figure 1a, $1 \mathrm{~b}$.

Falsopalmula cf. obliqua Terquem. - BARTENSTEIN and BRAND 1951, pl. 8, fig. 197.

Falsopalmula cf. deslongchampsi Terquem. - KUZNETSOVA and SEIBOLD 1977, pl. 1, fig. 17.

Description: Large, elongated, flattened test, planispiral initially becoming uncoiled and slightly flaring with a subrounded periphery. Low, broad chambers are separated by strongly arched, thick, flush sutures. Terminal, radiate aperture.

Remarks: Rare at Site 766. Bartenstein and Brand's species has a broader, squatter shape whereas Kuznetsova and Seibold's is longer with more chambers than specimens from Site 766. This species is also reminiscent of $P$. primordialis Terquem, illustrated by Riegraf and Luterbacher (1989b) but lacks its sharper periphery and raised sutures.

Subfamily MARGINULININAE Wedekind 1937

Genus Astacolus de Montfort 1808

Astacolus calliopsis (Reuss 1863)

Plate 11, figures 2a-5

Marginulina linearis REUSS 1863, pl. 5, fig. 15.

Astacolus calliopsis (Reuss). - BARTENSTEIN and BRAND 1951, pl. 5, figs. 120-122. - BARTENSTEIN and BOLLI 1986, pl. 4, figs. 9-10.

Description: Elongated test with small planispiral portion and slightly curved axis. Chambers few, compressed dorsally, last one becoming more inflated and tapering towards radiate, terminal aperture. Sutures slightly depressed and strongly inclined.

Remarks: Shows variability in width, height and degree of compression of the chambers.
Range and Occurrence: A cosmopolitan species, widely recorded from the Lower Cretaceous (Bartenstein and Bolli 1986).

Astacolus schloenbachi (Reuss 1863)

Plate 11, figure 6a, 6b

Cristellaria schlönbachi REUSS 1863, pl. 6, figs. 14-15.

Astacolus schlönbachi (Reuss). - BARTENSTEIN and BRAND 1951, pl.

5, figs. 124-125. - BARTENSTEIN and BOLLI 1986, pl. 4, figs. 35-36.

Description: Elongated test with slightly curved axis. Chambers somewhat irregular in size and less compressed than in S. calliopsis Reuss; early chambers not forming full spiral, last chamber drawn out towards a radiate terminal aperture, sutures depressed and strongly inclined.

Range and Occurrence: a cosmopolitan species, widely distributed throughout the Lower Cretaceous (Bartenstein and Bolli 1986).

Genus Marginulina d'Orbigny 1826

Marginulina bullata Reuss 1860

Plate 11, figure 7a, 7b

Marginulina bullata REUSS 1860, pl. 6, figs. 4-6. - SCHEIBNEROVÁ 1976, pl. 29, fig. 1. - BARTENSTEIN and BOLLI 1986, pl. 5, figs. 17-18.

Description: Elongated, robust test with broad chambers, slightly coiled initially becoming evolute. Last chamber very inflated and bearing a radiate, terminal aperture at the dorsal edge, sutures oblique and slightly depressed.

Remarks: Site 766 specimens differ from those illustrated by Reuss (1860) and Bartenstein and Bolli (1986) in having fewer chambers and more oblique sutures.

Range and Occurrence: Upper part of the Lower Cretaceous and Cenomanian of northern California (Bartenstein and Bolli 1986).

Marginulina inaequalis Reuss 1860

Plate 11, figure 12

Marginulina inaequalis REUSS 1860, pl. 7. fig. 3. - RIEGRAF 1989, pl. 2, figs. 6-7. 1a,b Glomospira charoides corona Cushman and Jarvis, $(\times 200, \times 190)$, Sample 766A-30R-03; 100-102cm.

2 Haplophragmoides kirki Wickenden, $(\times 145)$, Sample 766A-47R-04; 114-119cm.

3a,b Glomospira charoides corona Cushman and Jarvis, $(\times 160, \times 150)$, Sample 766A-29R-03; 54-58cm.

4 Haplophragmoides vocontianus Moullade, $(\times 130)$, Sample 766A-49R-02; 42-46cm.

5 Haplophragmoides concavus (Chapman), (×105), Sample 766A-47R-01; 98-103cm.
6 Haplophragmoides sp. 1, $(\times 140)$, Sample 766A-48R$02 ; 95-98 \mathrm{~cm}$.

7 Haplophragmoides concavus (Chapman), $(\times 130)$, Sample 766A-47R-04; 114-119cm.

8a,b Ammobaculites sp. 1, $(\times 80, \times 75)$, Sample 766A-48R02; 95-98cm.

$9 \quad$ Bulbobaculites sp. 1,(×75), Sample 766A-44R-05; 102$106 \mathrm{~cm}$.

10 Bulbobaculites inconstans erectum (Bartenstein and Brand), (×85), Sample 766A-49R-01; 124-128cm. 


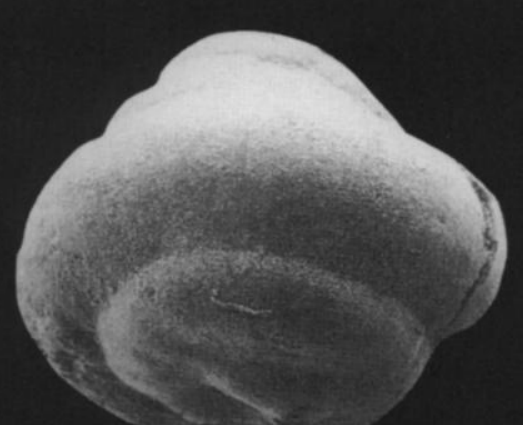

1 a

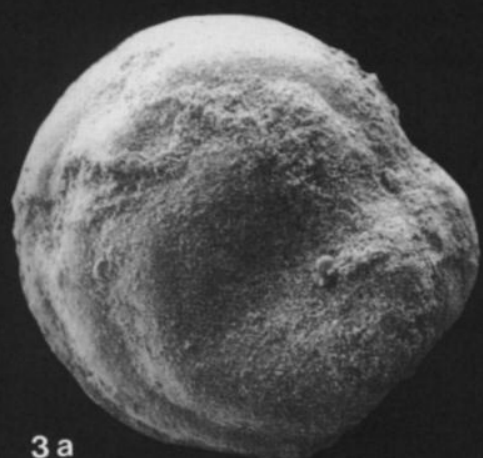

3 a
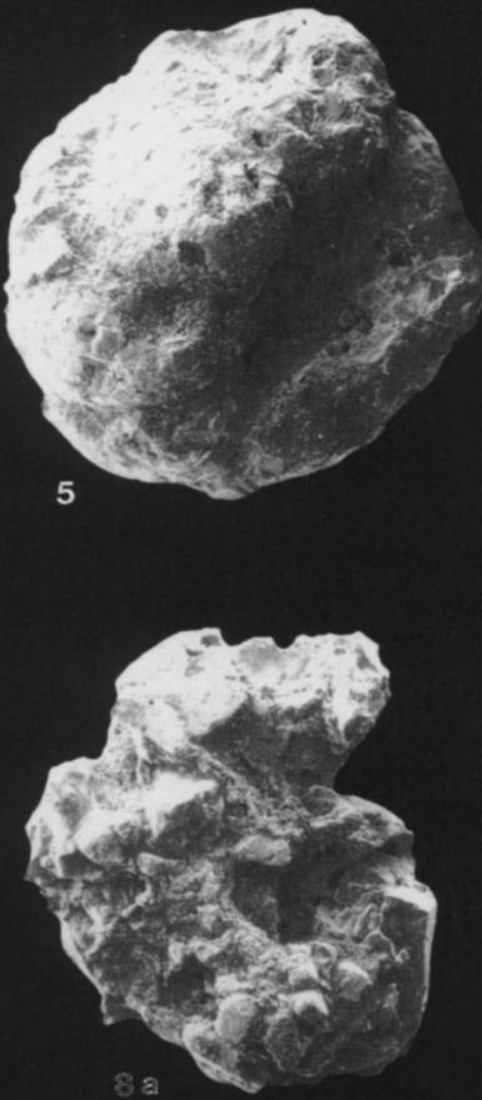
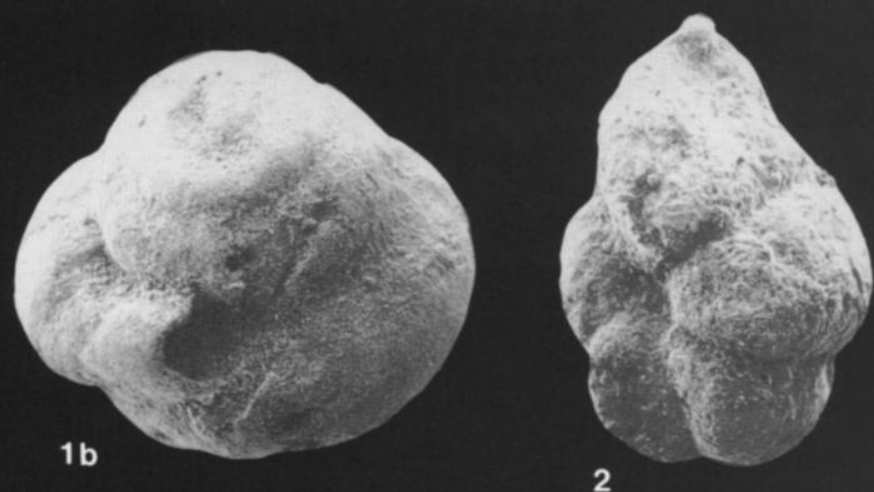

2

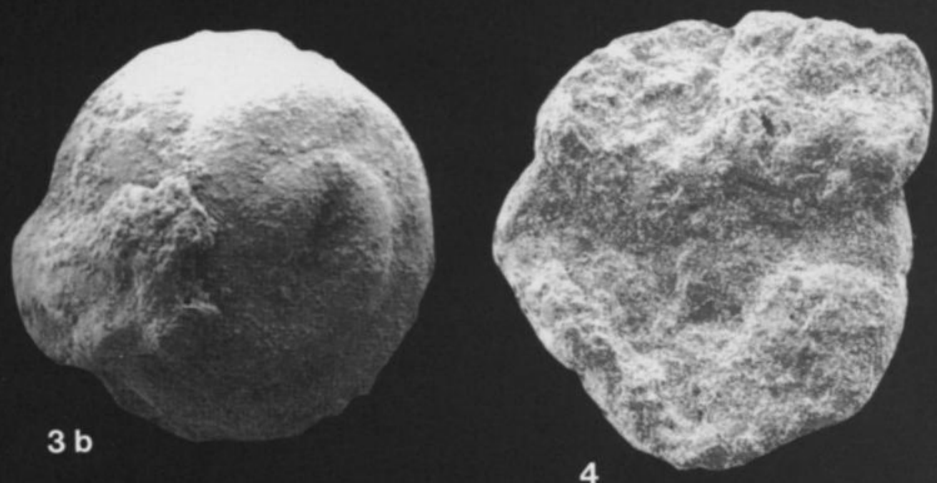

4

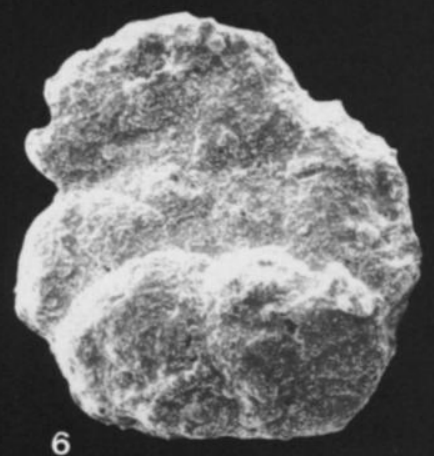

6

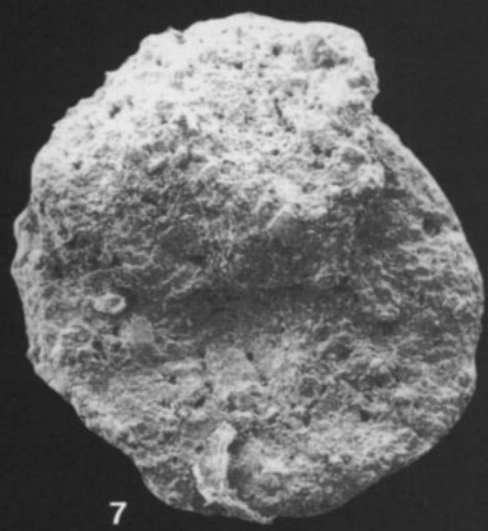

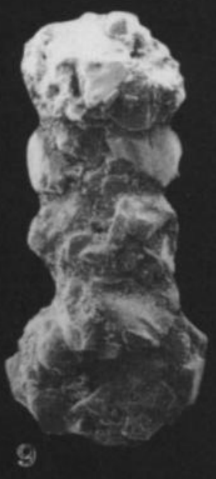

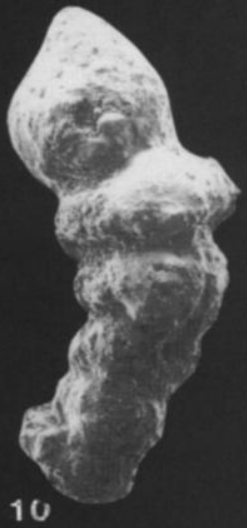


Marginulina sp. - KUZNETSOVA and SIEBOLD 1977, pl. 7, fig. 5.

Description: Elongated, straight test, slightly curved initially, with circular cross-section and chambers of irregular shape and size. First chamber rounded, slightly pointed at the proximal end. Ultimate chamber markedly inflated, drawn out towards a radiate, terminal aperture.

Remarks: Specimens from Site 766 most closely resemble forms illustrated by Kuznetsova and Siebold (1977) from the North Atlantic and by Riegraf (1989) from ODP Site 249.

Range and Occurrence: Oxfordian-Albian in the North Atlantic, Paris Basin, northern Germany, western Indian Ocean and Central Pacific (Riegraf 1989).

\section{Marginulina pyramidilis (Koch 1851)}

Plate 11, figure 10

Nodosaria pyramidilis KOCH 1851, pl. 24, fig. 8.

Marginulina pyramidilis (Koch). - BARTENSTEIN and BRAND 1951, pl. 9, figs. 221-223. - FOWLER and BRAUN 1993, pl. 7, figs. 18-19.

Description: Elongated, straight test, slightly curved initially, with apiculate or rounded base and six prominent, straight, longitudinal costae. Cross-section subcircular to circular, aperture terminal.

Remarks: Site 766 specimens are similar to plesiotypes illustrated by Bartenstein and Brand (1951) and Bartenstein and Kaever (1973).

Range and Occurrence: Most common in middle Valanginian and upper Hauterivian deposits of the boreal realm, also occurs in Berriasian-Valanginian of Siberia and throughout the Lower Cretaceous in Europe (Fowler and Braun 1993).

\section{Marginulina sp. 1}

Plate 11, figure $8 a, 8 b, 8 c$

Description: Elongated test with slightly curved axis, few inflated chambers and prominent, wide carinae along the dorsal and ventral edges. Lateral longitudinal rib, may be discontinuous and offset towards the dorsal margin in successive chambers, radiate aperture at the end of a robust, cylindrical neck on dorsal side.
Remarks: Very rare, does not match any described species in the consulted references.

Genus Vaginulinopsis Silvestri 1904

Vaginulinopsis excentrica (Cornuel 1848)

Plate 11, figures 9a, 9b, 11a, 11b; pl. 12, figures 1a, 1b, 3 .

Cristellaria excentrica CORNUEL 1848, pl. 2, figs. 11-13.

Vaginulinopsis excentrica (Cornuel). - NEAGU 1975, pl. 55, figs. 5, 8-17, 22-26. - SLITER 1980, pl. 12, figs. 21-22; pl. 13, fig. 1.

Description: Elongated test with a well-developed planispiral early portion and evolute later stage. Sutures inclined and slightly depressed, last chamber elongated towards radiate aperture at dorsal margin, periphery subrounded.

Remarks: Width of chambers and degree of evolution vary.

Range and Occurrence: Hauterivian-Aptian in Rumania (Neagu 1975).

Vaginulinopsis humilis precursoria Bartenstein and Brand 1951 Plate 12, figures $7 \mathrm{a}-8$

Vaginulinopsis humilis precursoria BARTENSTEIN and BRAND 1951, pl. 5, figs. 126-127. - BARTENSTEIN 1974a, pl. 2, figs. 28-37. NEAGU 1975, pl. 57, figs. 28-37; pl. 59, figs. 35-37.

Description: Flattened test with early planispiral portion becoming evolute and extended. Chambers low and broad, separated by curved, strongly raised, irregular sutures. Subacute dorsal margin slightly arched and unkeeled; ventral margin straight and truncated with last chamber very elongated towards a radiate aperture located at dorsal margin.

Remarks: Differs from forms illustrated by Bartenstein (1974a) by its more flattened test and discontinuous sutures (forming nodulose ridge rather than continuous ridges). Rare at Site 766, tests show variation in width and degree of tapering.

Range and Occurrence: A cosmopolitan index marker for the late Valanginian-early Hauterivian (Bartenstein 1974a). la,b Ammobaculites sp., $(\times 50, \times 50)$, Sample 766A-44R-03; $47-52 \mathrm{~cm}$.

2a,b Aaptotoichus clavellatus (Loeblich and Tappan), $(\times 105, \times 110)$, Sample 766A-49R-02; 42-46cm.

3a,b Trochammina sp. $1,(\times 105, \times 110)$, Sample 766A-47R$01 ; 88-103 \mathrm{~cm}$.

4a,b Trochammina sp. 2, $(\times 100, \times 105)$, Sample 766A-48R$04 ; 51-54 \mathrm{~cm}$.

5a,b Pseudoreophax sp.1,(×95, ×95), Sample 766A-46R-05; $20-24 \mathrm{~cm}$. 6a,b Verneuilinoides subfiliformis Bartenstein, $(\times 130$, $\times 120$ ), Sample 766A-49R-01; 124-128cm.

7 Remesella sp., $(\times 160)$, Sample 766A-29R-03; 54-58cm.

$8 \quad$ Verneuilina sp. 1, $(\times 160)$, Sample 766A-29R-03; 54$58 \mathrm{~cm}$.

9 Textularia bettenstaedti Bartenstein and Oertli, $(\times 100)$, Sample 766A-46R-05; 20-24cm.

10 Pseudogaudryinella sp. 1, (×80), Sample 766A-29R$03 ; 54-58 \mathrm{~cm}$.

11 Dorothia sp. 1, (×90), Sample 766A-29R-03; 54-58cm. 

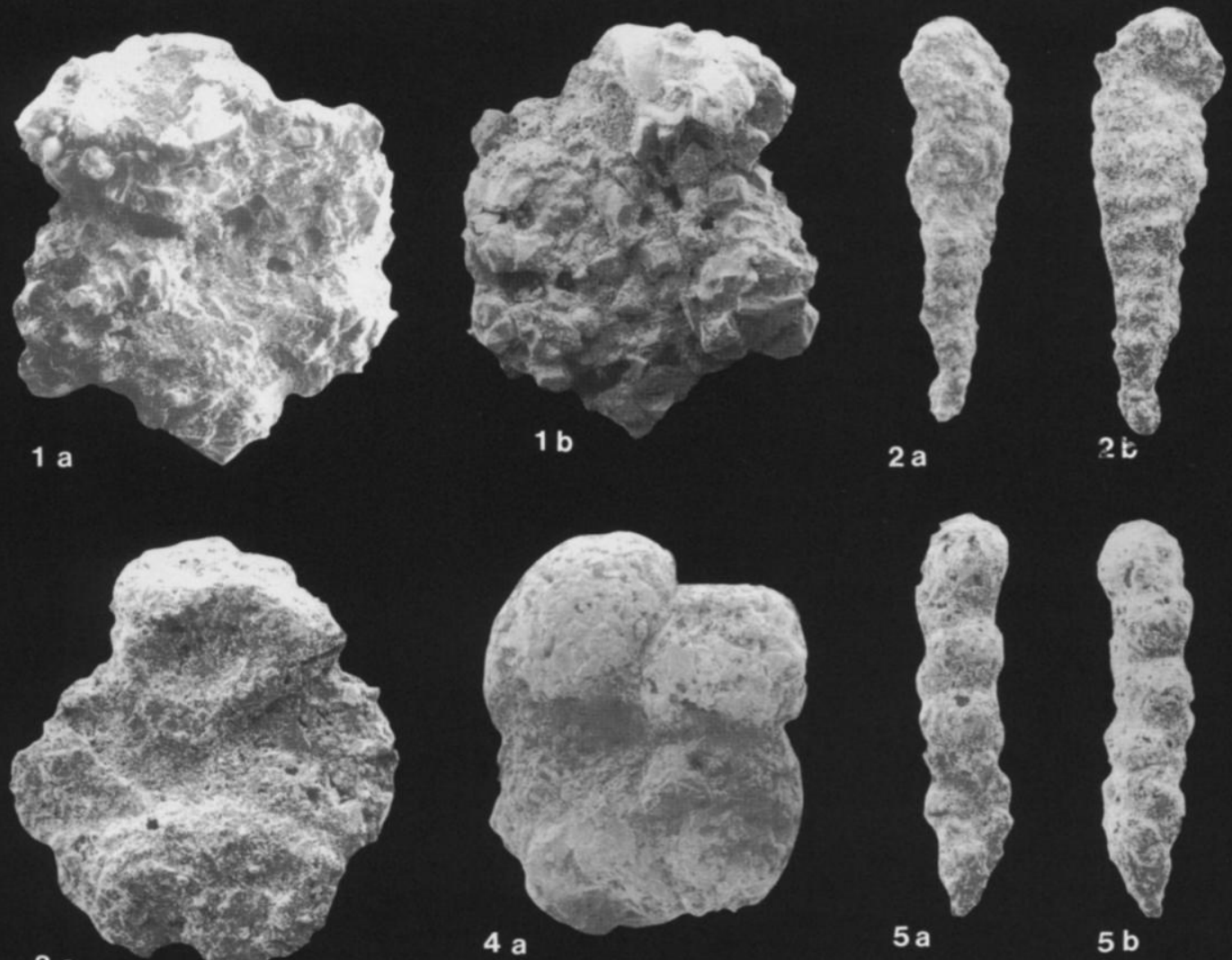

2 a

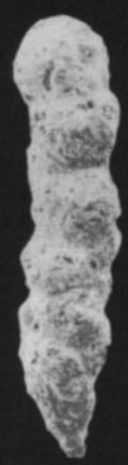

3 a

4 a

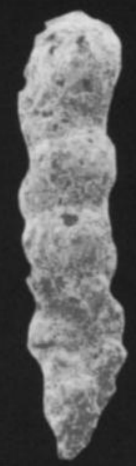

5 a

5 b

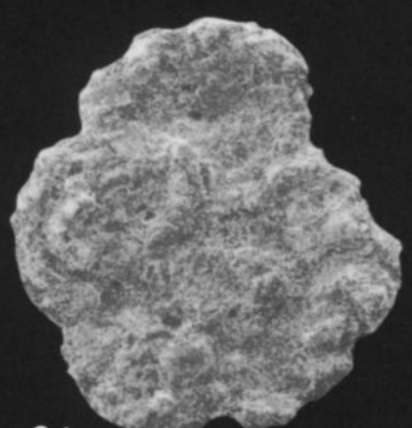

3 b

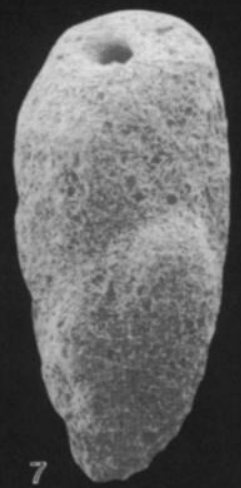

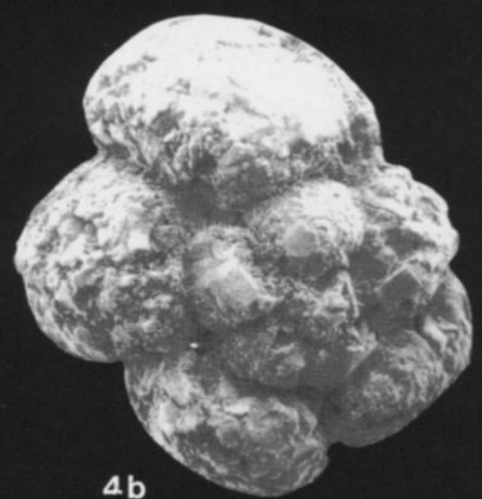

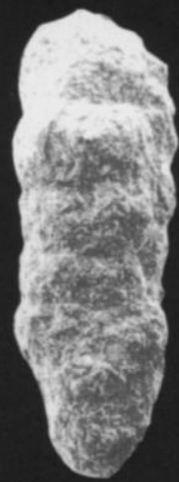

$6 a$

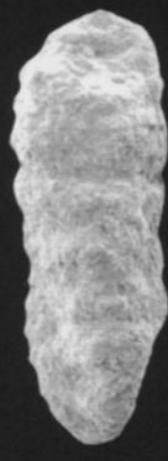

$6 b$
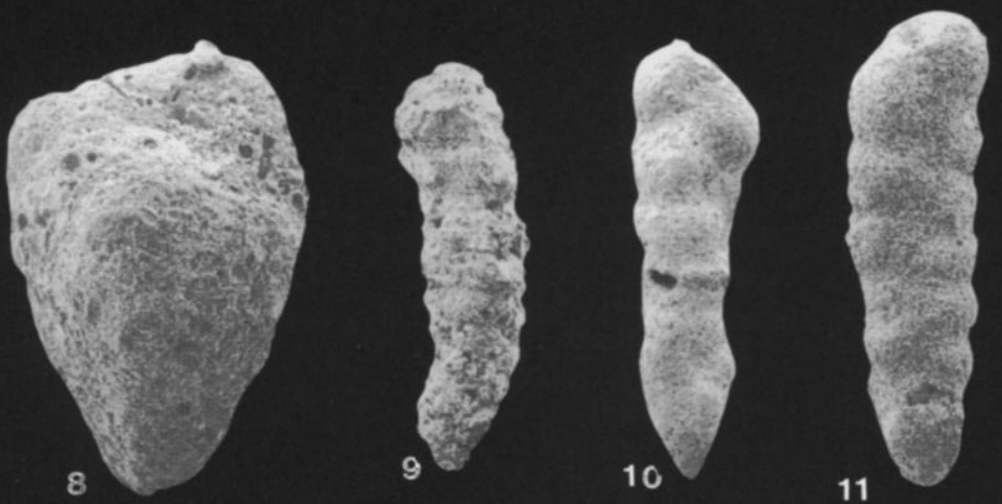
Vaginulinopsis neopachynota Bartenstein and Kaever 1973

Plate 12, figures $4 a-5$

Vaginulinopsis neopachynota BARTENSTEIN and KAEVER 1973, pl. 2, figs. 25-27.

Astacolus neopachynota Bartenstein and Kaever. - BARTENSTEIN 1974a, pl. 2, figs. 22-25.

Description: Elongated, evolute test with planispiral, early portion and prominent, thick, raised sutures. Periphery rounded, aperture terminal at the dorsal margin.

Remarks: Rare at Site 766. Differs from the types by less prominent sutures. Bartenstein (1974a) suggested that V. neopachynota Bartenstein and Kaever is a successor to A. humilis precursoria Bartenstein and Brand, which belongs to the L. nodosa Reuss evolutionary plexus.

Range and Occurrence: A typical Hauterivian species, occuring less frequently in the Barremian (Bartenstein 1974a).

Vaginulinopsis reticulosa Ten Dam 1946

Plate 12, figures $9 \mathrm{a}-12$

Vaginulinopsis reticulosa TEN DAM 1946, pl. 88, fig. 4a, b. - WEIDICH 1990, pl. 22, figs. 1-5.

Marginulinopsis djaffaensis SIGAL 1952, Abb. 9.

Marginulinopsis sigali BARTENSTEIN, BETTENSTAEDT and BOLLI 1957, pl. 5, fig. 99; pl. 6, figs. 130-131.

Description: Test may be planispiral initially or completely evolute. Prominent longitudinal and transverse ribs, often arranged in a patchwork pattern, periphery carinate, convex apertural face with aperture at dorsal margin.

Remarks: This very variable species displays a confusing range of shapes (from involute to evolute) and ornamentation (longitudinal ribs to grid patterns). It has been described under three different names, leading to considerable taxonomic confusion (see also $L$. schreiterei Eichenberg).

Range and Occurrence: Widely recorded in many parts of the world throughout the Early Cretaceous.

\section{Subfamily VAGINULININAE Reuss 1860}

Genus Citharina d'Orbigny 1839

Citharina rudocosta Bartenstein and Brand 1951

Plate 13, figure $1 \mathrm{a}, 1 \mathrm{~b}$

Citharina rudocosta BARTENSTEIN and BRAND 1951, pl. 2, fig. 183; pl. 12A, fig. 340. - NEAGU 1975, pl. 64, figs. 7-12, 14-17 19-21, 23.

Description: Elongated, compressed test with slightly diverging sides, gently pointed, curved proximal end and dorsally elongated last chamber. Four or five raised, longitudinal costae ornament the test.

Range and Occurrence: First described from the mid-Valanginian of northwestern Germany (Bartenstein and Brand 1951). Late Valanginian to late Hauterivian in Rumania (Neagu 1975).

\section{Citharina sp. 1}

Plate 13, figure 2

Description: Flattened, uniserial test with curved dorsal margin and truncate ventral face. Narrow chambers angled at base increasing rapidly in breadth, sutures indistinct. Prominent, raised, bifurcating, sinusoidal costae do not all extend to first and last chambers. Radiate, dorsal aperture.

Remarks: Very rare at Site 766 . Some similarity to the Jurassic species $C$. inaequistriata Terquem 1864.

Genus Planularia Defrance 1826

\section{PLATE 4}

la,b Laevidentalina communis (d'Orbigny), ( $\times 65, \times 65)$, Sample 766A-29R-03; 54-58cm.

2a, b Laevidentalina communis (d'Orbigny), $(\times 45, \times 45)$, Sample 766A-49R-02; 42-46cm.

3ac Laevidentalina communis (d'Orbigny), $(\times 60, \times 60$, $\times 900$ ), Sample 766A-44R-05; 102-106cm.

4a,b Laevidentalina nana (Reuss), ( $\times 95, \times 95)$, Sample 766A-28R-01; 21-25cm.

5a,b Laevidentalina oligostegia (Reuss), $(\times 80, \times 80)$, Sample 766A-32R-02; $104-108 \mathrm{~cm}$.

6a, b Laevidentalina soluta Reuss, $(\times 85, \times 90)$, Sample 766A44R-05; 102-106cm.

7 Laevidentalina sp., ( $\times 95)$, Sample 766A-40R-01; 84$88 \mathrm{~cm}$.
$8 \quad$ Pyramidulina cf. bactriodes (Reuss), $(\times 160)$, Sample 766A-40R-01; 84-88cm.

9 Pyramidulina cf. bactriodes (Reuss), ( $\times 90)$, Sample 766A-33R-02; $15-18 \mathrm{~cm}$.

10 Pyramidulina cf. corallina (Gümbel), $(\times 100)$, Sample 766A-28R-05; 133-138cm.

11 Pyramidulina lagenoides (Wisniowski), $(\times 120)$, Sample 766A-44R-03; $47-52 \mathrm{~cm}$.

12 Nodosaria cf. regularis Terquem, (×85), Sample 766A29R-03; 54-58cm.

13a,b Pyramidulina obscura (Reuss), $(\times 100, \times 100)$, Sample 766A-44R-05; 102-106cm.

14ac Pyramidulina zippei (Reuss), $(\times 70, \times 70)$, Sample 766A-33R-02; $15-18 \mathrm{~cm}$. 

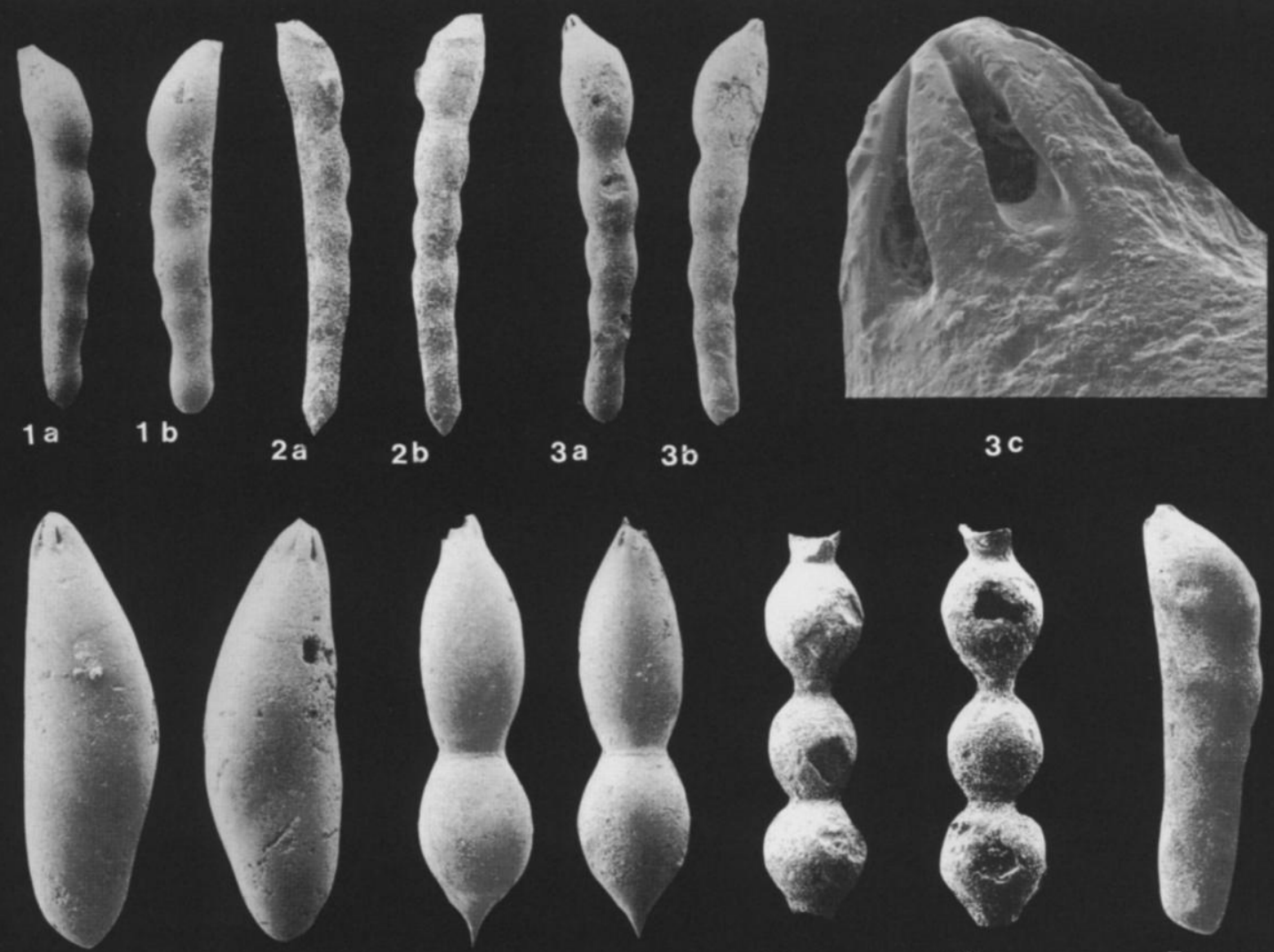

$4 \mathrm{~b}$

5 a

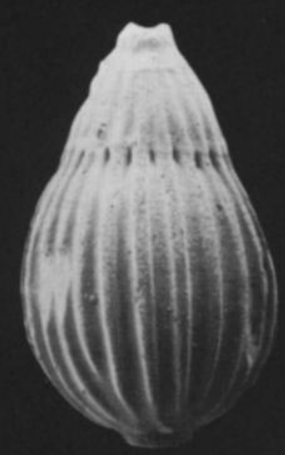

9

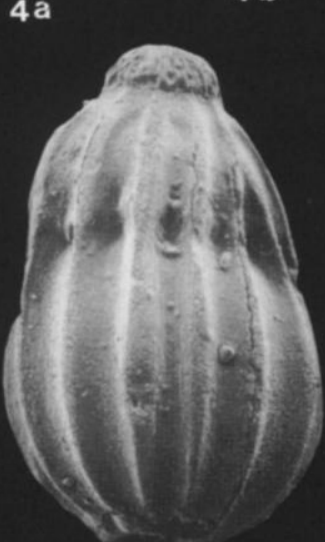

8

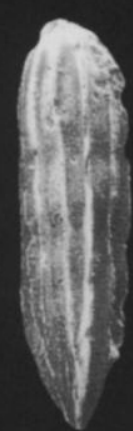

$13 a$

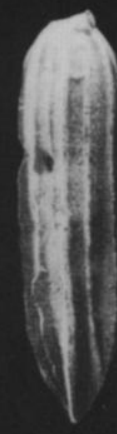

$13 b$
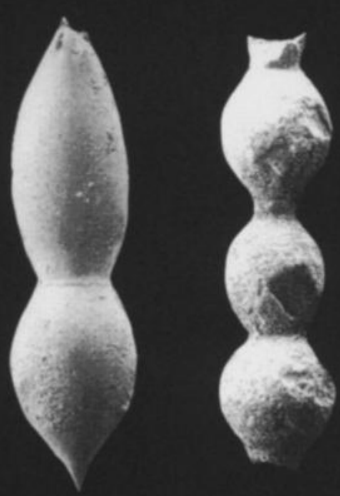

$5 b$
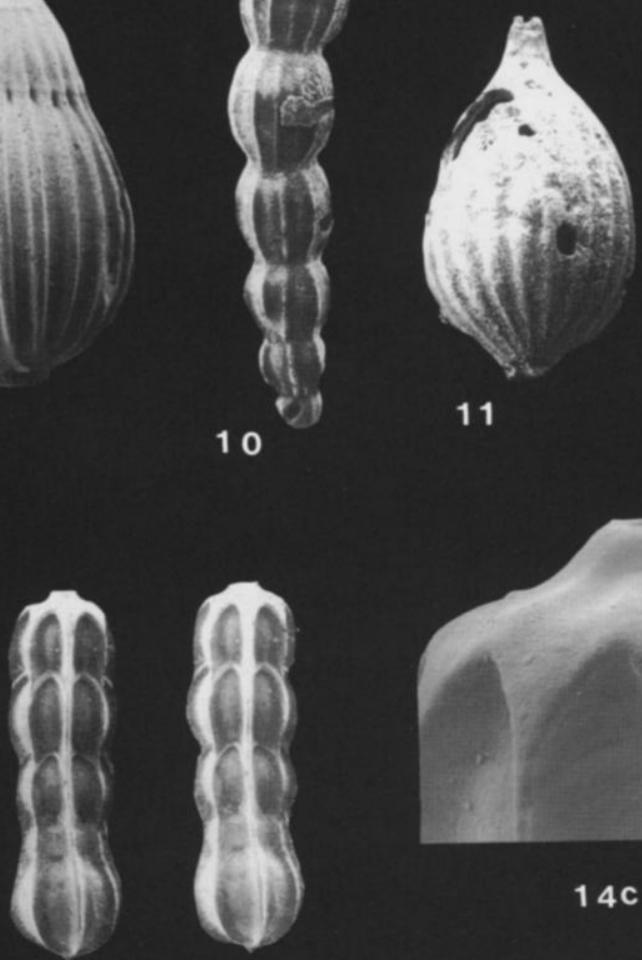

11

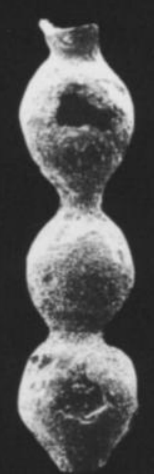

$6 \mathrm{~b}$

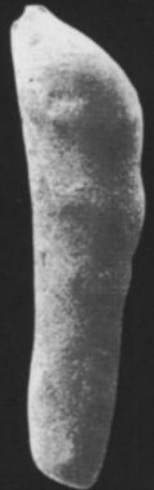

7

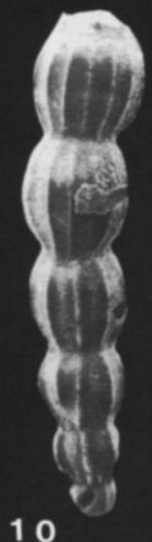

$14 \mathrm{C}$

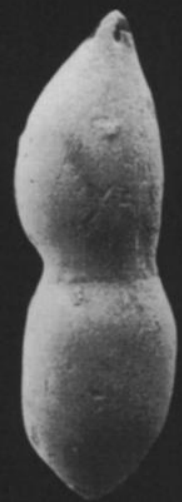

12

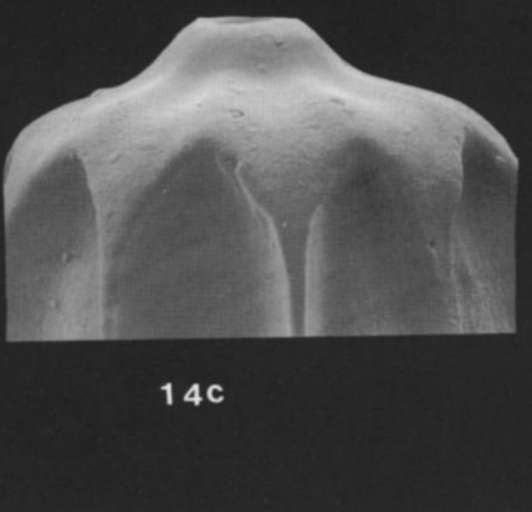


Planularia complanata (Reuss 1845)

Plate 13, figures $4-6 b$

Cristellaria complanata REUSS 1845 , pl. 13, fig. 54a, b.

Planularia madagascariensis ESPITALIÉ and SIGAL 1963, pl. 6, figs. 8-11; pl. 24.

Planularia complanata (Reuss). - WEIDICH 1990, pl. 40, figs. 13-14.

Description: Flattened fan-shaped test with numerous low chambers separated by curved, slightly limbate sutures. Shape of test varies quite considerably from open fan to elongated with sub-parallel sides. Initial spire unevenly developed, faint, short lineations may ornament some tests. Dorsal edge mostly sharp and narrowly carinate, radiate aperture at dorsal angle.

Remarks: Espitalié and Sigal (1963) have suggested that this very variable species may have evolved from one of the many Jurassic forms. Although the ornamentation is lacking or very faint on most tests, the specimens from Site 766 are similar to P. madagascariensis Espitalié and Sigal.

Range and Occurrence: Planularia madagascariensis Espitalié and Sigal ranges from the Callovian to the Valanginian in the Majunga Basin. Planularia complanata Reuss has been recorded in the Hauterivian, Aptian and Albian of the northern Alps (Weidich 1990).

\section{Planularia crepidularis Roemer 1842}

Plate 13, figures $9 \mathrm{a}-10 \mathrm{~b}$

Planularia crepidularis ROEMER 1842, pl. 7B, fig. 4.

Lenticulina crepidularis Roemer. - BARTENSTEIN and BRAND 1951, pl. 5, figs. 106-108. — RIEGRAF 1989, pl. 2, figs. 10-11.

Description: Flattened test with early planispiral stage, becoming evolute. Sutures curved, marked by strong carinae which may not extend to the umbilicus. Dorsal periphery tricarinate, ventral periphery usually carinate. Phyaline, radiate aperture at the dorsal periphery.
Remarks: The tests from Site 766 vary in the degree of coiling, keel development and ornamentation (additional ornamentation may be present in the form of irregular, longitudinal, nodulose ribs). Some authors have divided the taxon into several subspecies to account for various morphological and stratigraphical differences (e.g. Bartenstein, Bettenstaedt and Bolli 1957; Weidich 1990). At Site 766 the morphological variability does not appear stratigraphically correlated. Some very ornamented specimens appear to be transitional forms to L. guttata Ten Dam.

Range and Occurrence: Late Valanginian-early Barremian in northwest Germany (Bartenstein and Brand 1951). Oxfordian-Aptian in the North Atlantic, northern Germany, southern Sweden and the Indian Ocean (Riegraf 1989).

Genus Psilocitharella Loeblich and Tappan 1986

Psilocitharella arguta (Reuss 1860)

Plate 14, figure 6

Vaginulina arguta REUSS 1860, pl. 8, fig. 4.

Vaginulina arguta Reuss. - BARTENSTEIN and KAEVER 1973, pl. 4, figs. 55-56. - NEAGU 1975, pl. 65, figs. 3, 12, pl. 66, figs. 1-2, 7, 12, 16 ; pl. 67 , fig. 3.

Description: Elongated, narrow test with slightly diverging sides. First chamber markedly inflated and last chamber elongated towards terminal, radiate aperture. Sharp, lateral carinae, inclined raised sutures.

Remarks: This species is quite variable. The specimen illustrated on pl. 14 , fig. 6 , is slightly arched, triangular in cross-section and has few chambers; it is probably a juvenile as described by Neagu (1975).

Range and Occurrence: Hauterivian-Barremian in Rumania (Neagu 1975).

\section{PLATE 5}

1 Pyramidulina sp., (×70), Sample 766A-34R-02; 30$33 \mathrm{~cm}$.

2 Pyramidulina sp., (×60), Sample 766A-40R-02; 46$50 \mathrm{~cm}$.

3a,b Pseudonodosaria humilis (Roemer), $(\times 120, \times 120)$, Sample 766A-45R-02; 109-113cm.

4a,b Pseudonodosaria mutabilis (Reuss), $(\times 70, \times 70)$, Sample 766A-44R-05; 102-106cm.

5a,b Lingulina sp., $(\times 130, \times 130)$, Sample 766A-30R-03; $100-102 \mathrm{~cm}$.

6 Lingulina sp., $(\times 85)$, Sample 766A-28R-03; 116-120cm.

$7 \quad$ Lingulina sp. 1, $(\times 130)$, Sample 766A-28R-05; 133$138 \mathrm{~cm}$. 8a,b Lingulina sp. $1,(\times 165, \times 160)$, Sample 766A-28R-05; $133-138 \mathrm{~cm}$.

9 Frondicularia sp. (juvenile), $(\times 130)$, Sample 766A$38 \mathrm{R}-01 ; 112-116 \mathrm{~cm}$

10a,b Frondicularia hastata Roemer, $(\times 40, \times 40)$, Sample 766A-47R-01; 98-103cm.

11 Frondicularia hastata Roemer, $(\times 40)$, Sample 766A49R-01; 124-128cm.

12a,b Frondicularia hastata Roemer, $(\times 32, \times 32)$, Sample 766A-47R-01; 98-103cm.

13 Frondicularia bettenstaedti Zedler, $(\times 60)$, Sample 766A-40R-01; 84-88cm. 


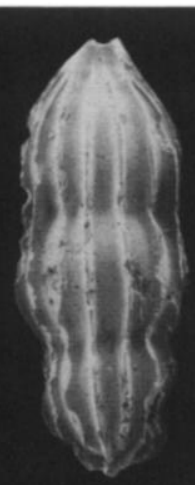

1
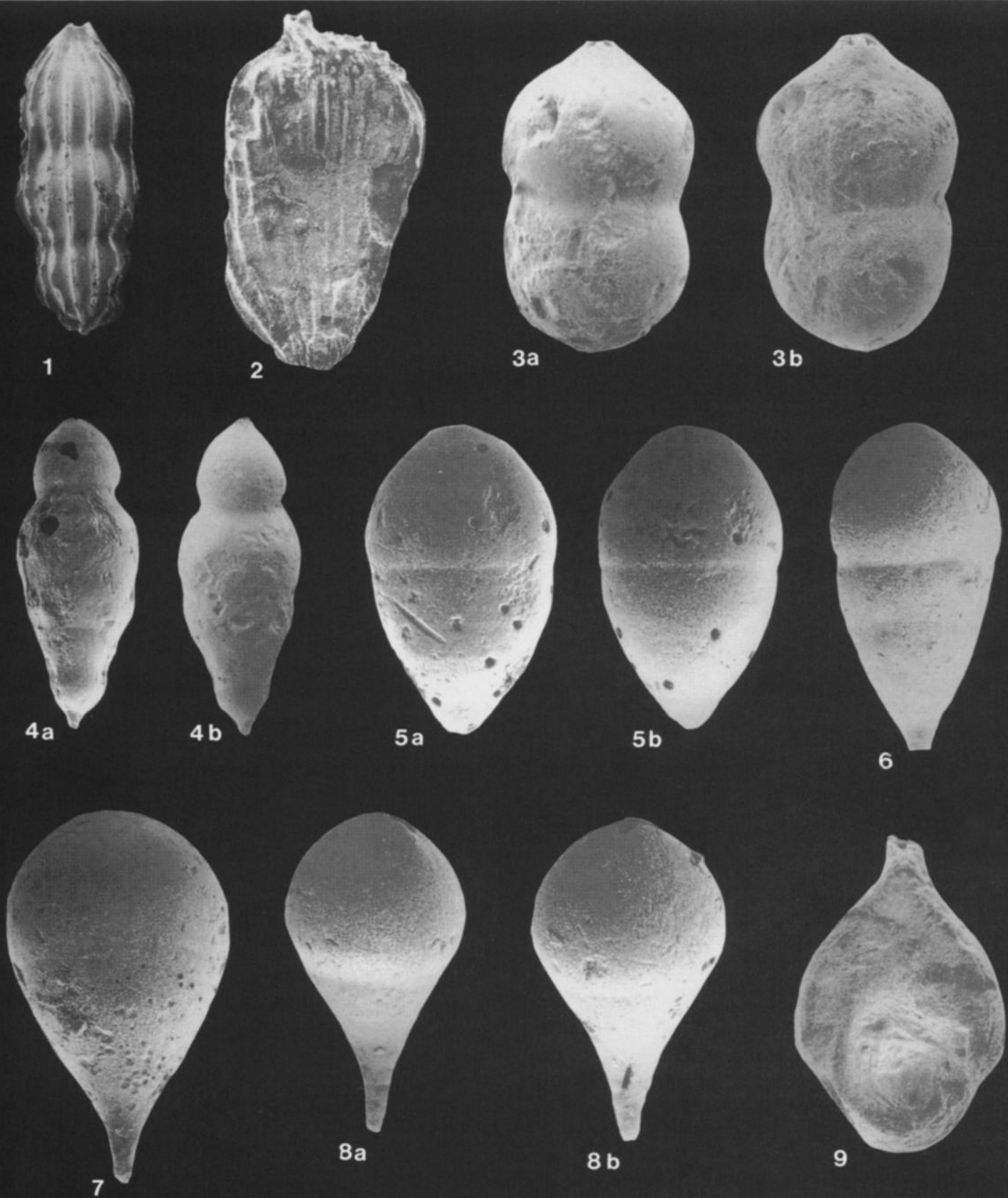

$8 \mathbf{a}$
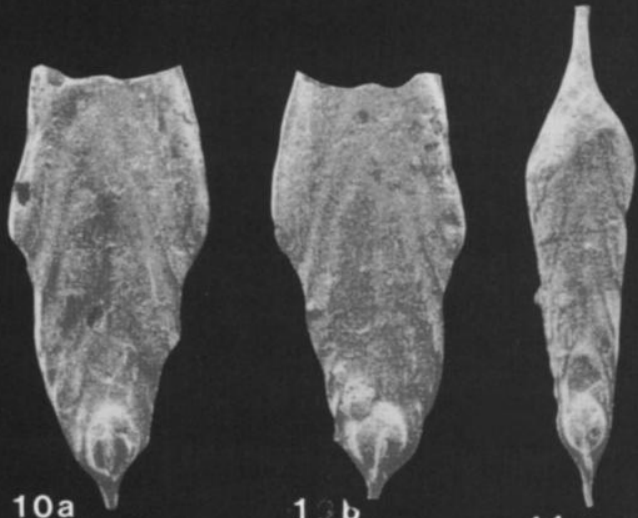

11

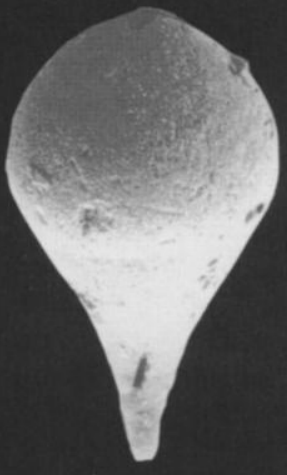

8 b

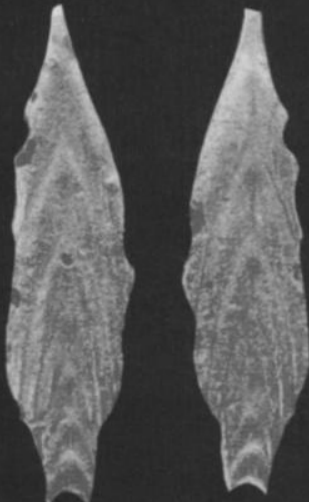

$12 b$

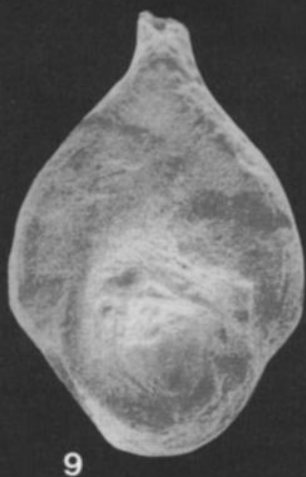

$12 \mathrm{a}$

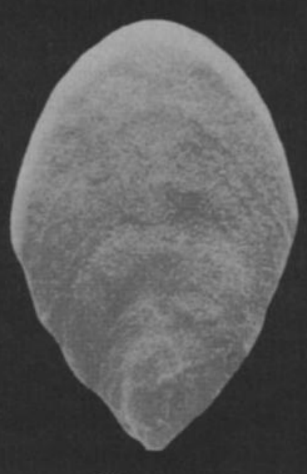

13 
Psilocitharella kochii (Roemer 1841)

Plate 14, figure $3 \mathrm{a}, 3 \mathrm{~b}$

Vaginulina kochii ROEMER 1841, pl. 15, fig. 10. - BARTENSTEIN and BRAND 1951, pl. 6, figs. 158-159. - WEIDICH 1990, Abb. 21/2-3.

Description: Compressed, harp-shaped test with strongly diverging sides. Last chamber tapers towards radiate, terminal, dorsal aperture, sutures indistinct.

Range and Occurrence: Index marker for the late Valanginian in northwestern Germany, less frequently in the Hauterivian-Aptian (Bartenstein and Brand 1951). Valanginian to Albian in Tethyan and transitional boreal facies of the northern hemisphere (Bartenstein 1977).

Psilocitharella recta (Reuss 1863)

Vaginulina recta REUSS 1863, pl. 2, figs. 14-15. - BARTENSTEIN, BETTENSTAEDT and BOLLI 1957, pl. 5, fig. 103.

Citharina recta (Reuss). - HAIG 1982, pl. 6, figs. 31-34.

Description: Elongated, narrow test with near parallel carinated sides and raised sutures.

Remarks: Only fragments recovered.

Range and Occurrence: Late early Albian-late Albian in Queensland (Haig 1982). Valanginian-Albian of Texas, England, southern France, northern Germany, western Indian Ocean and Central Pacific (Riegraf 1989).

Genus Vaginulina d'Orbigny 1826

Vaginulina petila (Eicher and Worstell 1970)

Plate 14, figure 5a, $5 b$

Citharina petila EICHER and WORSTELL 1970, pl. 2, figs. 20-21. HAIG 1982, pl. 6, figs. 7-10.

Vaginulina sp. 3 BARTENSTEIN and BRAND 1951, pl. 6, fig. 153.

Lenticulina sp. LAMBERT and SCHEIBNEROVÁ 1974, pl. 1, fig. 3.
Description: Elongated, compressed test with sharp dorsal edge and rounded ventral side. Seven low chambers, slightly inflated ventrally, are separated by strongly inclined, depressed sutures. Last chamber becomes very elongated towards the terminal, radiate aperture on the dorsal side. Test is ornamented by several fine, slanting, prominent costae which do not extend over the whole test.

Remarks: Very rare. Virtually identical to $C$. petila Eicher and Worstell illustrated by Haig (1982). More slender than the specimen illustrated by Eicher and Worstell (1970). Differs from Vaginulina sp. 3 illustrated by Bartenstein and Brand (1951) by its narrower test and more elongated last chamber.

Range and Occurrence: First described from the CenomanianTuronian of the Western Interior, U.S.A (Eicher and Worstell 1970), this species has been recorded from the Albian of Queensland (Haig 1982) the Albian of South Africa (Lambert and Scheibnerová 1974), and possibly the Albian of France (Haig 1982). Bartenstein and Brand (1951) described Vaginulina sp. 3 from upper Valanginian sediments in northwestern Germany.

Genus Brunsvigella Meyn and Vespermann 1994

Brunsvigella thoerensis (Bartenstein and Brand 1951)

Plate 14, figures 1, 2a, 2b, 4a, 4b

Vaginulina thoerensis BARTENSTEIN and BRAND 1951, pl. 7, fig. 170 - NEAGU 1975, pl. 64, figs. 27, 30-31.

Citharina thoerensis (Bartenstein and Brand). - HAIG 1982, pl. 6, figs. 3-6.

Description: Elongated, narrow test, tricarinate on dorsal side and sharply edged with two or three prominent, longitudinal costae on the ventral side. The chambers are slightly inflated ventrally and separated by weakly depressed, inclined sutures. In cross-section the test is roughly rhomboidal. Proloculus is small, inflated, with a median rib and a basal spine.

Remarks: Very similar to the forms illustrated by Neagu (1975). Differs from specimens figured by Bartenstein and Brand (1951) by its smaller, rounded proloculus.

PLATE 6

1a,b Frondicularia bettenstaedti Zedler, $(\times 110, \times 115)$, Sample 766 A-33R-02; $15-18 \mathrm{~cm}$.

2a,b Tristix acutangula (Reuss), $(\times 150, \times 150)$, Sample 766A-43R-02; 46-50cm.

3a,b Tristix excavata (Reuss), $(\times 120, \times 120)$, Sample 766A40R-01; 84-88cm.

4 Lenticulina circumcidanea (Berthelin), $(\times 100)$, Sample 766A-30R-04; 100-102cm.

5a,b Lenticulina heiermanni Bettenstaedt, $(\times 40, \times 40)$, Sample 766A-45R-02; 109-113cm.

6 Lenticulina heiermanni Bettenstaedt, $(\times 40)$, Sample 766A-46R-04; 105-110cm.
7 Lenticulina heiermanni Bettenstaedt, $(\times 40)$, Sample 766A-46R-04; 105-110cm.

8a,b Lenticulina heiermanni Bettenstaedt, $(\times 80, \times 85)$, Sample 766A-45R-04; $115-120 \mathrm{~cm}$.

$9 \quad$ Lenticulina macrodisca (Reuss), $(\times 50)$, Sample 766A29R-03; 54-58cm.

10a,b Lenticulina macrodisca (Reuss), $(\times 90, \times 90)$, Sample 766A-30R-03; 100-102cm.

11a,b Lenticulina muensteri (Roemer), $(\times 60, \times 60)$, Sample 766A-47R-04; 114-119cm. 

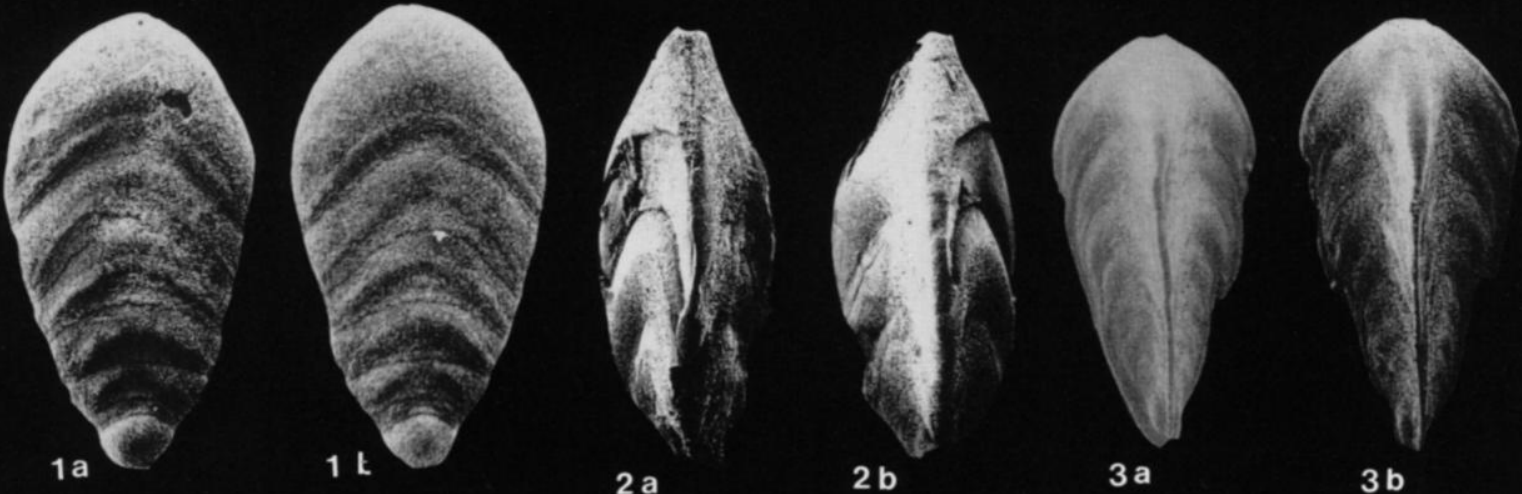

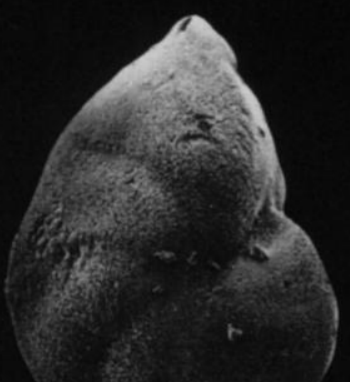

4

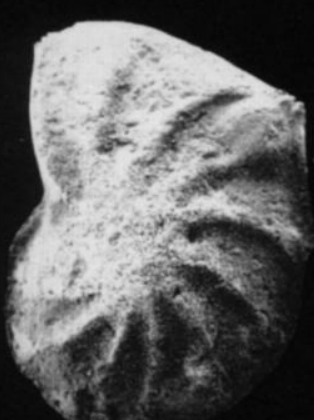

7

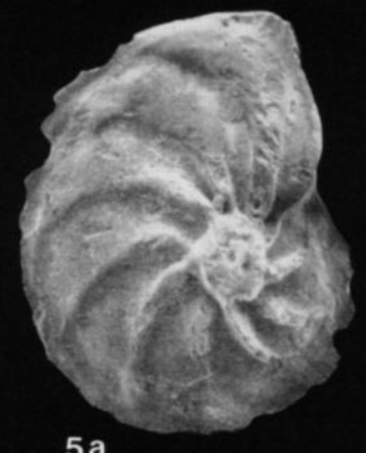

5 a
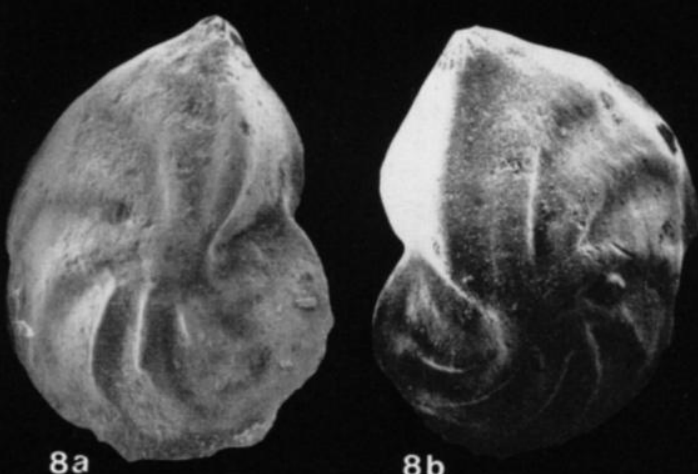

$8 b$

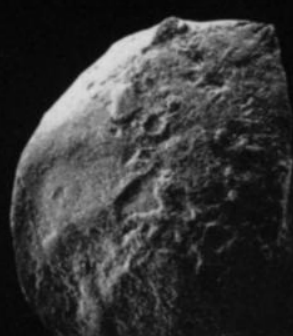

$11 \mathrm{a}$

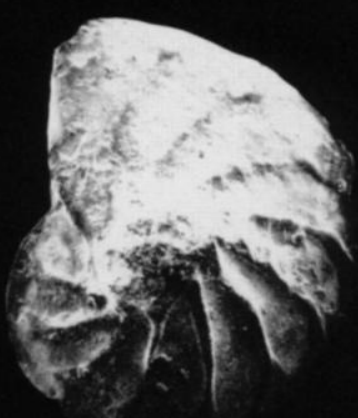

6
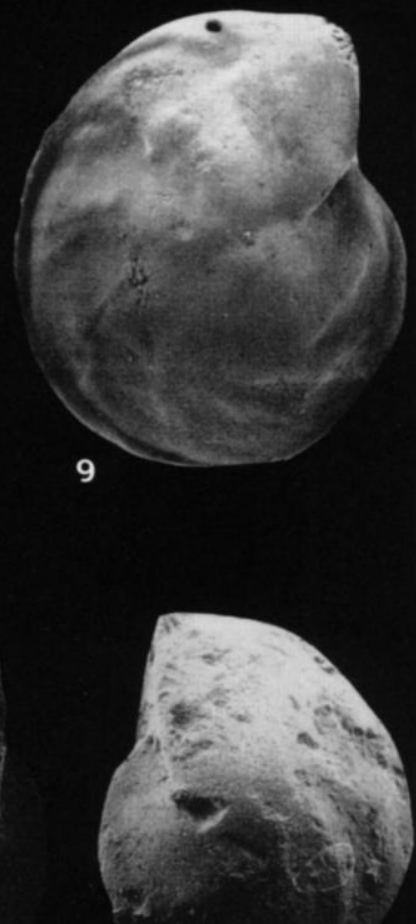

$11 \mathrm{~b}$ 
Range and Occurrence: A cosmopolitan index species for the upper Valanginian (Bartenstein and Brand 1951) and upper Hauterivian in Rumania (Neagu 1975). Recorded from the Albian of Queensland (Haig 1982).

Family POLYMORPHINIDAE d' Orbigny 1839

Subfamily POLYMORPHININAE d' Orbigny 1839

Genus Eoguttulina Cushman and Osawa 1930

Eoguttulina ichnusae (Dieni and Massari 1966)

Plate 16, figure $1 \mathrm{a}, 1 \mathrm{~b}$

Guttulina ichnusae DIENI and MASSARI 1966, pl. 6, figs. 29-31. NEAGU 1975, pl. 76, figs. 27-30; pl. 108, figs. 28-30.

Description: Slightly compressed, ovate test with elongate chambers added spirally in planes less than $90^{\circ}$ apart. Depressed, oblique sutures and fine costate ornamentation.

Remarks: Very rare. Ornamentation most similar to that illustrated by Dieni and Massari (1966),

Range and Occurrence: Upper Valanginian in Sardinia (Dieni and Massari 1966). Upper Hauterivian, Barremian and lower Aptian in Rumania (Neagu 1975).

Genus Globulina d' Orbigny 1839

Globulina bucculenta (Berthelin 1880)

Plate 15 , figure $6 a, 6 b$

Polymorphina bucculenta BERTHELIN 1880, pl. 4, figs. 17-20. Globulina bucculenta (Berthelin). - RIEGRAF 1989, pl. 2, figs. 17-20.

Description: Moderately inflated test, pointed at the proximal end with three strongly overlapping chambers arranged along three planes. Sutures depressed and radiating, terminal aperture large and straight.

Remarks: Identical to specimens from ODP Site 249 illustrated by Riegraf (1989) in pl. 2, figs. 17-20.
Range and Occurrence: North Atlantic, eastern Indian Ocean and Central Pacific in Valanginian-Albian sediments (Riegraf 1989).

Globulina lacrima (Reuss 1845)

Plate 15 , figures $4 a-5 b$

Polymorphina lacrima REUSS 1845, pl. 12, fig. 6a-c. Globulina lacrima (Reuss). - WEIDICH 1990, pl. 26, figs. 25-26.

Globulina cf. lacrima (Reuss). - FOWLER and BRAUN 1993, pl. 9, figs. 4-5.

Description: Ovate test with rounded base and slightly tapering apertural end. Few rapidly increasing chambers separated by flush indistinct sutures. Aperture large, radiate.

Range and Occurrence: Albian to Late Cretaceous in the northern Alps (Weidich 1990). Cretaceous in Europe and Gulf Cost of USA (Fowler and Braun 1993).

Globulina prisca (Reuss 1863)

Plate 15, figures $7 \mathrm{a}-9$

Polymorphina prisca REUSS 1863, pl. 8, fig. 8.

Globulina prisca (Reuss). - BARTENSTEIN and BRAND 1951, pl. 10, fig. 286. - FOWLER and BRAUN 1993, pl. 9, figs. 8-10.

Description: Elongated test, moderately inflated and slightly pointed at the proximal end with three overlapping chambers arranged along three planes. Sutures slightly depressed and terminal, radiate aperture.

Range and Occurrence: A cosmopolitan species in the Early Cretaceous recorded in Germany, Netherlands, England, Poland, Alaska, France, Norway (Fowler and Braun 1993).

Genus Palaeopolymorphina Cushman and Ozawa 1930

Palaeopolymorphina sp. 1

Plate 16, figures 13-15b

Description: Elongated test, broadly rounded at the base and narrower at the top. Five or more overlapping chambers initially
$1 \quad$ Lenticulina muensteri (Roemer), ( $\times 75)$, Sample 766A45R-02; 109-113cm.

2a,b Lenticulina nodosa (Reuss), $(\times 160, \times 160)$, Sample 766A-46R-05; 20-24cm

3 Lenticulina saxocretacea Bartenstein, $(\times 120)$, Sample 766A-32R-02; 104-108cm.

4a,b Lenticulina pulchella (Reuss), $(\times 140, \times 140)$, Sample 766A-33R-02; $15-18 \mathrm{~cm}$.

5a,b Lenticulina pulchella (Reuss), $(\times 190, \times 190)$, Sample 766A-30R-03; 100-102cm.

6 Lenticulina sp. (transitional), $(\times 120)$, Sample 766A30R-04; 100-102cm.
$7 \quad$ Lenticulina sp. (transitional), (×90), Sample 766A-45R$02 ; 109-113 \mathrm{~cm}$

$8 \quad$ Lenticulina sp. (transitional), ( $\times 75)$, Sample 766A-45R$02 ; 109-113 \mathrm{~cm}$.

$9 \quad$ Lenticulina sp. (transitional), ( $\times 75)$, Sample 766A-45R$04 ; 115-120 \mathrm{~cm}$.

10 Lenticulina ouachensis (Sigal), $(\times 80)$, Sample 766A43R-05; 131-135cm.

11a,b Lenticulina ouachensis (Sigal), $(\times 105, \times 100)$, Sample 766A-47R-01; 98-103cm.

12 Lenticulina ouachensis (Sigal), ( $\times 95)$, Sample 766A47R-03; 25-30cm. 


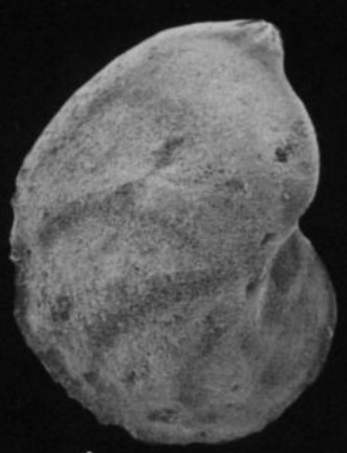

1

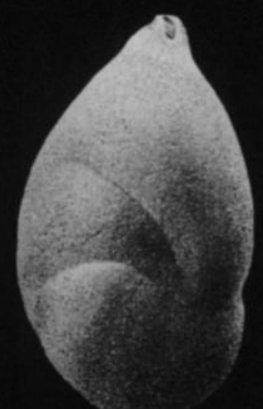

$4 a$

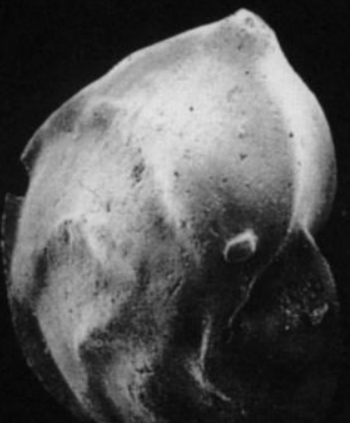

6

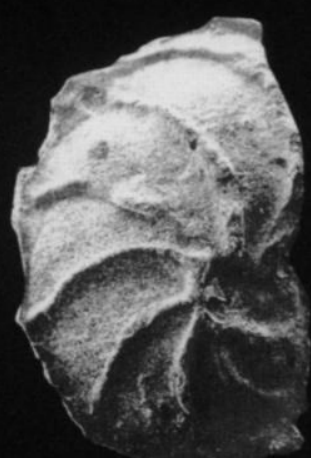

10
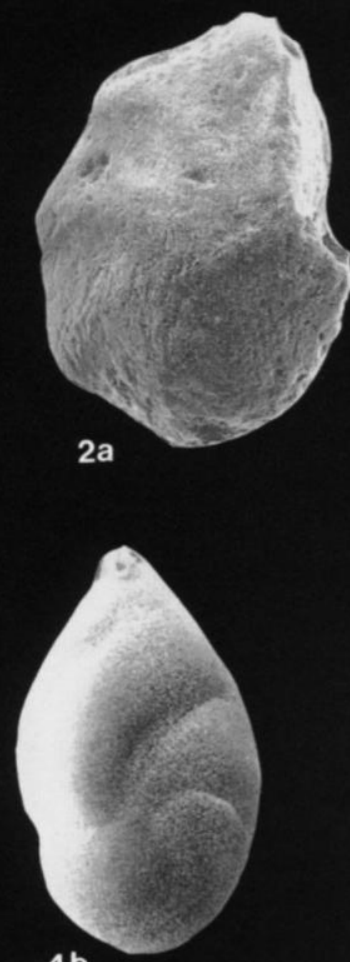

$4 b$

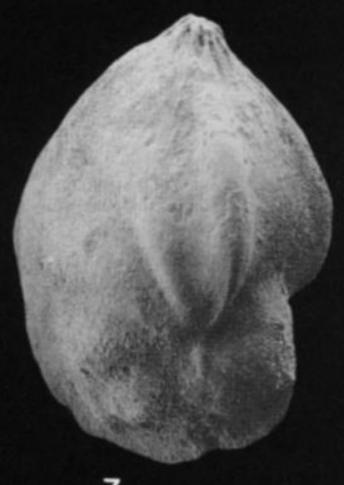

7

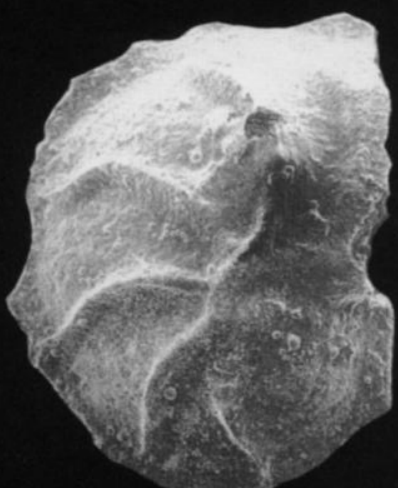

11 a
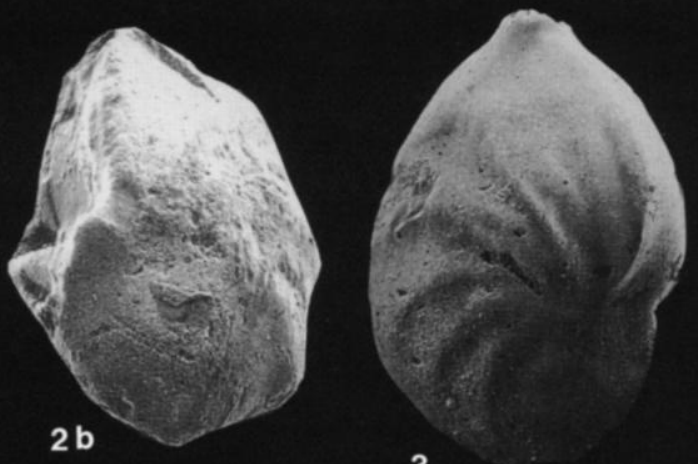

3

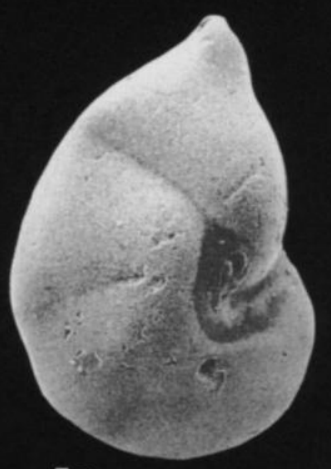

5 a
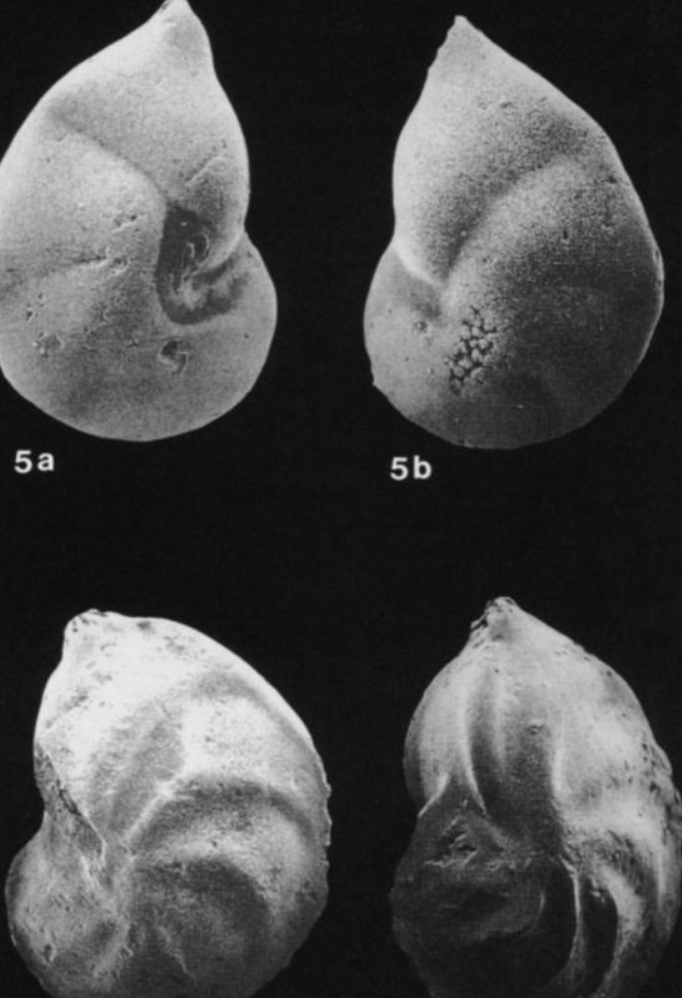

8

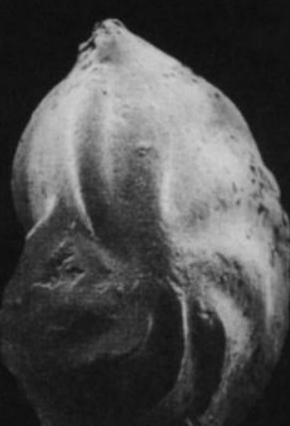

9

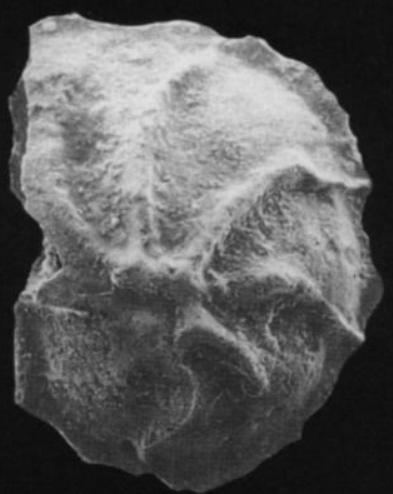

$11 \mathrm{~b}$

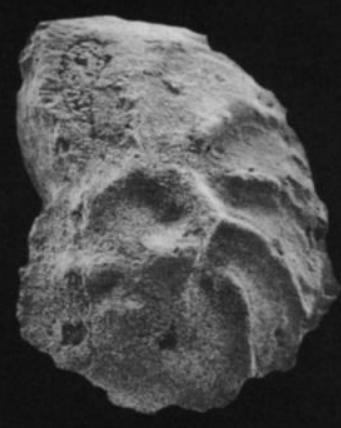

12 
biserial, then tending to become uniserial. Early chambers small, increasing rapidly in size. Sutures oblique, faintly depressed in early portion, becoming distinctly depressed between younger chambers. In well-preserved specimens the surface of the test appears rough and a distinct spine is present at the base of the first chamber. The last chamber tapers towards a phialine, radiate aperture at the end of a short neck.

Remarks: Tests are variable in shape: some are squat with broad chambers, others more slender and only loosely biserial. This species closely resembles Palaeopolymorphina inflata Espitalié and Sigal (1963 pl. 30, fig. 18) and ?Glandulina aptiensis Myatlyuk and Vasilenko 1988 (pl. 57, figs. 1-9) although the specimen illustrated by Espitalié and Sigal is more globular, without basal extension and with a smaller, indistinct aperture while the specimens described by Myatlyuk and Vasilenko have simpler aperture and no basal extension. Neagu (pers. comm. 1993) suggests that these forms are polymorphinid gamonts.

Range and Occurrence: Espitalié and Sigal (1963) use $P$. inflata Espitalié and Sigal as a zonal marker for the base of the late Valanginian in the Majunga Basin.

Genus Pyrulina d' Orbigny 1839

Pyrulina cylindroides (Roemer 1838)

Plate 15, figure 10

Polymorphina cylindroides ROEMER 1838, pl. 3, fig. 26a, b.

Pyrulina cylindroides (Roemer). - McNEIL and CALDWELL 1981, pl.

17, fig. 16. - RIEGRAF and LUTERBACHER 1989a, pl. 4, figs. 23-24.

Description: Test fusiform, subcircular in cross-section, tapering slightly at both extremities. Overlapping chambers are added spirally and separated by flush sutures. Large radiate, terminal aperture.
Range and Occurrence: A cosmopolitan species recorded from the Cretaceous to Recent (Riegraf and Luterbacher 1989a).

Subfamily RAMULININAE Brady 1884

Genus Ramulina T.R. Jones 1875

Ramulina aptiensis Bartenstein and Brand 1951

Plate 16, figure 8

Ramulina aptiensis BARTENSTEIN and BRAND 1951, pl. 11, fig. 332.

Description: Elongated, irregular chambers connected by stolons. Surface ornamented with short, thick spines.

Range and Occurrence: Rare in the Valanginian to Aptian of northwestern Germany but becoming common in the Aptian and Albian (Bartenstein and Brand 1951).

Ramulina tappanae Bartenstein and Brand 1951 Plate 16, figures 9-11

Ramulina tappanae BARTENSTEIN and BRAND 1951, pl. 11, figs. 305307. - RIEGRAF 1989, pl. 2, figs. 21-22.

Description: Subglobular or irregular chambers joined by stolons. Surface finely or coarsely spinose, aperture at the end of open stolons.

Remarks: Included in this species are tubular, branching fragments which may represent original connecting stolons.

Range and Occurrence: Cosmopolitan from the Valanginian to the the Albian (Riegraf 1989).

Family ELLIPSOLAGENIDAE A. Silvestri 1923

Subfamily OOLININAE Loeblich and Tappan 1961

Genus Oolina d'Orbigny 1839

Oolina caudata d'Orbigny 1840

Plate 16, figure 5

\section{PLATE 8}

la,b Lenticulina subangulata (Reuss), $(\times 50, \times 50)$, Sample 766A-39R-03; 86-90cm.

2a,b Lenticulina sp., $(\times 90, \times 100)$, Sample 766A-44R-03; 47$52 \mathrm{~cm}$.

3 Lenticulina sp., $(\times 150)$, Sample 766A-32R-02; 104$108 \mathrm{~cm}$.

4a,b Lenticulina cf. subgaultina Bartenstein, $(\times 60, \times 60)$, Sample 766A-49R-01; 124-128cm.

5a,b Marginulinopsis comma (Roemer), $(\times 85, \times 90)$, Sample 766A-45R-02; 109-113cm.

6a,b Saracenaria compacta Espitalié and Sigal, $(\times 120$, $\times 120$ ), Sample 766A-47R-03; 27-30cm.

7 Marginulinopsis bettenstaedti Bartenstein and Brand, (×150), Sample 766A-47R-03; 27-30cm.
8 Marginulinopsis bettenstaedti Bartenstein and Brand, (×130), Sample 766A-29R-03; 54-58cm.

9 Marginulinopsis bettenstaedti Bartenstein and Brand, (×140), Sample 766A-49R-01; 124-128cm.

10a,b Saracenaria compacta Espitalié and Sigal, $(\times 45, \times 45)$, Sample 766A-29R-03; 54-58cm.

11 Marginulinopsis gracilissima (Reuss), $(\times 105)$, Sample 766A-38R-03; 111-113cm.

12 Marginulinopsis gracilissima (Reuss), $(\times 140)$, Sample 766A-47R-03; 25-30cm.

13 Marginulinopsis gracilissima (Reuss), $(\times 115)$, Sample 766A-38R-03; 111-113cm. 


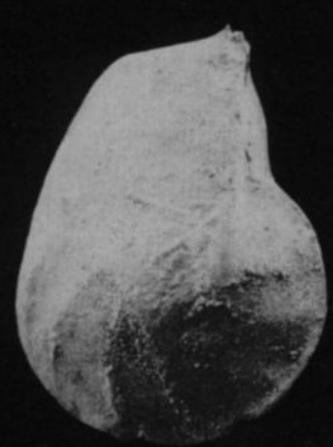

1 a

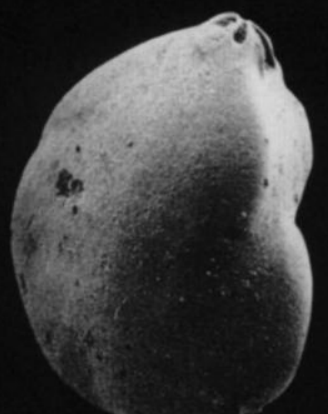

3

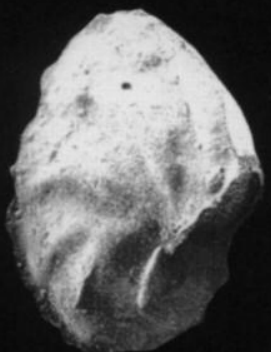

$6 a$

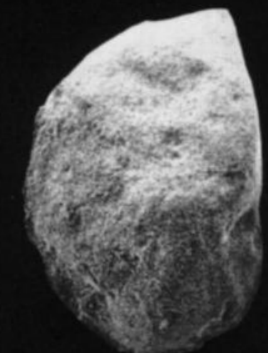

4 a

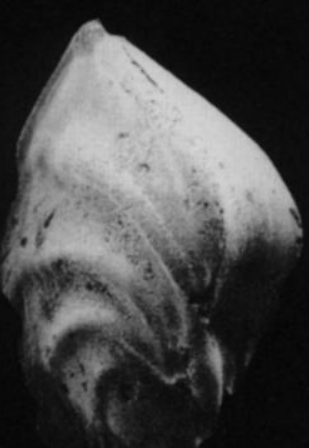

$10 a$

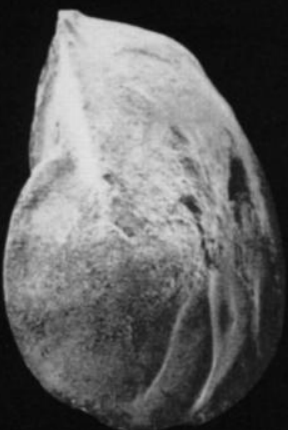

1 b

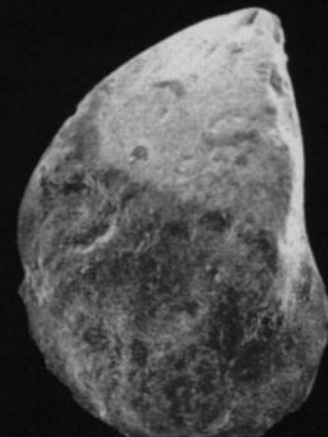

2 a

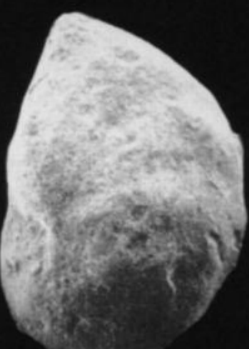

4 b

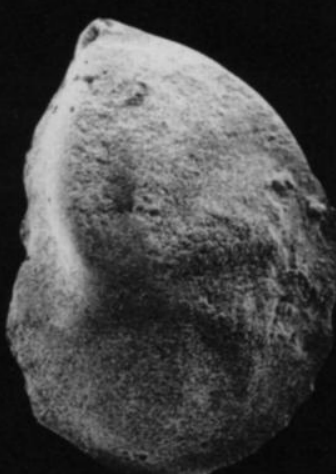

2 b

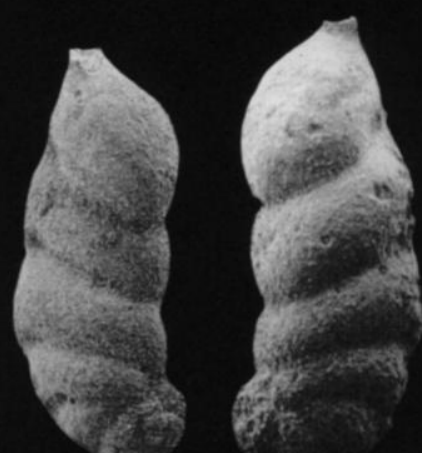

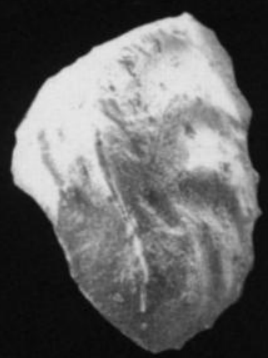

$6 b$
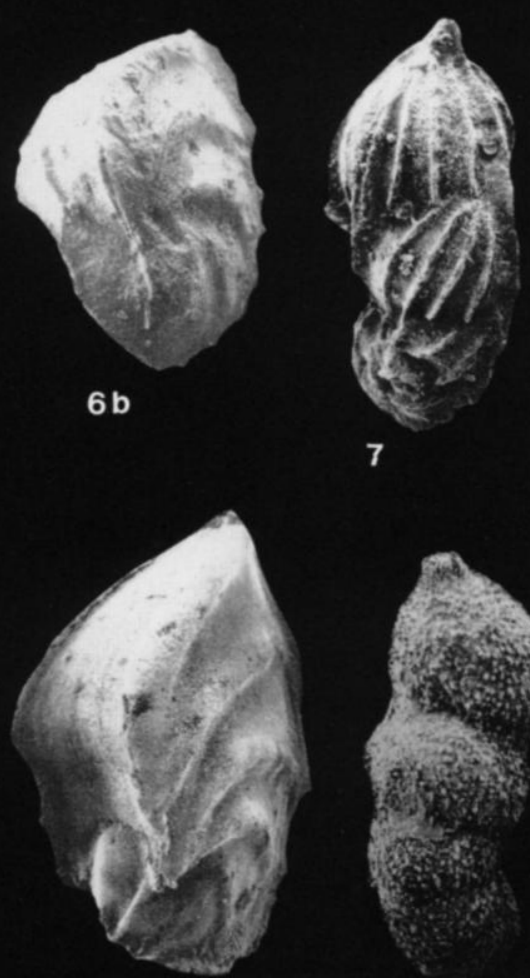

$10 b$
7

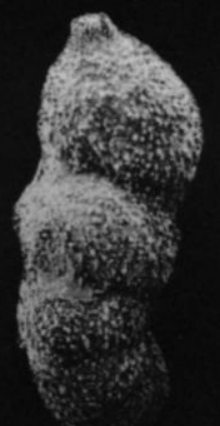

11
5 a

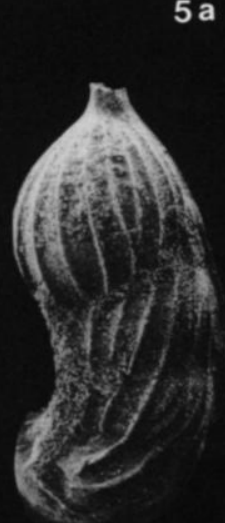

8

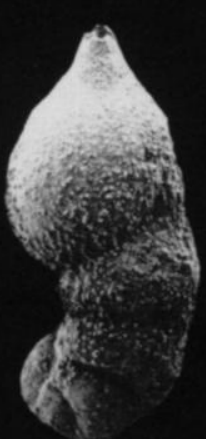

12

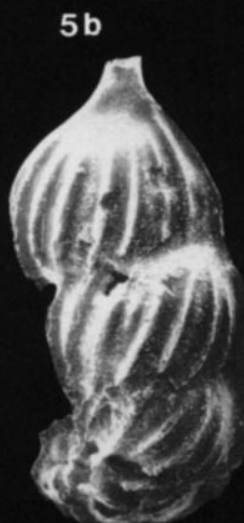

9

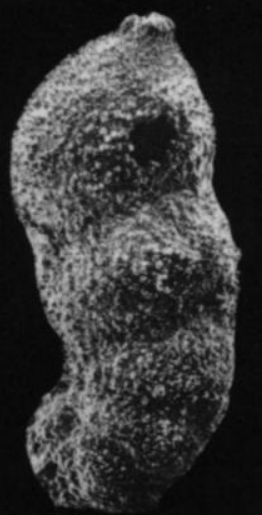

13 
Oolina caudata d'ORBIGNY 1840, pl. 5, fig. 6.

Lagena cf. caudata (d'Orbigny). - BARTENSTEIN and BRAND 1951, pl. 10, fig. 282; pl. 13, fig. 352 .

Description: Unilocular, pear shaped test with a rounded aperture at the end of a thick tapering neck. Ten thick, longitudinal costae ornament all but the top of the test.

Remarks: Only one specimen found at Site 766.

Range and Occurrence: Recorded by Bartenstein and Brand (1951) from middle and upper Valanginian deposits of northwestern Germany.

Oolina hauteriviana cylindracea (Bartenstein and Brand 1951)

Lagena hauteriviana cylindracea BARTENSTEIN and BRAND 1951, pl. 10, figs. 279-280. - WEIDICH 1990, pl. 45, figs. 11-12.

Description: Unilocular, cylindrical test, tapering at both ends. Rounded aperture at the end of a short neck.

Remarks: Very rare at Site 766.

Range and Occurrence: Bartenstein and Brand (1951) use $O$. hauteriviana cylindracea as an index species for the lower Hauterivian in northwestern Germany. Also recorded by Weidich (1990) in the Berriasian of the northern Alps where its rare occurrence and different range from Germany suggest distinct Tethyan and boreal distributions.

Oolina laevis (Montagu 1803)

Plate 16, figure 4

Vermiculum laeve MONTAGU 1803; Test. Brit., S. 524.

Lagena laevis (Montagu). - BARTENSTEIN and BRAND 1951, pl. 10, fig. 274. - NEAGU 1975, pl. 69, figs. 20, 21, 24.

Description: Unilocular, globular test with rounded aperture on short neck and smooth surface.

Remarks: Shape varies from cylindrical to slightly elongate.
Range and Occurrence: Recorded in the Valanginian of northwestern Germany by Bartenstein and Brand (1951), by Neagu (1975) in the Hauterivian and Barremian of Rumania.

Oolina aff. oxystoma (Reuss 1858)

Plate 16, figure 6

Lagena oxystoma REUSS 1858, pl. 5, fig. 66.

Oolina aff. oxystoma (Reuss). - BARTENSTEIN and BRAND 1951, pl. 10, fig. 33; pl. 13, figs. 354-356. - BARTENSTEIN and BOLLI 1986, pl. 4, figs. 4-6.

Description: Subglobular test, finely to coarsely spinose with rounded or apiculate base. Simple aperture at the end of a thin neck.

Range and Occurrence: Cosmopolitan from Jurassic to Recent (Bartenstein and Bolli 1986).

Oolina sulcata (Walker and Jacob 1798)

Plate 16, figure 3

Serpula sulcata WALKER and JACOB 1798, pl. 14, fig. 5.

Lagena cf. sulcata (Walker and Jacob). - BARTENSTEIN and BRAND 1951, pl. 10, fig. 281.

Lagena sulcata (Walker and Jacob). — NEAGU 1975, pl. 69, figs. 18-19.

Description: Unilocular, globular test with rounded aperture on short neck. Ten longitudinal ribs ornament the test.

Remarks: Differs slightly from the species illustrated by Bartenstein and Brand (1951) in having a more pointed proximal end.

Range and Occurrence: Late Valanginian in northwestern Germany (Bartenstein and Brand 1951), late Valanginian-early Hauterivian in Rumania (Neagu 1975).

Oolina cf. sulcata (Walker and Jacob 1798)

Plate 16, figure 2

Serpula sulcata WALKER and JACOB 1798, pl. 14, fig. 5.

Lagena sulcata (Walker and Jacob). — WEIDICH 1990, pl. 45, figs. 6, 14.
1 Saracenaria forticosta Bettenstaedt, $(\times 50)$, Sample 766A-47R-01; 98-103cm.

2 Saracenaria forticosta Bettenstaedt, $(\times 50)$, Sample 766A-45R-02; 109-113cm.

3 Saracenaria forticosta Bettenstaedt, $(\times 50)$, Sample 766A-45R-02; 109-113cm.

4 Saracenaria forticosta Bettenstaedt, $(\times 55)$, Sample 766A-47R-01; 98-103cm.

5 Saracenaria forticosta Bettenstaedt, $(\times 65)$, Sample 766A-49R-01; 124-128cm.

6 Saracenaria forticosta Bettenstaedt, $(\times 60)$, Sample 766A-32R-02; 104-108cm.

7 Saracenaria forticosta Bettenstaedt, ( $\times 90)$, holotype. 8a,b Saracenaria erlita Ludbrook, $(\times 145, \times 150)$, Sample 766A-29R-03; 54-58cm.

9 Saracenaria frankei Ten Dam, $(\times 100)$, Sample 766A48R-04; $51-54 \mathrm{~cm}$.

10a,b Saracenaria frankei Ten Dam, $(\times 75, \times 75)$, Sample 766A-47R-01; 98-103cm.

1la,b Saracenaria pravoslavlevi Fursenko and Polenova, (×70), Sample 766A-45R-04; 115-120cm.

12a,b Saracenaria pravoslavlevi Fursenko and Polenova, $(\times 75, \times 70)$, Sample 766A-45R-04; 115-120cm.

13 Saracenaria pravoslavlevi Fursenko and Polenova, (×95), Sample 766A-48R-04; 51-54cm. 


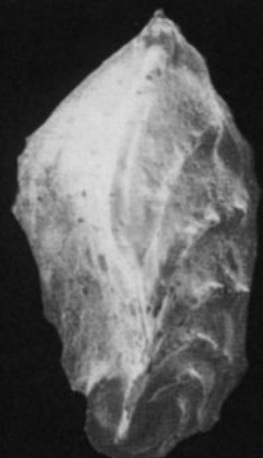

1

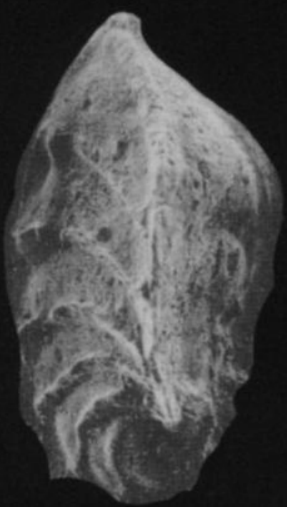

4

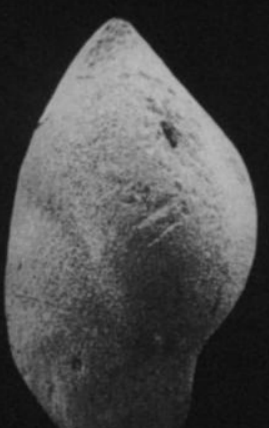

8 a

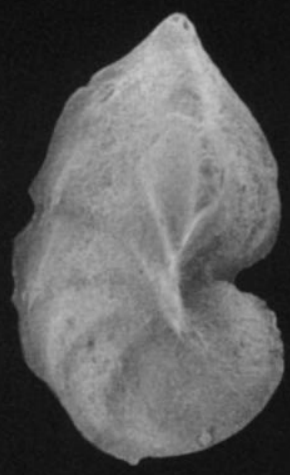

$11 \mathrm{a}$

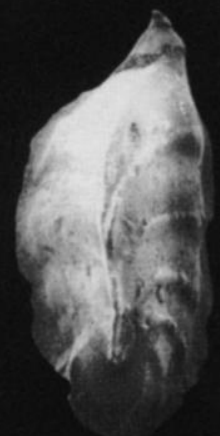

2

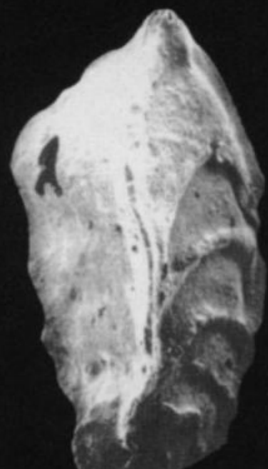

5

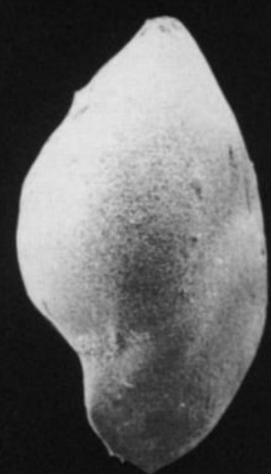

$8 b$
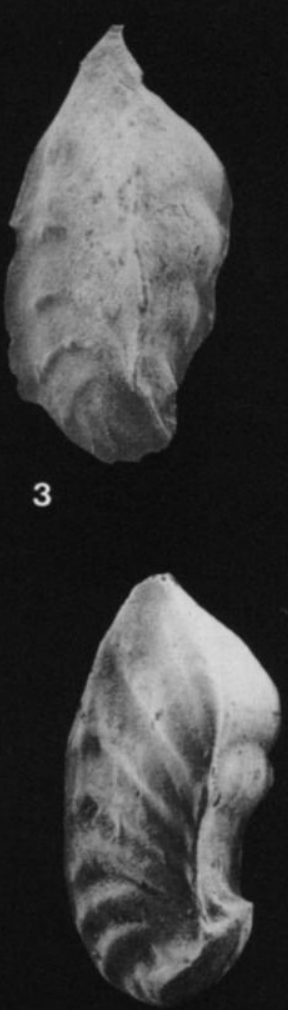

6

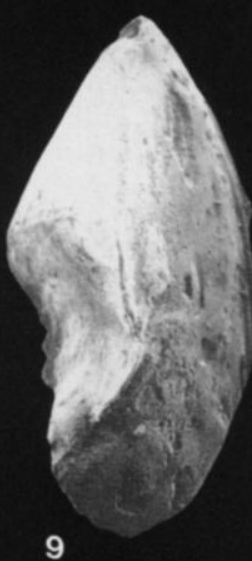

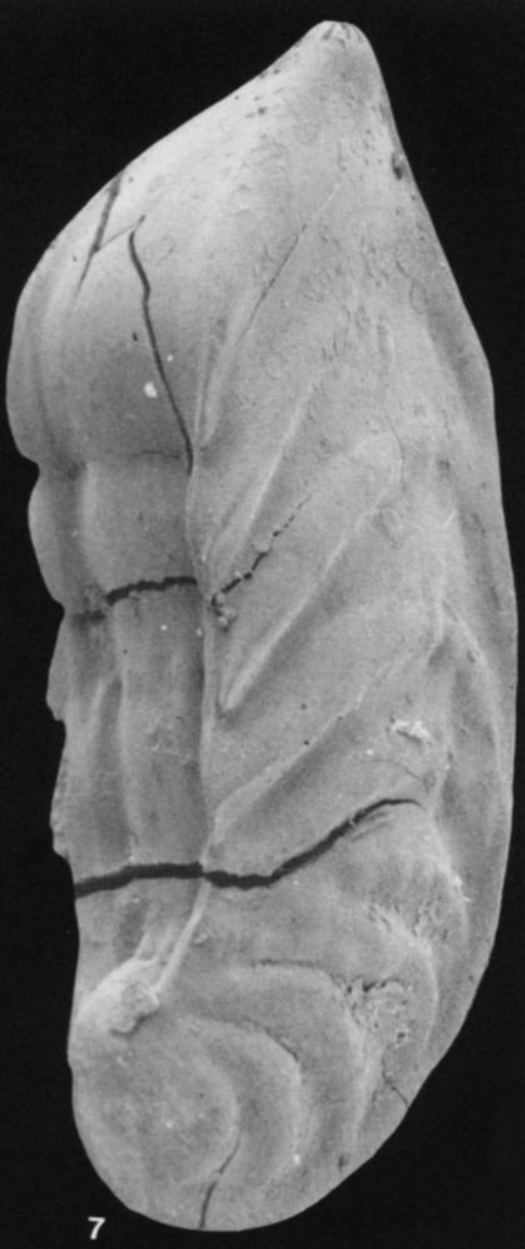
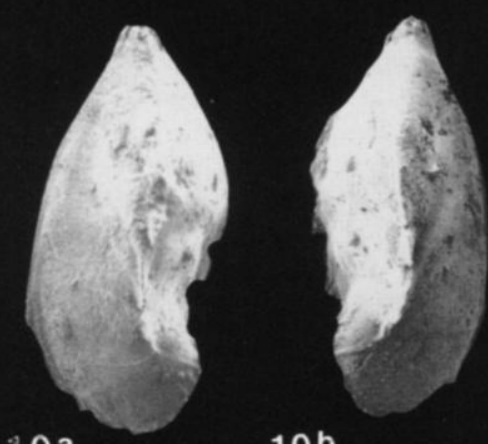

$10 b$

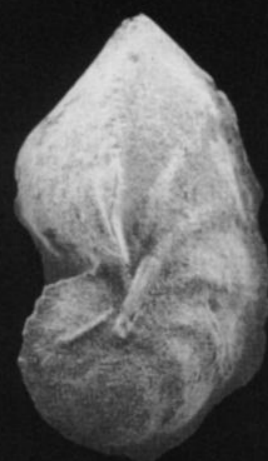

i1 b

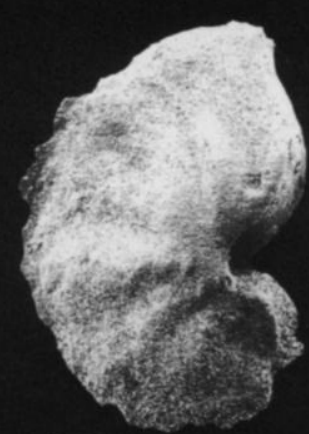

12 a

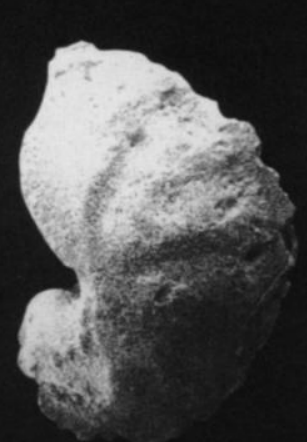

$12 b$

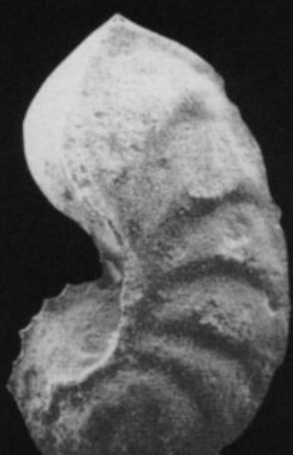


Description: Unilocular, fusiform test, pointed at both ends with six projecting, thin, longitudinal costae reaching a small round aperture.

Remarks: Differs from $O$. sulcata Walker and Jacob by having a less globular test and fewer costae which are more prominently raised.

Range and Occurrence: Late Albian-Cenomanian in the northern Alps (Weidich 1990).

Subfamily ELLIPSOLAGENINAE A. Silvestri 1923

Genus Fissurina Reuss 1850

Fissurina cf. laevigata Reuss 1850

Fissurina cf. laevigata REUSS 1850, pl. 46, fig. 1a, b.

Fissurina laevigata Reuss. - WEIDICH 1990, pl. 45, figs. 7-8.

Description: Ovate test, lenticular in cross section with carinate periphery. Slit-like terminal aperture.

Remarks: Rare at Site 766.

Range and Occurrence: Cretaceous to Holocene (Loeblich and Tappan 1987).

Suborder ROBERTININA Loeblich and Tappan 1984

Superfamily CERATOBULIMINACEA Cushman 1927

Family CERATOBULIMINIDAE Cushman 1927

Subfamily REINHOLDELLINAE Seiglie and Bermúdez 1965

Genus Reinholdella Brotzen 1948

Reinholdella hofkeri (Bartenstein and Brand 1951)

Plate 15 , figure $2 \mathrm{a}, 2 \mathrm{~b}$

Conorbis hofkeri BARTENSTEIN and BRAND 1951, pl. 11, fig. 320.

Reinholdella hofkeri (Bartenstein and Brand). - NEAGU 1975, pl. 107, figs. 1-6; pl. 108, figs. 19-20.

Description: Trochospiral test with five chambers in last whorl and subacute periphery. Sutures fine, radiate and faintly depressed on concave umbilical face; on convex spiral side, sutures thicker, curved and markedly depressed. Interiomarginal aperture.

Remarks: Secondary apertures are rarely visible.

Range and Occurrence: Late Hauterivian-early Barremian in Rumania (Neagu 1975). Berriasian to Valanginian and possibly Hauterivian-Aptian in Tethyan and transitional boreal facies in the northern hemisphere (Bartenstein 1976).

Suborder ROTALIINA Delage and Hérouard 1896

Superfamily CHILOSTOMELLACEA Brady 1881

Family GAVELINELLIDAE Hofker 1956

Subfamily GAVELINELLINAE Hofker 1956

Genus Gavelinella Brotzen 1942

Gavelinella sigmoicosta? (Ten Dam 1948)

Plate 15, figure $1 \mathrm{a}, 1 \mathrm{~b}$

Anomalina sigmoicosta TEN DAM 1948, pl. 32, figs. 23-24.

Gavelinella sigmoicosta (Ten Dam). - BARTENSTEIN and KAEVER 1973, pl. 6, figs. 98-100. - WEIDICH 1990, pl. 28, figs. 21-23.

Lingulogavelinella sigmoicosta (Ten Dam). - NEAGU 1975, pl. 100, figs. $1-29$, pl. 101, figs. 1-34, pl. 102, figs. 6-20; text fig. 22.

Description: Small, disc-shaped test with flat, spiral face (two and a half whorls). Eight chambers in last whorl becoming progressively higher and more inflated, separated by arched sutures, slightly depressed in last chamber; large, open umbilicus and extraumbilical-umbilical, interiomarginal slit-aperture.

Remarks: Poor preservation only allowed tentative determination.

Range and Occurrence: Cosmopolitan and earliest representative of the genus, this species is a useful marker for the late Hauterivianearly Barremian (Zedler 1961; Bartenstein and Kaever 1973; Neagu 1975; Weidich 1990).

Gavelinella barremiana Bettenstaedt 1952

Plate 15, figure $3 a, 3 b$

Gavelinella barremiana BETTENSTAEDT 1952, pl. 2, figs. 26-29.

\section{PLATE 10}

la,b Saracenaria triangularis (d'Orbigny), $(\times 110, \times 110)$, Sample 766A-30R-04; 100-102cm.

2a,b Saracenaria spinosa (Eichenberg), $(\times 115, \times 115)$, Sample 766A-30R-04; 100-102cm.

3a,b Saracenaria valanginiana Bartenstein and Brand, $(\times 85$, $\times 85$ ), Sample 766A-32R-05; 5-8cm.

4a,b Saracenaria valanginiana Bartenstein and Brand, $(\times 55$, $\times 50$ ), Sample 766A-40R-02; 46-50cm.

5 Saracenaria valanginiana Bartenstein and Brand, (×50), Sample 766A-40R-02; 46-50cm.
6 Saracenaria valanginiana Bartenstein and Brand, (×280), holotype.

$7 \quad$ Saracenaria sp., $(\times 40)$, Sample 766A-46R-03; $122-$ $125 \mathrm{~cm}$.

8 Saracenaria sp., $(\times 40)$, Sample 766A-34R-02; 30$33 \mathrm{~cm}$.

9 Saracenaria sp., $(\times 45)$, Sample 766A-45R-04; $115-$ $120 \mathrm{~cm}$.

10a,b Saracenaria sp. 1, $(\times 55, \times 55)$, Sample 766A-32R-05; $5-8 \mathrm{~cm}$.

11 Saracenaria sp. 2, (×60), Sample 766A-30R-04; 100$102 \mathrm{~cm}$. 


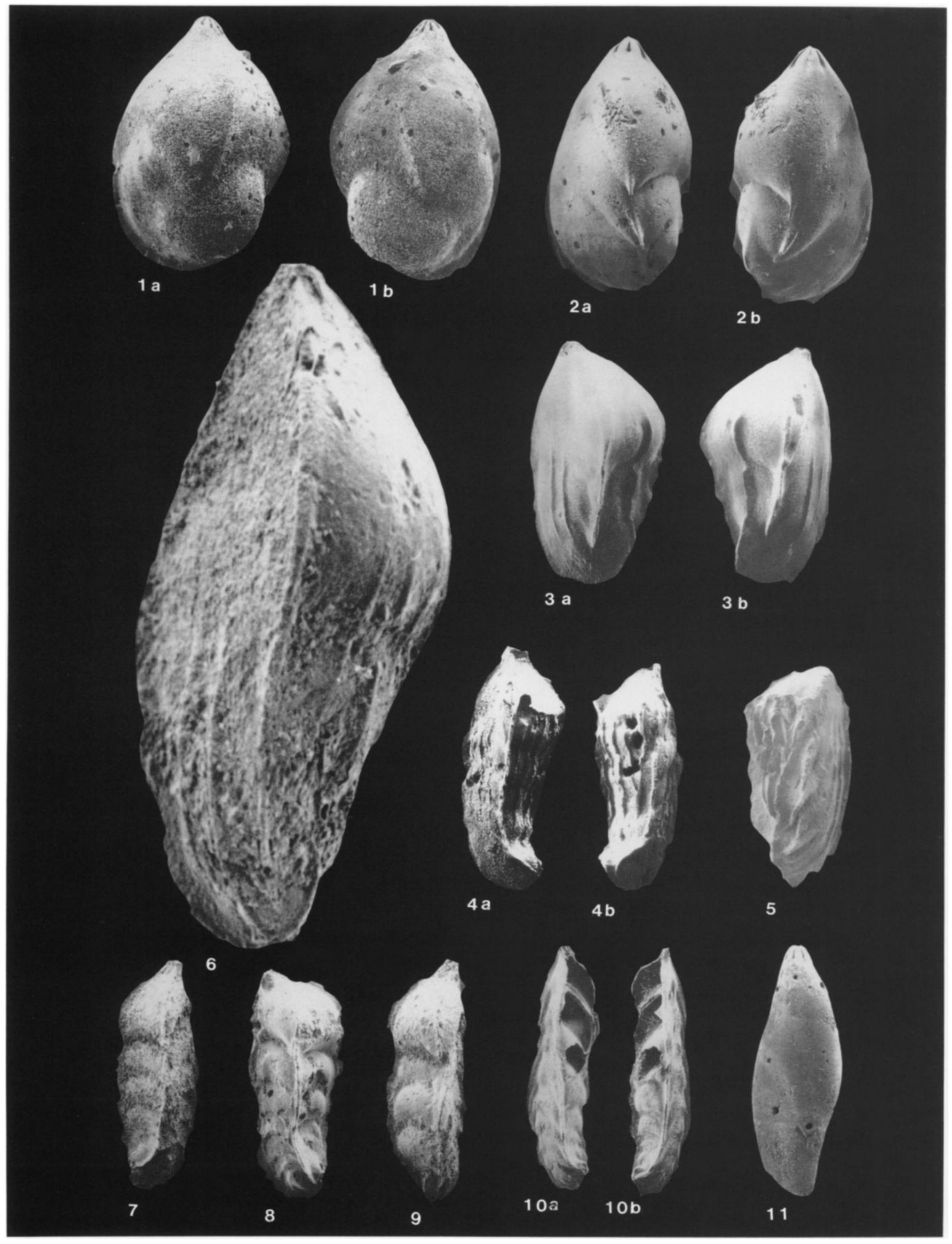


Lingulogavelinella barremiana (Bettenstaedt). - NEAGU 1975, pl. 89, figs. 20-27, pl. 99, figs. 1-26, pl. 102, figs. 1-5; text fig. 22.

Description: Small, disc-shaped test with slightly convex spiral face (two and a half whorls). Twelve chambers in the last whorl becoming progressively larger and more inflated, separated by sutures, more markedly depressed towards the umbilicus. Large, open umbilicus and extraumbilical, interiomarginal slit-aperture with lip extended to the umbilicus.

Remarks: This cosmopolitan species probably evolved from $G$. sigmoicosta in the late Barremian (Neagu 1975). The species reported by Riegraf (1989) from the upper Hauterivian in ODP Sites may be a precursor to G. barremiana (Moullade, pers. comm. 1994).

Range and Occurrence: A useful marker for the late Barremian to early Aptian in northern Germany (Bettenstaedt 1952).

\section{ACKNOWLEDGMENTS}

Grateful thanks are due to the Ocean Drilling Program and especially to Dr. F. M. Gradstein (Co-chief Scientist of ODP Leg 123) for making the ODP Site 766 material available for study, to Dr. H. Malz and Dr. T. Jellinek for their kind assistance while examining collections housed at the Senckenberg Museum in Frankfurt and for providing S.E.M. photographs of some of the holotypes, to Prof. H. Luterbacher for making available for reference at Tübingen University his collections of Lower Cretaceous foraminifera, to Prof. W. Kuhnt and to Dr. W. Werner for allowing access to the late Prof. Weidich's collections at the Bäyerische Staatssammlung für Paläontologie und historische Geologie in Munich, to Prof. T. Neagu for his advice regarding the taxonomy, to Dr. P. R. Bown for nannofossil determinations, and to Prof. A. $R$. Lord of University College London for his help and encouragement. We are very grateful to Profs. W. Kuhnt, M. Moullade, T. Neagu, and Drs. F. M. Gradstein and D. H. McNeil, who read an early version of the manuscript and made many helpful suggestions.

Jim Davy and Toby Stiles are thanked for their assistance with S.E.M. microscopy and photographic work, Danuta Kaminski for help with the preparation of the samples, and Rob Holbourn for help with the plates.

A.E.L.H. gratefully acknowledges support of a Research Studentship from the Natural Environment Research Council and financial support from the Graduate School of University College, London and the Grzybowskii Foundation. M.A.K. acknowledges support from the Natural Environment Research Council for studies of the Lower Cretaceous of the Indian Ocean (Small Grant no. GST/02/580).

\section{REFERENCES}

ASCOLI, P., 1976. Foraminiferal and ostracod biostratigraphy of the Mesozoic-Cenozoic, Scotian Shelf, Atlantic Canada. In: Schafer, C. T. and Pelletier, B. R., Eds., Proceedings of the $1^{\text {st }}$ International Symposium on Benthic Foraminifers of continental margins, Part B: Palaeoecology and Biostratigraphy, Maritime Sediments, Special Publication n ${ }^{\circ}$ 1:653-671.

ASCOLI, P., 1988. Berriasian and Valanginian foraminiferal zonation of the N.W. Atlantic margin of North America. Revue de Paléobiologie, Vol. 2, 'Benthos 86:271-280.

AZBEL', A.Ya. and GRIGALIS, A. A., Eds., 1991. Prackticheskoe rukovodstvo po mikrofaune SSSR, Vol. 5 - Foraminifery Mezozoya. Ministry of Geology of the USSR. Leningrad: Nedra, 1-375.

AUBERT, J. and BARTENSTEIN, H., 1976. Lenticulina (L.) nodosa additional observations in the worldwide Lower Cretaceous. Bulletin du Centre de Recherche de Pau. S.N.P.A., 10:1-33.

BACH, H., HAGENMEYER, P. and NEUWEILER, F., 1959. Neuebeschreibung und Revision einiger Foraminiferenarten und -unterarten aus dem schwäbischen Lias. Geologisches Jahrbuch, 76:427-452.

BARTENSTEIN, H., 1952. Taxonomische Revision und Nomenklator zu Frank E. Hecht "Standard-Gliedrung der Nordwestdeutschen Unterkreide nach Foraminifera" (1938). Teil 1. Hauterive. Senckenbergiana, 33(1-3):297-312.

1954. Revision von Berthelins Mémoire 1880 über die Alb. foraminiferen von Montcley. Senckenbergiana lethaea, 35(1-2):37-50.

\section{PLATE 11}

la,b Palmula sp. 1, $(\times 75, \times 75)$, Sample 766A-32R-05; 5$8 \mathrm{~cm}$.

2a,b Astacolus calliopsis (Reuss), $(\times 95, \times 100)$, Sample 766A-29R-03; 54-58cm.

3 Astacolus calliopsis (Reuss), $(\times 80)$, Sample 766A-29R$03 ; 54-58 \mathrm{~cm}$.

4 Astacolus calliopsis ((Reuss), (×75), Sample 766A29R-03; 54-58cm.

5 Astacolus calliopsis (Reuss), $(\times 85)$, Sample 766A-29R$03 ; 54-58 \mathrm{~cm}$.

6a,b Astacolus schlönbachi (Reuss), $(\times 100, \times 100)$, Sample 766A-28R-01; $21-25 \mathrm{~cm}$. 7a,b Marginulina bullata Reuss, $(\times 110, \times 115)$, Sample 766A-33R-02; $15-18 \mathrm{~cm}$.

8a-c Marginulina sp. $1,(\times 90, \times 85, \times 900)$, Sample 766A44R-03; 47-52cm.

9a,b Vaginulinopsis excentrica (Cornuel), $(\times 75, \times 80)$, Sample 766A-45R-04; $115-120 \mathrm{~cm}$.

10 Marginulina pyramidilis (Koch), $(\times 140)$, Sample 766A-30R-03; 44-47cm.

11ab Vaginulinopsis excentrica (Cornuel), $(\times 90, \times 90)$, Sample 766A-45R-04; $115-120 \mathrm{~cm}$.

12 Marginulina inaequalis Reuss, $(\times 60)$, Sample 766A33R-02; $15-18 \mathrm{~cm}$. 


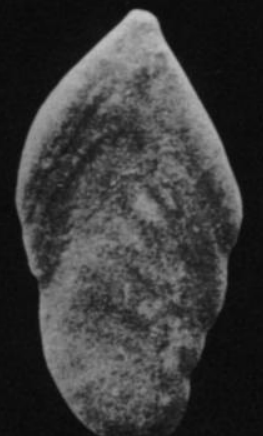

1 á

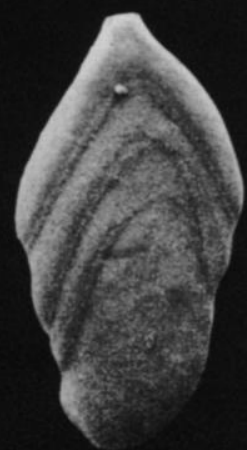

$1 \mathrm{~b}$

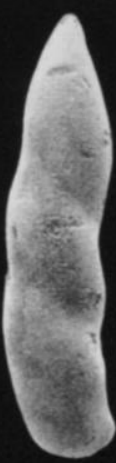

2 a

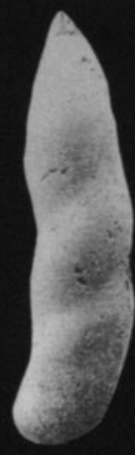

$2 \mathrm{~b}$

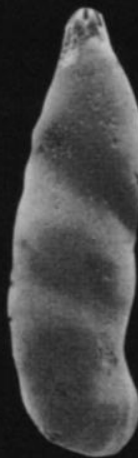

3

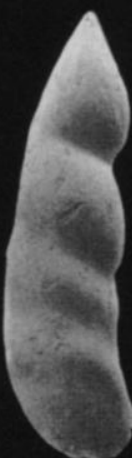

4
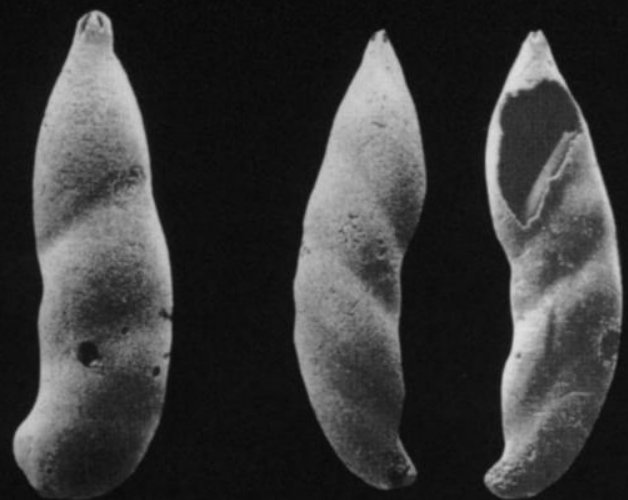

5

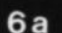

$6 \mathrm{~b}$

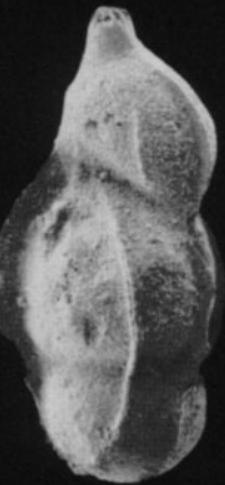

$8 \mathbf{a}$

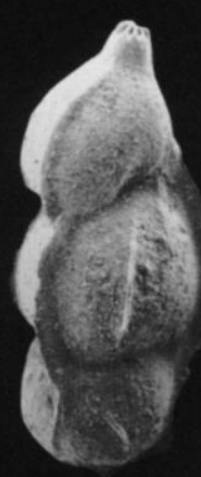

$8 b$

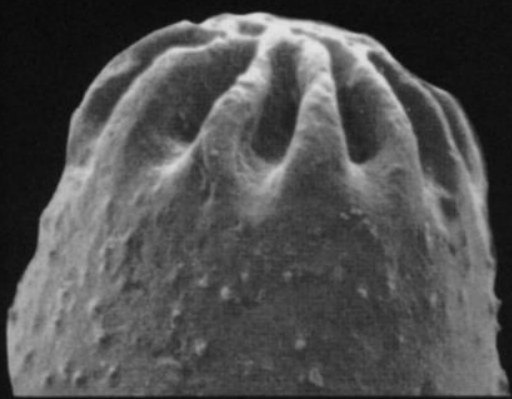

$s$

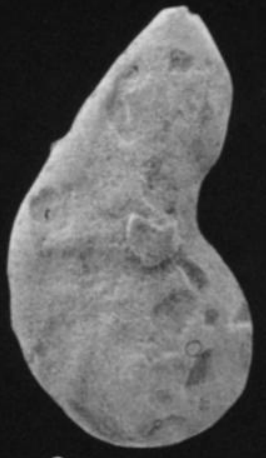

9 a

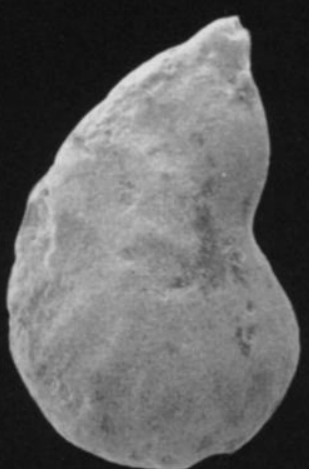

11

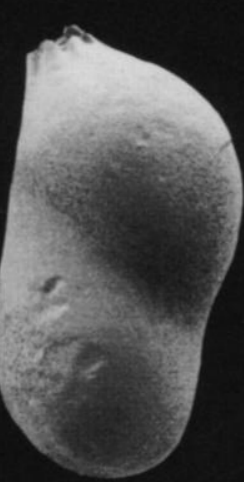

$7 \mathbf{a}$

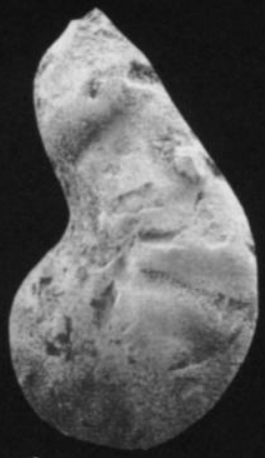

$9 \mathrm{~b}$

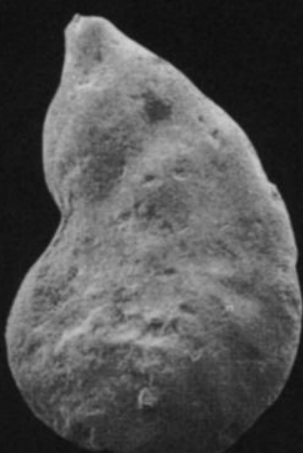

11

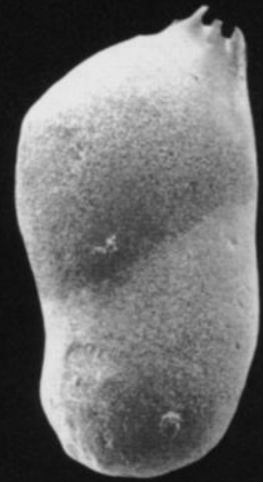

$7 \mathrm{~b}$
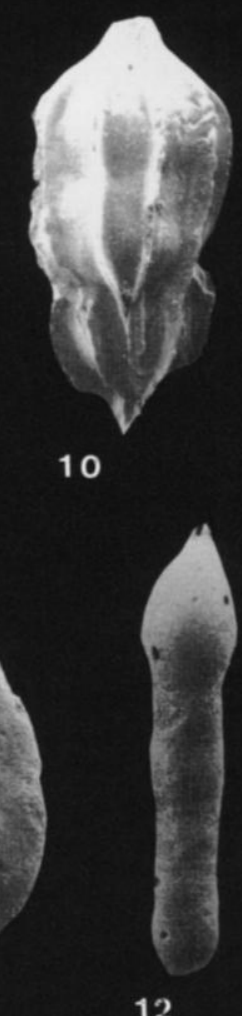
1962. Neue Foraminiferen aus Unterkreide und Oberkeuper NWDeutschlands und der Schweiz. Senckenbergiana lethaea, 43(2):135-149.

1974a. Lenticulina (Lenticulina) nodosa (Reuss 1863) and its sub-species -worldwide index foraminifera in the Lower Cretaceous. Eclogae Geologicae Helvetiae, 67/3:539-562.

- 1974b. Upper Jurassic-Lower Cretaceous primitive arenaceous Foraminifera from DSDP Sites 259 and 261, Eastern Indian Ocean. In: Veevers, J. J. Heirtzler, J. R. et al., Initial Reports of the Deep Sea Drilling Project, Volume 27:683-695. Washington, D.C.: U.S. Government Printing Office.

- 1976. Foraminiferal zonation of the Lower Cretaceous in North West Germany and Trinidad, West Indies, an attempt. Neues Jahrbuch für Geologie und Paläontologie, Monatshefte, fasc. 3:187-191.

1977. Stratigraphic parallelisation of the Lower Cretaceous in the northern hemisphere. Zonation with benthonic foraminifera. Newsletter on Stratigraphy, 14(2):110-117.

1978. Phylogenetic sequences of Lower Cretaceous benthic foraminifera and their use in biostratigraphy. Geologie en Mijnbouw, 57(1):19-24.

1979. Worldwide zonation of the Lower Cretaceous using benthic foraminifera. Newsletters on Stratigraphy, 7(3):142-154.

BARTENSTEIN, H. and BETTENSTAEDT, F., 1962. Marine Unterkreide (Boreal and Tethys). In: Simon, W. and Bartenstein, H., Eds., Leitfossilen der Mikropaläontologie. Berlin: Gebruder Borntraeger, 225-298.

BARTENSTEIN, H. and BOLLI, H. M., 1977. The Foraminifera in the Lower Cretaceous of Trinidad, W.I. -Part 4: Cuch Formation, upper part: Leupoldina protuberans Zone. Eclogae Geologicae Helvetiae, 70(3):543-573.

, 1986. The Foraminifera in the Lower Cretaceous of Trinidad, W.I Part 5: Maridale Formation, upper part; Hedbergella rohri zone. Eclogae Geologicae Helvetiae, 79/3:945-999.
BARTENSTEIN, H. and BRAND, E., 1951. Mikropaläontologie Untersuchungen zur Stratigraphie des nordwestdeutschen Valendis. Abhandlungen der Senckenbergischen Naturforschenden Gesellschaft, 485:239-336.

1952. Nomina nova für Foraminiferen-Homonyme zu Bartenstein and Brand 1951, Valendis. Senckenbergiana, 33(4-6):342-343.

BARTENSTEIN, H. and KAEVER, M., 1973. Die Unterkreide von Helgoland und ihre mikropaläontologische Gliederung. Senckenbergiana lethaea, 54(2-4):207-264.

BARTENSTEIN, H. and KOVATCHEVA, T., 1982. A comparison of Aptian Foraminifera in Bulgaria and North West Germany. Eclogae Geologicae Helvetiae, 75/3:621-667.

BARTENSTEIN, H.and OERTLI, H. J., 1977. Textularia bettenstaedti $\mathrm{n}$. sp. approved benthonic index in the Central European Lower Cretaceous. Neues Jahrbuch für Geologie und Paläontologie, Monatshefte, 1977, $\mathrm{n}^{\circ}$ $1: 15-24$.

BARTENSTEIN, H., BETTENSTAEDT, F. and BOLLI, H. M., 1957. Die Foraminiferen der Unterkreide von Trinidad, B.W.I. Erster Teil: Cucheund Toco- Formation. Eclogae Geologicae Helvetiae, 50:5-67.

, 1966. Die Foraminiferen der Unterkreide von Trinidad, W.I. Eclogae Geologicae Helvetiae, 59/1:129-177.

BAUMGARTNER, P.O., BOWN, P., MARCOUX, J., KAMINSKI, M. A., HAIG, D. and McMINN, A., 1992. Early Cretaceous biogeographic and oceanographic synthesis of Leg 123 (off northwestern Australia). In: Gradstein, F., Ludden, J. N. et al., 1992. Proceedings of the Ocean Drilling program, Scientific Results, 123:739-758. College Station, TX: Ocean Drilling Program.

BERTHELIN, M., 1880. Mémoire sur les foraminiferes fossiles de l' étage Albien de Montcley (Doubs). Mémoires de la Société Géologique de France, série 3, 1(5):1-84.

\section{PLATE 12}

la,b Vaginulinopsis excentrica (Cornuel), $(\times 105, \times 110)$, Sample 766A-44R-05; 102-106cm.

2a,b Vaginulinopsis sp., $(\times 90, \times 90)$, Sample 766A-45R-04; $115-120 \mathrm{~cm}$.

3 Vaginulinopsis excentrica (Cornuel), $(\times 60)$, Sample 766A-32R-05; 5-8cm.

4a,b Vaginulinopsis neopachynota Bartenstein and Kaever, $(\times 90, \times 90)$, Sample 766A-32R-02; 104-108cm.

5 Vaginulinopsis neopachynota Bartenstein and Kaever, (×65), Sample 766A-28R-01; 21-25cm.

6 Vaginulinopsis sp., $(\times 80)$, Sample 766A-44R-03; 47$52 \mathrm{~cm}$.

7a,b Vaginulinopsis humilis precursoria Bartenstein and Brand, $(\times 100, \times 105)$, Sample 766A-32R-05; 5-8cm.
8 Vaginulinopsis humilis precursoria Bartenstein and Brand, $(\times 120)$, Sample 766A-40R-01; 84-88cm.

9a,b Vaginulinopsis reticulosa Ten Dam, $(\times 120, \times 120)$, Sample 766A-47R-04; $114-119 \mathrm{~cm}$.

10 Vaginulinopsis reticulosa Ten Dam, $(\times 75)$, Sample 766A-43R-04; 36-40cm.

11 Vaginulinopsis reticulosa Ten Dam, $(\times 100)$, Sample 766A-36R-01; 70-74cm.

12 Vaginulinopsis reticulosa Ten Dam, $(\times 100)$, Sample 766A-43R-05; 131-135cm.

13 Vaginulinopsis sp., $(\times 150)$, Sample 766A-47R-03; 25$30 \mathrm{~cm}$. 


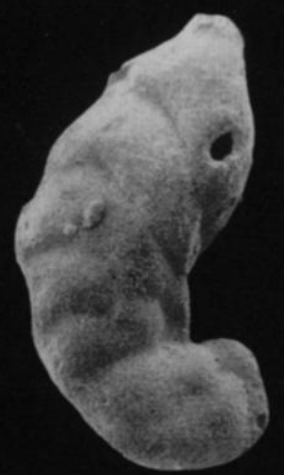

1 a

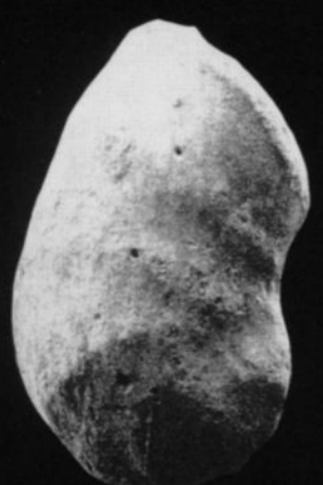

$4 a$

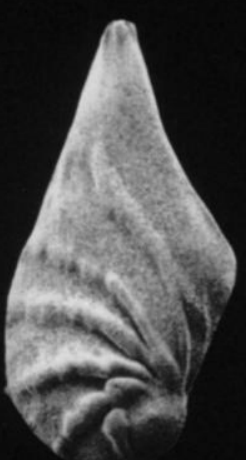

$7 a$

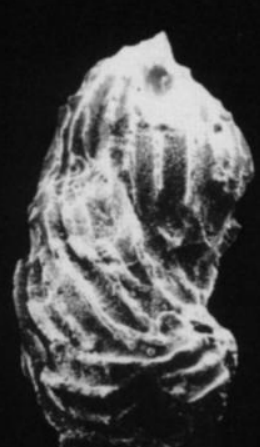

10

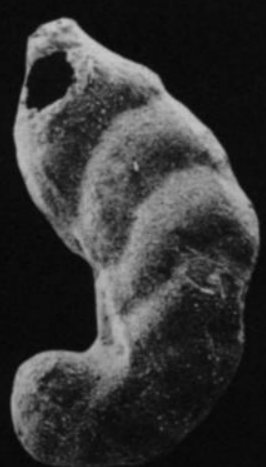

$1 \mathrm{~b}$

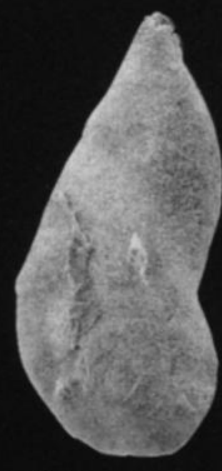

$2 \mathbf{a}$

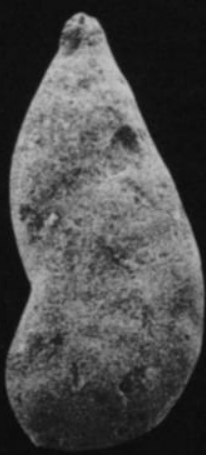

2 b

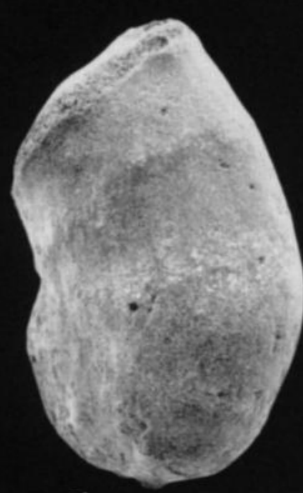

$4 b$

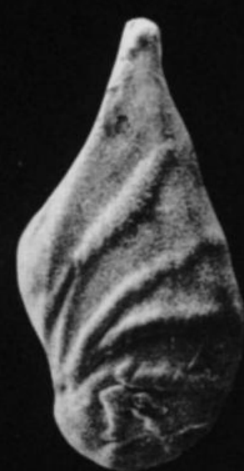

$7 \mathrm{~b}$

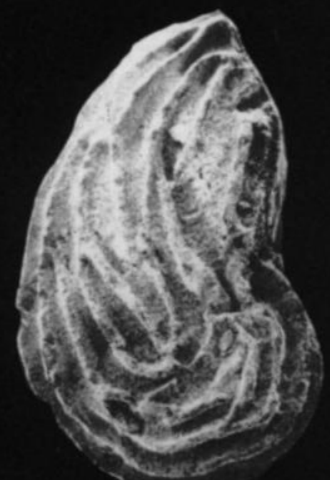

11

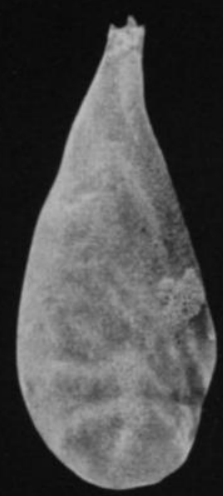

8

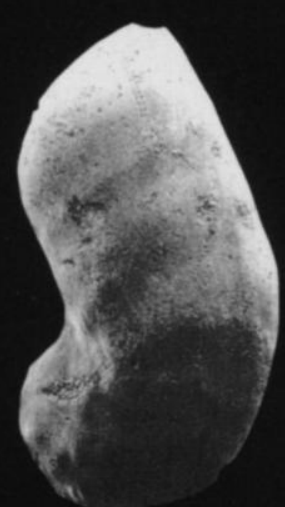

5

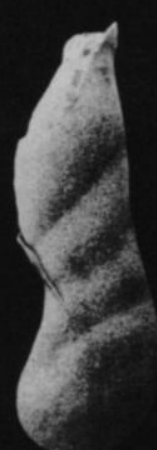

3

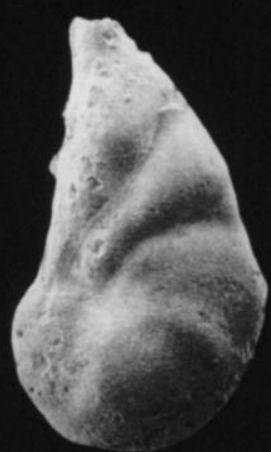

6

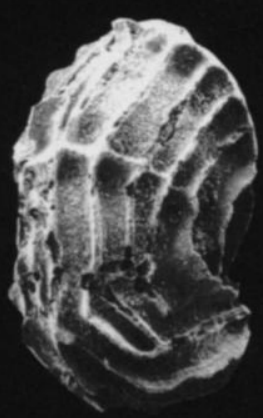

$9 a$

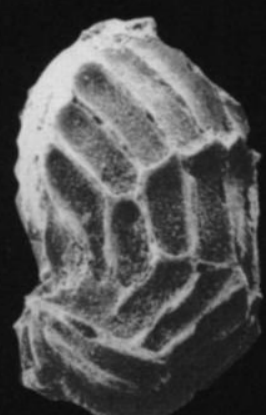

$9 b$

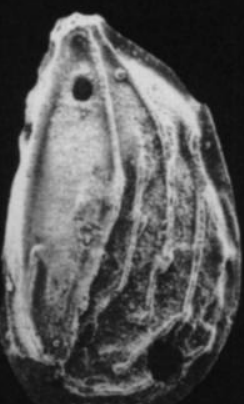

13 
BETTENSTAEDT, F., 1952. Stratigraphische wichtige Foraminiferen-Arten aus dem Barrême vorwiegend Norwest-Deutschlands. Senckenbergiana, 33(4-6):263-295.

BERGGREN, W. A. and KAMINSKI, M. A., 1990. Abyssal Agglutinates: Back to basics. In: Hemleben, C., Kaminski, M. A., Kuhnt, W. and Scott, D. B., Eds., Palaeoecology, Biostratigraphy, Palaeoceanography and Taxonomy of Agglutinated foraminifera. NATO ASI Series C 327:53-75. Kluwer Academic Publishers.

BORNEMANN, L. G., 1854. Über die Liasformation in der Umgegend von Göttingen und ihre organischen Einschlüsse. Berlin, 1-77.

BRADY, H. B., 1879. Notes on some of the reticularian Rhizopoda of the "CHALLENGER" Expedition; Part I. On new or little known Arenaceous types. Quarterly Journal of Microscopical Sciences, 19:20-63.

BRAND, E. and OHMERT, W., 1992. Die netzgerippten Lenticulinen im Dogger von Nordwest- und Südwest- Deutschland. Senckenbergiana lethaea, 72:7-36

BUFFLER, R. T., ROWELL, P. and EXON, N., 1992. Seismic stratigraphy of the Site 766 area, western margin of the Exmouth Plateau, Australia. In: Gradstein, F. Ludden, J. N. et al., 1992. Proceedings of the Ocean Drilling program, Scientific Results, 123:563-582. College Station, TX: Ocean Drilling Program.

CHAPMAN, F., 1891-1898. The Foraminifera of the Gault of Folkestone. Journal of the Royal Microscopical Society, London, Pt. 1-10.

$\rightarrow$ CLARK, F. E. and PATTERSON, R. T., 1993. An illustrated key to the identification of unilocular genera of calcareous foraminifera. Journal of Palaeontology, 67(1):20-28.

CORNUEL, J., 1848. Description des nouveaux fossils microscopiques du terrain crétacé inférieur du Département de la Haute-Marne (Wassy). Mémoires de la Société Géologique de France, (2) 3:1-242.

CRESPIN, I., 1944. Some Lower Cretaceous Foraminifera from bores in the Great Artesian Basin, northern New South Wales. Journal and Proceedings of the Royal Society of New South Wales, vol. 78:17-24.

1953. Lower Cretaceous Foraminifera from the Great Artesian Basin, Australia.Contributions of the Cushman Foundation for Foraminiferal Research, 4:26-36.
1963. Lower Cretaceous Arenaceous Foraminifera of Australia. Bureau of Mineral Resources Geology and Geophysics of Australia, Bulletin 66:1-110.

CUSHMAN, J. A. and ALEXANDER, C. I., 1930. Some Vaginulinas and other foraminifera from the Lower Cretaceous of Texas. Contributions from the Cushman Laboratory for Foraminiferal Research, 6(1):1-10.

CUSHMAN, J. A. and JARVIS, P. W., 1928. Cretaceous foraminifera from Trinidad. Contributions from the Cushman Laboratory for Foraminiferal Research, 4:85-103.

DIENI, I. and MASSARI, F., 1966. I foraminiferi del Valanginiano superiore di Oresei (Sardegna). Palaeontographica italica, 61, n. ser. 31:75-186.

DYLAZANKA, M., 1923. Warstwy inoceramowe z lomu w Szymbarku kolo Gorlic. Rocznik Polskiego Towarzystwa Geologicznego, 1: 36-80.

EICHENBERG, W., 1933. Die Erforschung der Mikroorganismen, insbesondere der Foraminiferen der norddeutschen Erdölfelder. Teil I. Die Foraminiferen der Unterkreide. Folge 2 - Foraminiferen aus dem Barrême von Wenden am Mittelandkanal. Jahresberichte der niedersachsischen geologischen Vereinigung, 25:167-200.

1935. Mikrofaunen-Tafeln zur Bestimmung von Unterkreide-Horizonten in Bohrkernen norddeutscher Oelfelder. Oel und Kohle, 11(23):388-412

ESPITALIÉ, J. and SIGAL, J., 1963. Contribution à l'étude des foraminifères (Micropaléontologie-Microstratigraphie) du Jurassique supérieur et du Néocomien du Bassin de Majunga (Madagascar). Annales géologiques de Madagascar, 32:1-100.

$\rightarrow$ EICHER, D. L. and WORSTELL, P., 1970. Cenomanian and Turonian Foraminifera from the Great Plains, United States. Micropaleontology, $16: 269-324$

EXTON, J., 1979. Pliensbachian and Toarcian Mikrofauna of Zambujal, Portugal: Systematic Paleontology. Geological Paper 79-1. Carleton University Department of Geology, Ottawa, Canada:1-104.

FOWLER, S. P. and BRAUN, W. K., 1993. Hauterivian to Barremian Foraminifera and Biostratigraphy of the Mount Goodenough Formation, Aklavik Range, Northwestern District of Mackenzie. Geological Survey of Canada, Bulletin 443:1-83.

\section{PLATE 13}

la,b Citharina rudocosta Bartenstein and Brand, $(\times 45, \times 45)$, Sample 766A-48R-02; 95-98cm.

2 Citharina sp. 1, (×85), Sample 766A-44R-03; 47-52cm.

3a,b Planularia complanata (Reuss), $(\times 80, \times 80)$, Sample 766A-45R-04; 115-120cm.

$4 \quad$ Planularia complanata (Reuss), $(\times 75)$, Sample 766A40R-01; 84-88cm.

5a,b Planularia complanata (Reuss), $(\times 90, \times 95)$, Sample 766A-46R-03; $122-125 \mathrm{~cm}$. 6a,b Planularia complanata (Reuss), $(\times 95, \times 90)$, Sample 766A-47R-03; 25-30cm.

$7 \quad$ Lenticulina guttata (Ten Dam), $(\times 75)$, Sample 766A32R-05; 5-8cm

8ac Lenticulina guttata (Ten Dam), $(\times 100, \times 100, \times 600)$, Sample 766A-32R-05; 5-8cm.

9a,b Planularia crepidularis Roemer, $(\times 130, \times 130)$, Sample 766A-32R-05; 5-8cm.

10a,b Planularia crepidularis Roemer, $(\times 95, \times 90)$, Sample 766A-43R-02; 46-50cm. 


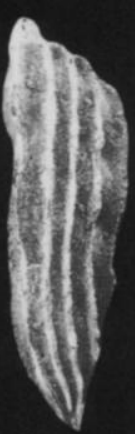

1 a

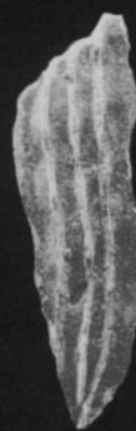

$1 \mathrm{~b}$

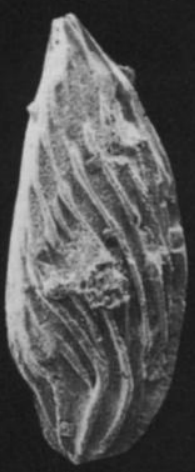

2

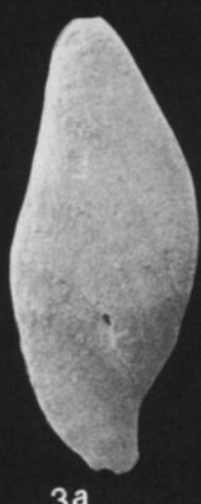

$3 a$

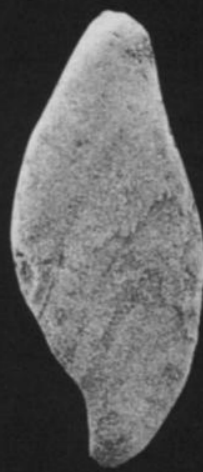

$3 \mathbf{b}$

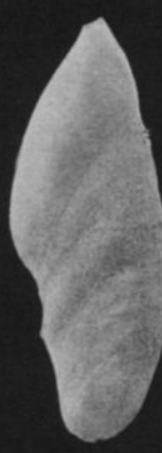

4

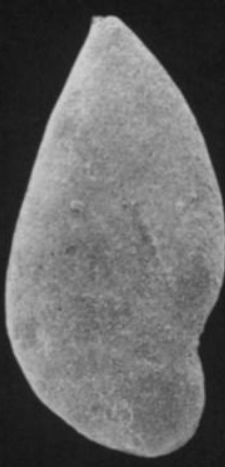

5 a

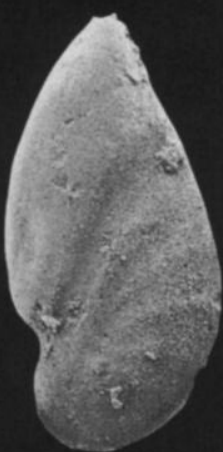

$5 \mathrm{~b}$

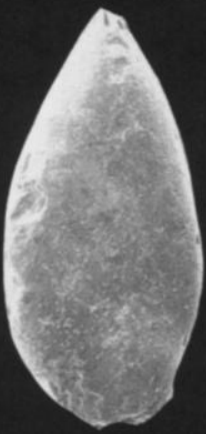

$6 a$

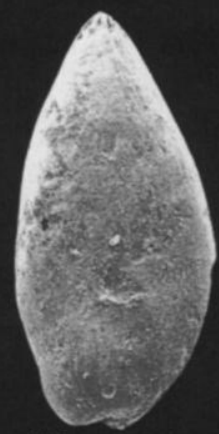

$6 \mathrm{t}$

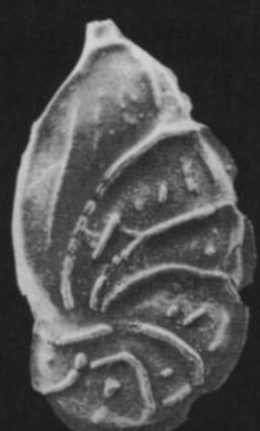

7

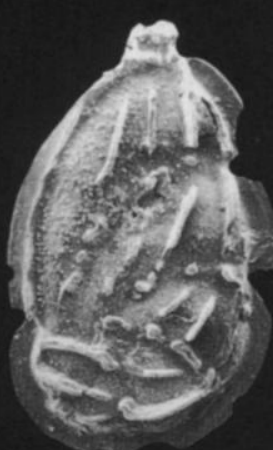

8 a

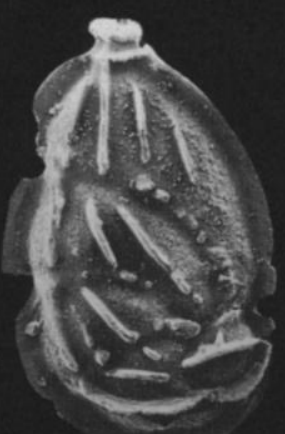

$8 b$

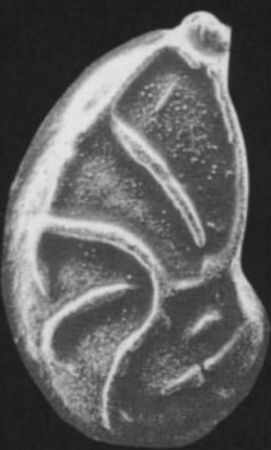

9 a

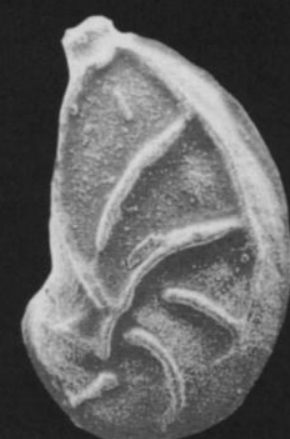

$9 b$

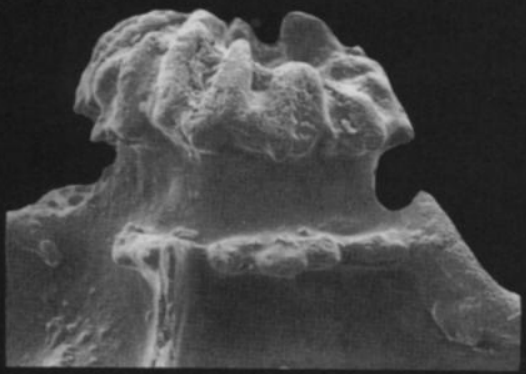

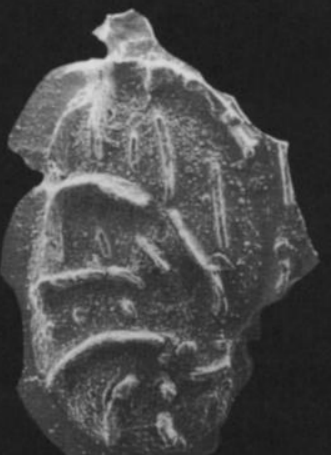

$10 \mathrm{a}$

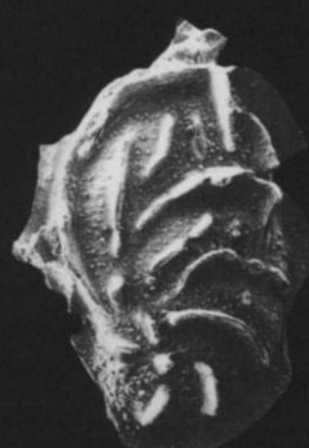

$10 \mathrm{~b}$ 
FRAKES, L. A. and FRANCIS, J. E., 1988. A guide to Phanerozoic cold polar climates from high-latitude ice-rafting in the Cretaceous. Nature, 333:547-549.

FRAKES, L. A., FRANCIS, J. E. and SYKTUS, J. I., 1992. Climate Modes of the Phanerozoic. The history of the Earth's climate over the past 600 millions years. Cambridge University Press, 1-221.

FUCHS, W. and STRADNER, H., 1967. Die Foraminiferenfauna und Nannoflora eines Bohrkernes aus dem höheren Mittel-Alb der Tiefbohrung DELFT 2 (NAM), Niederlande. Jahrbuch der Geologischen Bundesanstat, 110:225-341.

FURSENKO, A. V. and POLENOVA, E. N., 1950. Foraminifera of the Lower Volgian beds of the Embensk District (Indersk Lake Region). Trudy Vsesoyuznogo Neftyanogo Nauchno - issledovatel' skogo Geologorazvedochnogo Instituta (VNIGRI), new series, 49:5-92 (in Russian).

GLAESSNER, M. F., 1937. Studien über Foraminiferen aus der Kreide und dem Tertiär des Kaukasus; 1. Die Foraminiferen der ältesten Tertiärschichten des Nordwest-Kaukas. Problems of Paleontology, 2-3, Moscow, 349-408.

GRADSTEIN, F. M., 1983. Paleoecology and stratigraphy of Jurassic abyssal foraminifera in the Blake Bahama-Basin foraminifers Deep Sea Drilling Project Site 534. In: Sheridan, R. E. and Gradstein, F. M. et al., Initial Reports of the Deep Sea Drilling Project, Volume 76:537-559. Washington, D.C.: U.S. Government Printing Office.

GÜMBEL, C. W., 1862. Die Streitberger Schwammlager und ihre Foraminiferen-einschlüsse. Jahreshefte des Vereins für Vaterländische Naturkunde im Württemberg, 18:192-238.

HAIG, D. W., 1979. Global distribution patterns for mid-Cretaceous foraminiferids. Journal of Foraminiferal Research, 9, $\mathrm{n}^{\circ}$ 1:29-40.

1980. Early Cretaceous textulariine foraminiferids from Queensland. Palaeontographica Abt. A, 170, Lfg. 4-6:87-138.

$\rightarrow \longrightarrow, 1981$. Mid-Cretaceous foraminiferids from the Wahgi Valley, Central Highlands of Papua New Guinea. Micropaleontology, 27(4):337-351.

1982. Early Cretaceous Milioline and Rotaliine Benthic Foraminiferids from Queensland. Palaeontographica, Abt. A, 177:1-88.

1992. Aptian-Albian foraminifers from Site 766, Cuvier Abyssal Plain, and comparison with coeval faunas from the Australian region. In:
Gradstein, F. Ludden, J. N. et al., 1992. Proceedings of the Ocean Drilling program, Scientific Results, 123: 271-297. College Station, TX: Ocean Drilling Program.

HAIG, D. W. and LYNCH, D. A., 1993. A late early Albian marine transgressive pulse over northeastern Australia, precursor to epeiric basin anoxia: Foraminiferal evidence. Marine Micropaleontology 22:311-362.

HART, M. B., BAILEY, H. W., CRITTENDEN, S., FLETCHER, B. N., PRICE, R. J. and SWIECIKI, A., 1989. Cretaceous. In: Jenkins, D. G. and Murray, J. W., Eds. Stratigraphical atlas of fossil foraminifera, 2nd edition. London: Ellis Horwood Ltd., 273-371.

JENDRYKA-FUGLEWICZ, B., 1975. Evolution of the Jurassic and Cretaceous smooth-walled Lenticulina (Foraminiferia) of Poland. Acta Palaeontologica Polonica, 20, $n^{\circ}$ 2:99-197.

JONES, J. P. and PARKER, W. K., 1860. On the Rhizopodal fauna of the Mediterranean compared with that of the Italian and some other Tertiary deposits. Quarterly Journal of the Geological Society of London, 16:292307.

KAMINSKI, M. A. and GEROCH, S., 1992. The use of deep-water agglutinated foraminifera in correlating Lower Cretaceous pelagic and flysch sequences: current status and prospects for the future. Cretaceous Research 13:453-466.

1993. A revision of foraminiferal species in the Grzybowski Collection. In: Kaminski, M. A., Geroch, S. and Kaminski, D. G., 1993. The origins of Applied Micropalaeontology: the school of Josef Grzybowski. Grzybowski Foundation Special Publication No. 1:239-324.

KAMINSKI, M. A., GRADSTEIN, F. and GEROCH, S., 1992. Uppermost Jurassic to Lower Cretaceous deep-water benthic foraminiferal assemblages from Site 765 on the Argo Abyssal Plain. In: Gradstein, F., Ludden, J. N. et al., 1992. Proceedings of the Ocean Drilling program, Scientific Results, 123:239-269. College Station, TX: Ocean Drilling Program.

KING, C., BAILEY, H. W., BURTON, C. A. and KING, A. D., 1989. Cretaceous of the North Sea. In: Jenkins, D. G. and Murray, J. W., Eds., Stratigraphical atlas of fossil foraminifera, 2nd edition. London: Ellis Horwood Ltd., pp. 372-417.

KOCH, F. C. L., 1851. Über einige neue Versteinerungen und die Perna Mulletti DESH. aus dem Hiltsthon vom Elligser Brink und von holtensen im Braunschweih' schess. Palaeontographica 1:169-173.

\section{PLATE 14}

1 Brunsvigella thoerensis (Bartenstein and Brand), (×90), holotype.

2a,b Brunsvigella thoerensis (Bartenstein and Brand) (juvenile), $(\times 120, \times 120)$, Sample 766A-46R-03; $122-125 \mathrm{~cm}$.

3a,b Psilocitharella kochii (Roemer), $(\times 130, \times 125)$, Sample 766A-46R-03; 122-125cm.

4a, b Brunsvigella thoerensis (Bartenstein and Brand), $(\times 45$, $\times 45$ ), Sample 766A-46R-03; 122-125cm.

5a,b Vaginulina petila Eicher and Worstell, $(\times 65, \times 65)$, Sample 766A-46R-03; $122-125 \mathrm{~cm}$.
6 Psilocitharella arguta (Reuss), $(\times 90)$, Sample 766A43R-02; 46-50cm.

7a,b Patellina subcretacea Cushman and Alexqander, $(\times 100$, $\times 95$ ), Sample 766A-33R-02; $15-18 \mathrm{~cm}$.

8a,b Patellina subcretacea Cushman and Alexander, $(\times 115$, $\times 110$ ), Sample 766A-40R-02; 46-50cm.

9a,b Spirillina minima Ehrenberg, $(\times 120, \times 120)$, Sample 766A-45R-02; 109-113cm. 


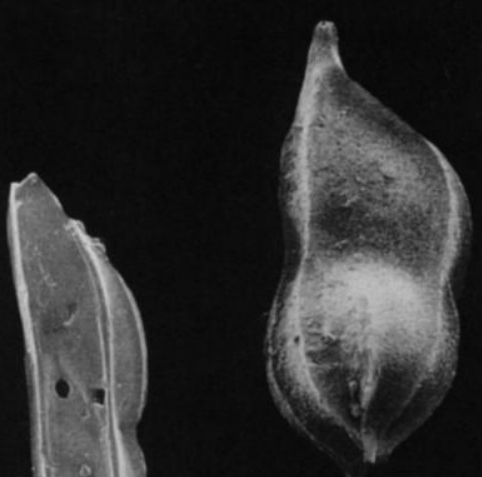

$2 a$

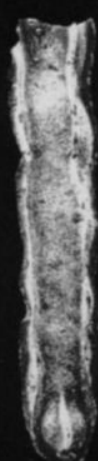

4 a

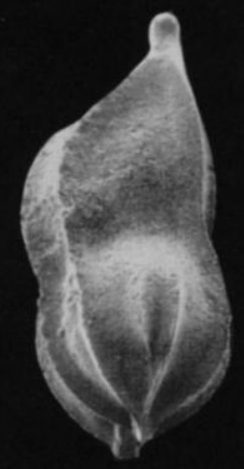

2b

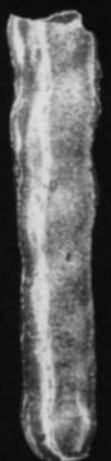

$4 \mathrm{~b}$

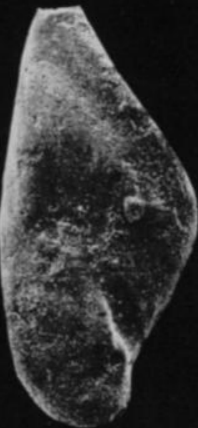

$3 a$

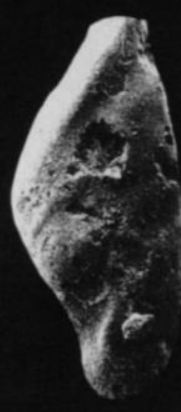

$3 \mathrm{~b}$

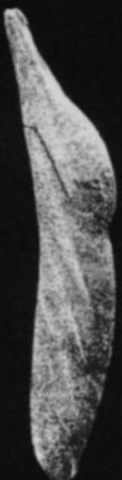

5 a

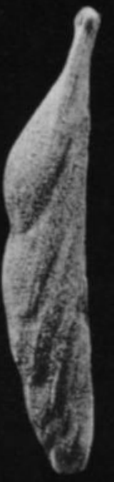

$5 \mathrm{~b}$

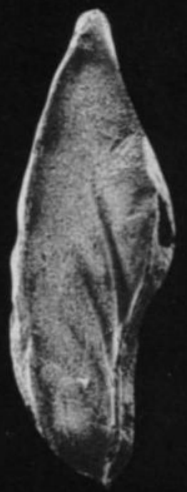

6

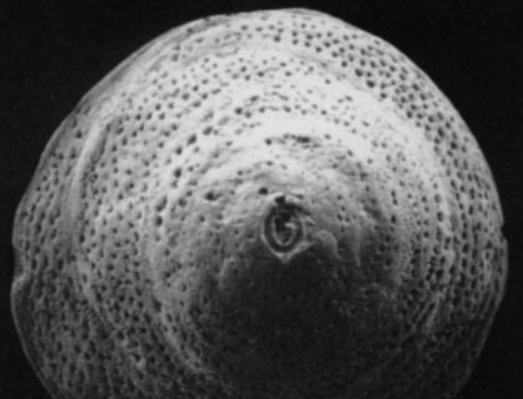

$7 \mathrm{a}$

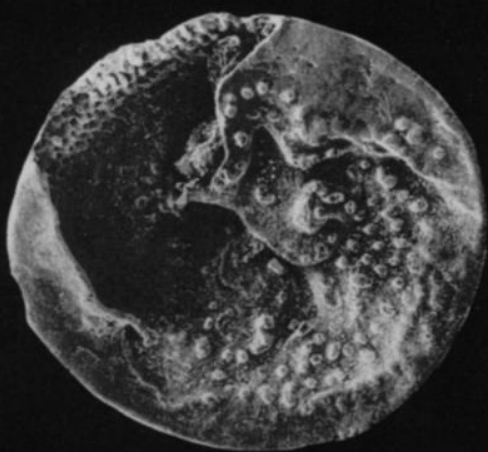

7 b

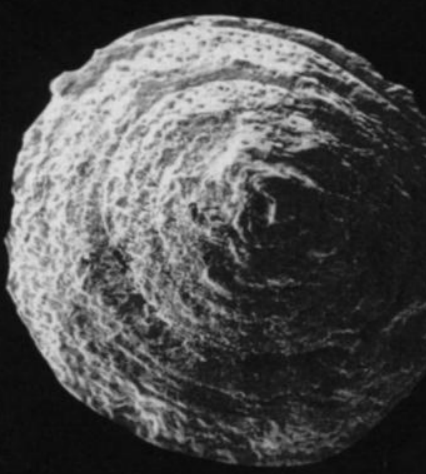

8 a

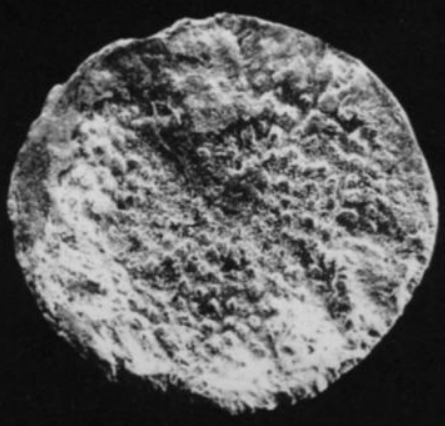

8 b

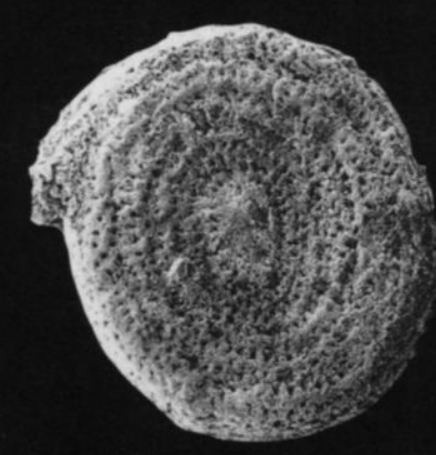

9 a

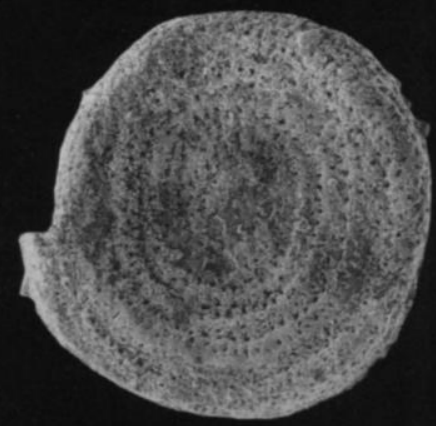

$9 b$ 
KUZNETSOVA, K. I., 1974. Benthonic Foraminifera, Upper Jurassic and Lower Cretaceous Deposits, Site 261. In: Veevers, J. J., Heirtzler, J. R. et al., Initial Reports of the Deep Sea Drilling Project, Volume 27:663-681. Washington, D.C.: U.S. Government Printing Office.

KUZNETSOVA, K. I. and SEIBOLD, I., 1977. Upper Jurassic and Lower Cretaceous Foraminifers. In: Lancelot, Y., Seibold, E. et al., Initial Reports of the Deep Sea Drilling Project, Volume 41:515-537. Washington, D.C.: U.S. Government Printing Office)

$\rightarrow$ LAMBERT, G. and SCHEIBNEROVÁ V., 1974. Albian Foraminifera of Zululand (South Africa) and Great Artesian Basin (Australia). Micropaleontology, 20:76-96.

LOEBLICH, A. R. and TAPPAN, H., 1987. Foraminiferal Genera and their Classification. New York: van Nostrand Reinhold, pp. 1-970, pl. 1-847.

LUDBROOK, N. H., 1966. Cretaceous biostratigraphy of the Great Artesian Basin in South Australia. Bulletin of the Geological Survey of South Australia, 40:1-223.

LUDDEN, J. N. and GRADSTEIN F. M. et al. 1990. Proceedings of the Ocean Drilling Program, Initial Reports, 123:1-716. College Station, TX: Ocean Drilling Program.

McNEIL, D. H. and CALDWELL, W. G. E., 1981. Cretaceous Rocks and their foraminifera in the Manitoba Escarpment. Geological Association of Canada, Special Paper 21:1-439.

MEYN, H. and VESPERMANN, J., 1994. Taxonomische Revision von Foraminiferen der Unterkreide SE-Niedersachsens nach Roemer (1839, 1841, 1842), Koch (1851) und Reuss (1863). Senckenbergiana lethaea 74(1/2):49-272

MICHAEL, E., 1967. Variations in the number of species of benthonic foraminifera in the Barrremian of Northwestern Germany. Palaeogeography, Palaeoclimatology, Palaeoecology, 4(4):287-303.

MICHAEL, E., 1974. Zur Paökologie und Faunenführung im westlichen Bereich des norddeutschen Unterkreide-Meeres. Geologisches Jahrbuch, A/9:3-67.

MONTAGU, G., 1803. Testacea Britannica or History of British Shells, Marine, Land and Freshwater, Including Most Minute. J. S. Hollis, Romsey, England.
MOULLADE, M., 1966. Etude stratigraphique et micropaléontologique du Crétacé inférieur de la "Fosse Vocontienne". Documents des Laboratoires de Géologie de la Faculté des Sciences de Lyon, vol. 15(1-2):1-369.

1974. Zones de Foraminifères du Crétacé inférieur mésogéen. Comptes-Rendus de l'Académie des Sciences, Paris, t. 278, série d:18131816.

MOULLADE, M., 1979. Les Foraminifères du Valanginien Hypostratotypique. In: Busnardo, R., Thieuloy, J. P. and Moullade, M., Hypostratotype Mesogéen de l'Étage Valanginien (Sud-Est de la France). Les Stratotypes Français, vol. 6. Editions du C.R.N.S., pp. 110-126.

1984. Intérêt des petits foraminifères benthiques "profonds"pour la stratigraphie et l' analyse des paléoenvironnements océaniques mésozoiques. In: Oertli, H. J., Ed., Benthos '83, 2nd International Symposium on Benthic Foraminifera (Pau, April 1983), Elf Aquitaine, Esso REP and Total CFP, Pau and Bordeaux, pp. 429-464.

MOULLADE, M. and GUÉRIN, S., 1982. Le problème des relations de l'Atlantique Sud et de l'Atlantique Central au Crétacé moyen: nouvelles données microfauniques d'après les forages D.S.D.P. Bulletin de la Société géologique de France (7), t. 24, no. 3:511-517.

MYATLYUK, E. V., 1980. Stratigraphy of Berriasian strata of the Precaucasus (on the data from foraminiferal fauna). In: Mikrofauna; biostratigrafiya Fanerozoya neftegazonosnykh rayonov SSSR (Sbornik Trudor). Trudy Vsesoyuznogo Ordena Trudovogo Krasnogo Znaeni Neftyanogo Naucho-issledovatel' skogo Geologorazvedochnogo Instituta (VNIGRI), pp. 80-100 (in Russian).

MYATLYUK, E. V. and VASILENKO, V.P., 1988. Atlas of Lower Cretaceous foraminiferal markers around the Caspian Depression, Mangyshlak and Usturt Peninsulas. Leningrad: Nedra, pp. 1-178, pl. 1-72, (in Russian).

$\rightarrow$ NAUSS, A. W., 1947. Cretacous microfossils of the Vermilion area, Alberta. Journal of Palaeontology, 21(4):329-343.

NEAGU, T., 1975. Monographie de la faune des Foraminifères éocrétacés du couloir de Dimboviciora, de Codlea et des Monts (Persani), (Couches de Carhaga). Mémoires de l'Institut de Géologique et Géophysique, 25:1141.

1990. Gerochammina n. g. and related genera from the upper Cretaceous flysch-type benthic foraminiferal fauna, Eastern Carpathians, Rumania. In: Hemleben, C., Kaminski, M. A., Kuhnt, W. and Scott, D.

\section{PLATE 15}

la,b Gavelinella sigmoicosta? (Ten Dam), $(\times 190, \times 190)$, Sample 766A-29R-03; 54-55cm.

2a,b Reinholdella hofkeri (Bartenstein and Brand), $(\times 150$, $\times 145$ ), Sample 766A-40R-01; 84-88cm.

3a,b Gavelinella barremiana Bettenstaedt, $(\times 200, \times 195)$, Sample 766A-28R-03; 116-120cm.

4a,b Globulina lacrima (Reuss), $(\times 140, \times 150)$, Sample 766A-46R-03; 122-125cm.

5a,b Globulina lacrima (Reuss), $(\times 130,135)$, Sample 766A32R-05; 5-8cm. 6a,b Globulina bucculenta (Berthelin), $(\times 100, \times 100)$, Sample 766A-32R-05; 5-8cm.

7a,b Globulina prisca Reuss, $(\times 120, \times 120)$, Sample 766A40R-01; 84-88cm.

8 Globulina prisca Reuss, $(\times 70)$, Sample 766A-32R-05; $5-8 \mathrm{~cm}$.

9 Globulina prisca Reuss, (×95), Sample 766A-32R-05; $5-8 \mathrm{~cm}$.

10 Pyrulina cylindroides (Roemer), (×85), Sample 766A47R-04; 114-119cm. 


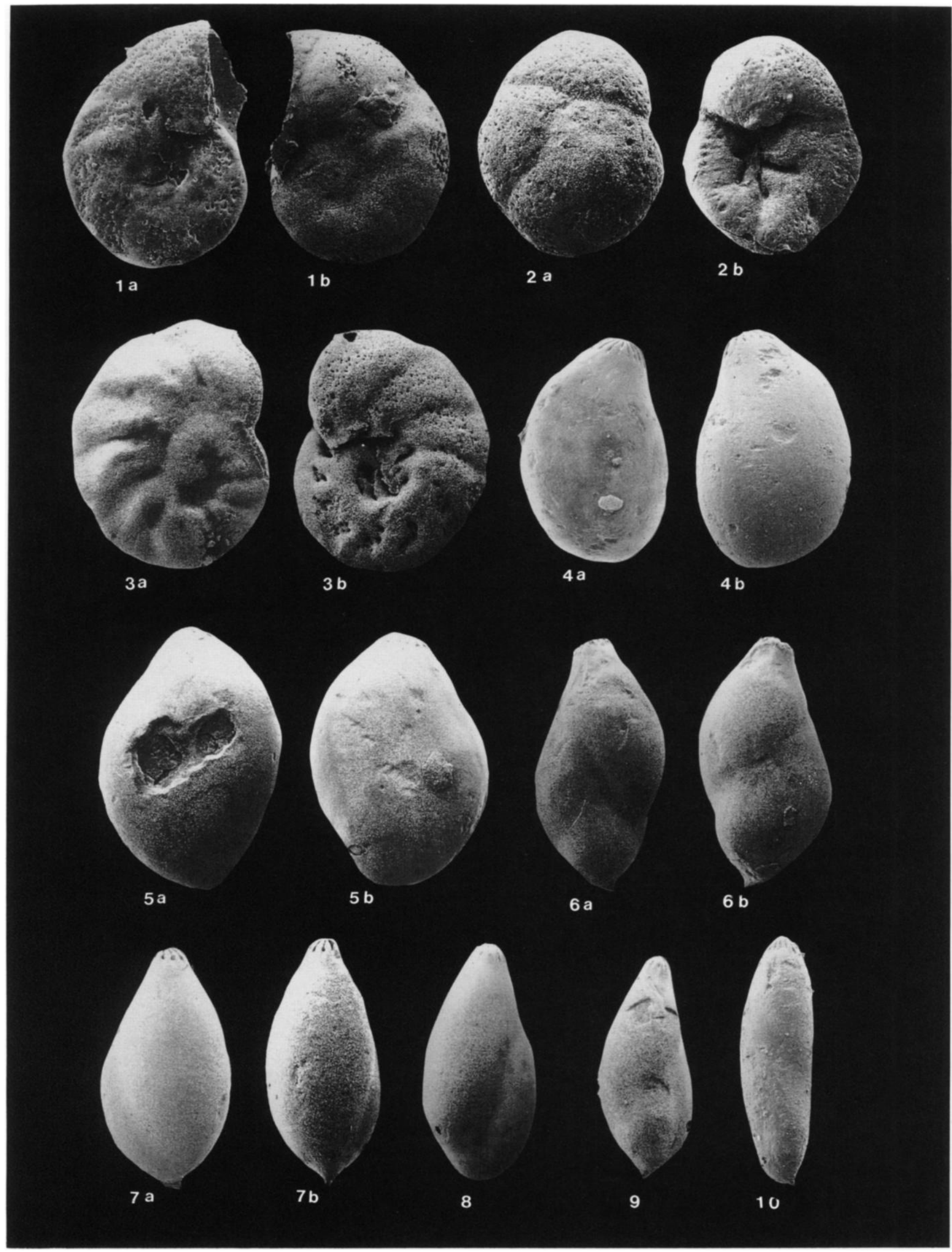


B., Eds., Palaeoecology, Biostratigraphy, Palaeoceanography and Taxonomy of Agglutinated foraminifera. NATO ASI Series C 327, Kluwer Academic Publishers, pp. 245-265.

d'ORBIGNY A., 1826, Tableau methodique de la classe des Céphalopodes. Annales des Sciences Naturelles, 7:245-314.

1840. Mémoire sur les Foraminiferes de la craie blanche du bassin de Paris. Mémoires de la Société Geologique de France 4:1-51.

POWELL, C. McA., ROOTS, S. R. and VEEVERS, J. J., 1988. Pre-break up continental extension in East Gondwanaland and the early opening of the eastern Indian ocean. Tectonophysics, 155:261-283.

REUSS, A. E., 1845. Die Versteinerungen der böhmischen Kreideformation. Abth. 1 Teil 2:1-148.

1850. Neue Foraminiferen aus dem Schichten des österreischischen Tertiärbeckens Denkschriften der Kaiserlichen Akademie der Wissenschaften, Mathematisch-Naturwissenschaftliche Classe 1:365-390.

1851. Die Foraminiferen und Entomostraceen des Kreidemergels von Lomberg. Abhandlungen Naturwissenschaften, 4(1):17-52.

, 1858. Über die Foraminiferen von Pietzpuhl. Zeitschrift der Deutschen Geologischen Gesellschaft, 10:433-438.

, 1860. Die Foraminiferen der westphälischen Kreideformation. Akademie der Wissenschaften zu Wien, Mathematische-Naturwissenschaftliche Klasse, Sitzungsberichte, 40:147-238.

1863. Die Foraminiferen des norddeutschen Hils and Gault. Sitzungberichte der Mathematische-Naturwissenschaftliche Klasse der Kayserliche Akademie der Wissenschaften, Wien, 46:5-100.

RICCARDI, A. C., 1988. The Cretaceous system of southern South America. The Geological Society of America, Memoir 168:41-73.

RIEGRAF, W., 1989. Benthonische Schelf-foraminiferen aus dem Valanginium-Hauterivium (Unterkreide) des Indischen Ozeans südwestlich
Madagaskar (Deep Sea Drilling Project Leg 25, Site 249). Geologische Rundschau, 78(3):1047-1061.

RIEGRAF, W. and LUTERBACHER, H., 1989a. Benthonische Foraminiferen aus der Unterkreide des "Deep Sea Drilling Project" (Leg 1-79). Geologische Rundschau, 78(3):1063-1120.

1989b. Oberjura-Foraminiferen aus dem Nord- und Südatlantik (Deep Sea Drilling Project 1-79). Geologische Rundschau, 78(3):9991045.

ROEMER, F., 1838. Die Cephalopoden des Nord-Deutschen tertiären Meersandes. Neues Jahrbuch für Mineralogie, Geognosie, Geologie und Petrefakten-Kunde, 381-394.

1839. Die Versteinerungen des norddeutschen Oolithen-Gebirges. Hannover, 1-145.

1841. Die Versteinerungen des norddeutschen Kreidegebirges. Hannover, $1-145$

1842. Neue Kreide-Foraminiferen. Neues Jahrbuch für Mineralogie, Geognosie, Geologie und Petrefakten-Kunde, 272-273.

SCHACKO, G., 1892. Beitrag über Foraminiferen aus dem Cenoman-Kreide von Moltzow in Mecklenburg. Verein der Freunde der Naturgeschichte in Mecklenberg. Archiv, 50:161-168.

SCHEIBNEROVÁ, V., 1971a. The Great Artesian Basin, a type area of the Austral Biogeoprovince of the Southern Hemisphere equivalent to the Boreal Biogeoprovince of the Northern Hemisphere. Proceedings of the Second Planktonic Conference, Roma 1970:1129-1138.

$\rightarrow-, 1971 \mathrm{~b}$. Lingulogavelinella (foramminifera) in the Cretaceous of the Great Artesian Basin, Australia. Micropaleontology, 17, (1):109-116.

1972. Some interesting foraminifera from the Cretaceous of the Great Artesian basin, Australia, Micropaleontology, 18, (2):212-222.

PLATE 16

la,b Eoguttulina ichnusae (Dieni and Massari), $(\times 160)$, Sample 766A-46R-03; 122-125cm.

2 Oolina cf. sulcata (Walker and Jacob), $(\times 145)$, Sample 766A-44R-05; 102-106cm.

3 Oolina sulcata (Walker and Jacob), $(\times 155)$, Sample 766A-47R-01; 98-103cm.

4 Oolina laevis (Montagu), $(\times 160)$, Sample 766A-34R$01 ; 70-74 \mathrm{~cm}$.

5 Oolina caudata d'Orbigny, $(\times 100)$, Sample 766A-34R$01 ; 122-125 \mathrm{~cm}$.

6 Oolina aff. oxystoma (Reuss), $(\times 170)$, Sample 766A48R-04; 51-54cm.

7 Ramulina sp., $(\times 110)$, Sample 766A-43R-02; 46-50cm.

$8 \quad$ Ramulina sp., (×65), Sample 766A-33R-02; 15-18cm.
9 Ramulina aculatea Wright, $(\times 120)$, Sample 766A-44R$03 ; 47-52 \mathrm{~cm}$

10 Ramulina aculatea Wright, $(\times 120)$, Sample 766A-46R$04 ; 105-110 \mathrm{~cm}$.

11 Ramulina aculatea Wright, $(\times 60)$, Sample 766A-39R$01 ; 47-51 \mathrm{~cm}$

12 Ramulina sp., $(\times 100)$, Sample 766A-46R-03; 122$125 \mathrm{~cm}$.

13 Palaeopolymorphina sp. 1, (×90), Sample 766A-37R$01 ; 29-33 \mathrm{~cm}$.

14 Palaeopolymorphina sp. 1, (×55), Sample 766A-47R$04 ; 114-119 \mathrm{~cm}$.

15a,b Palaeopolymorphina sp. $1,(\times 100, \times 105)$, Sample 766A-46R-03; $122-125 \mathrm{~cm}$. 


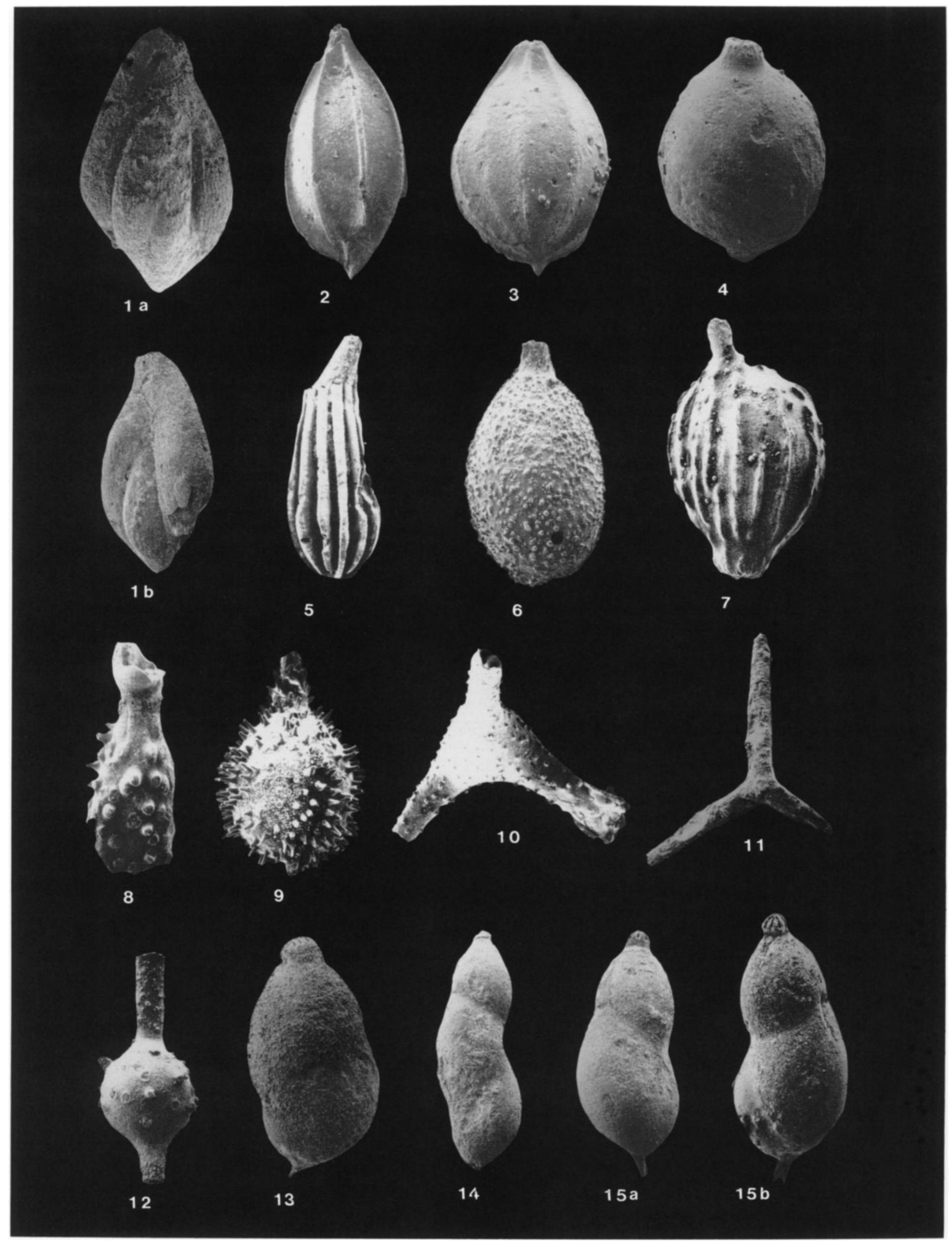


1973. A comparison of the Austral and Boreal Lower Cretaceous foraminiferal and ostracodal assemblages. In: Casey, R. and Rawson, P. F., Eds., Geological journal special issue no. 5, The Boreal Lower Cretaceous. Liverpool: Seelhouse Press, pp. 407-414.

1974a. The ecology of Scutuloris and other important genera from the Early Cretaceous of the Great Artesian Basin (Australia). Revista Española de Micropalaeontologia, VI, nùm. 2:229-255.

1974b. Aptian-Albian Benthonic Foraminifera from DSDP Leg 27, Sites 259, 260 and 263, Eastern Indian Ocean. In: Veevers, J. J. Heirtzler, J. R. et al. 1974. Initial Reports of the Deep Sea Drilling Project, 27:697-741. Washington, D.C.: U.S.Government Printing Office.

1976. Cretaceous Foraminifera of the Great Australian Basin. New South Wales Geological Survey Memoirs on Palaeontology, $\mathrm{N}^{\circ}$ 17:1-265.

1977. Synthesis of the Cretaceous benthonic foraminifera recovered by the Deep Sea Drilling Project in the Indian Ocean. In: Heirtzler, J. R., Bolli, H. M., Davies, T. A., Saunders, J. B. and Sclater, J. G., Eds., Indian Ocean Geology and Biostratigraphy Studies following Deep Sea Drilling Legs 22-29. Washington, D.C.: American Geophysical Union, pp. 585597.

1978. Austral Foraminifera and their importance for Cretaceous biostratigraphy and paleogeography. Actes du $\mathrm{VI}^{\mathrm{e}}$ Colloque Africain de Micropaléontologie (Tunis, Mars 1974). Annales des Mines et de la Géologie, $n^{\circ} 28$, Tome 2:153-160.

SIGAL, J., 1952. Aperçu stratigraphique sur la micropaléontologie du Crétacé. Alger 19th International Geological Congress, Monographies Régionales, 1st series, Algérie, (26):1-47.

SIGAL, J., GREKOFF, N., SINGH, N. P., CANON, A. and ERNST, M., 1970. Stratigraphie-Sur l'âge et les affinités "gondwaniennes" des microfaunes malgaches, indiennes et chiliennes au sommet du Jurassique et à la base du Crétacé. Comptes-Rendus de l'Académie des Sciences, Paris, t. 271, série d:24-27.

SISSINGH, W., 1977. Biostratigraphy of Cretaceous Calcareous Nannoplankton. Geologie en Mijnbouw, 56:37-65.

SLITER, W. V., 1977. Cretaceous Benthic Foraminifers from the western south Atlantic Leg 39, Deep Sea Drilling Project. In: Supko, P. R. and Perch-Nielsen, K. et al., Initial Reports of the Deep Sea Drilling Project, 39:657-698. Washington, D.C.: U.S. Government Printing Office.
1980. Mesozoic Foraminifers and deep-sea benthic environments from Deep Sea Drilling Project Sites 415 and 416, Eastern North Atlantic. In: Lancelot, Y. Winterer, E. L. et al., Initial reports of the Deep Sea Drilling Project, Volume 50: 353-428. Washington, D.C.: U.S. Government Printing Office

TAPPAN, H., 1957. New Cretaceous index foraminifera from northern Alaska. In: Loeblich, A. R. and collaborators. Studies in Foraminifera. Bulletin of the United States National Museum, 215:201-222.

1962. Foraminifera from the Arctic Slope of Alaska. Part 3, Cretaceous Foraminifera. Geological Survey Professional Paper 236-C, United States Department of the Interior, pp. 1-209, pl. 29-58.

TEN DAM, A., 1946. Arenaceous Foraminifera and Lagenidae from the Neocomian of the Netherlands. Journal of Palaeontology, 20(6):570-577.

TEN DAM, A., 1948. Foraminifera from the middle Neocomian of the Netherlands. Journal of Palaeontology, 22(1):187-188.

TERQUEM, O., 1862. Recherches sur les Foraminiferes de l' étage moyen et de l' étage inférieur du Lias. Mémoires de l' Académie Impériale de Metz, 42(1860-1861):415-416.

WALKER, G. and JACOB, E., 1798. In: Kanmacher, F., Adam's Essays on the microscope, Ed. 2. London: Dillon and Keating.

WEIDICH, K. F., 1990. Die kalkalpine Unterkreide und ihre Foraminiferenfauna. Zitteliana 17, Abhandlungen der bayerischen Staatssammlung für Paläontologie und historische Geologie, 1-312, pl. 1-62.

WICKENDEN, R. T. D., 1932. New species of foraminifera from the Upper Cretaceous of the prairie provinces. Transactions of the Royal Society of Canada, ser. 3, sec. 4, 26:85-91.

WISNIOWSKI, T., 1890. Mikrofauna ilów ornatowych okolicy Krakowa. Czçsc. I. Otwornice górnego keloweju w Grojcu. Denkschriften der Akademie der Wissenschaften, Krakau, math.-naturw. Abt., 17:81-142.

ZEDLER, B., 1961. Stratigraphische Verbreitung und Phylogenie von Foraminiferen des nordeutschen Oberhauterive. Paläontologishe Zeitschrift, 35(1/2):28-61.

Manuscript received April 5, 1994

Manuscript accepted November 30, 1994 